\title{
Selected Lessons Learned in Space Shuttle Orbiter Propulsion and Power Subsystems
}

\author{
Francisco J. Hernandez ${ }^{1}$, Hugo Martinez ${ }^{2}$, Abigail Ryan ${ }^{3}$, Shayne Westover ${ }^{4}$, and Frank Davies ${ }^{5}$ \\ NASA/Johnson Space Center, Houston, TX 77058
}

Over its 30 years of space flight history, plus the nearly 10 years of design, development test and evaluation, the Space Shuttle Orbiter is full of lessons learned in all of its numerous and complex subsystems. In the current paper, only selected lessons learned in the areas of the Orbiter propulsion and power subsystems will be described. The particular Orbiter subsystems include: Auxiliary Power Unit (APU), Hydraulics and Water Spray Boiler (WSB), Mechanical Flight Controls, Main Propulsion System (MPS), Fuel Cells and Power Reactant and Storage Devices (PRSD), Orbital Maneuvering System (OMS), Reaction Control System (RCS), Electrical Power Distribution (EPDC), electrical wiring and pyrotechnics. Given the complexity and extensive history of each of these subsystems, and the limited scope of this paper, it is impossible to include most of the lessons learned; instead the attempt will be to present a selected few or "key" lessons, in the judgment of the authors. Each subsystem is presented separate, beginning with an overview of the hardware and their function, a short description of a few historical problems and their lessons, followed by a more comprehensive table listing of the major subsystem problems and lessons. These tables serve as a quick reference for lessons learned in each subsystem. In addition, this paper will establish common lessons across subsystems as well as concentrate on those lessons which are deemed to have the highest applicability to future space flight programs.

\section{Acronym List}

$\begin{array}{ll}A B C D & =\text { Adiabatic Bubble Compression Detonation } \\ A L T & =\text { Approach and Landing Test } \\ A P U & =\text { Auxiliary Power Unit } \\ A T P & =\text { Acceptance Test Procedure } \\ B F & =\text { Body Flap } \\ B S T R A & =\text { Ball-Strut Tie Rod Assembly } \\ C O P V & =\text { Composite Overwrapped Pressure Vessel } \\ C B & =\text { Circuit Breaker } \\ E C O & =\text { Engine Cut-off (System) } \\ E P D C & =\text { Electrical Power Distribution and Control } \\ E T & =\text { External Tank } \\ E V A & =\text { Extra-vehicular Activity } \\ F C S & =\text { Flight Control System } \\ F C M S & =\text { Fuel Cell single-cell Monitoring System } \\ F D A & =\text { Fault Detection and Annunciation } \\ F O R P & =\text { Fuel/Oxidizer Reaction Products } \\ G G & =\text { Gas Generator } \\ G G V M & =\text { Gas Generator Valve Module }\end{array}$

${ }^{1}$ Deputy Division Chief Engineer for Orbiter Power and Propulsion Systems and NASA Subsystem Engineer (NSE) for APU, Hydraulic and MFC, NASA JSC, 2101 NASA Parkway/EP. AIAA Member.

2 NASA Subsystem Engineer for Orbiter MPS, NASA JSC, 2101 NASA Parkway/EP. AIAA Member.

${ }^{3}$ NASA Subsystem Engineer for Orbiter Fuel Cells and PRSD, NASA JSC, 2101 NASA Parkway/EP. AIAA Member.

${ }^{4}$ NASA Subsystem Engineer for Orbiter OMS and RCS, NASA JSC, 2101 NASA Parkway/EP. AIAA Member.

${ }^{5}$ NASA Subsystem Engineer for Orbiter EPDC, NASA JSC, 2101 NASA Parkway/EP. 


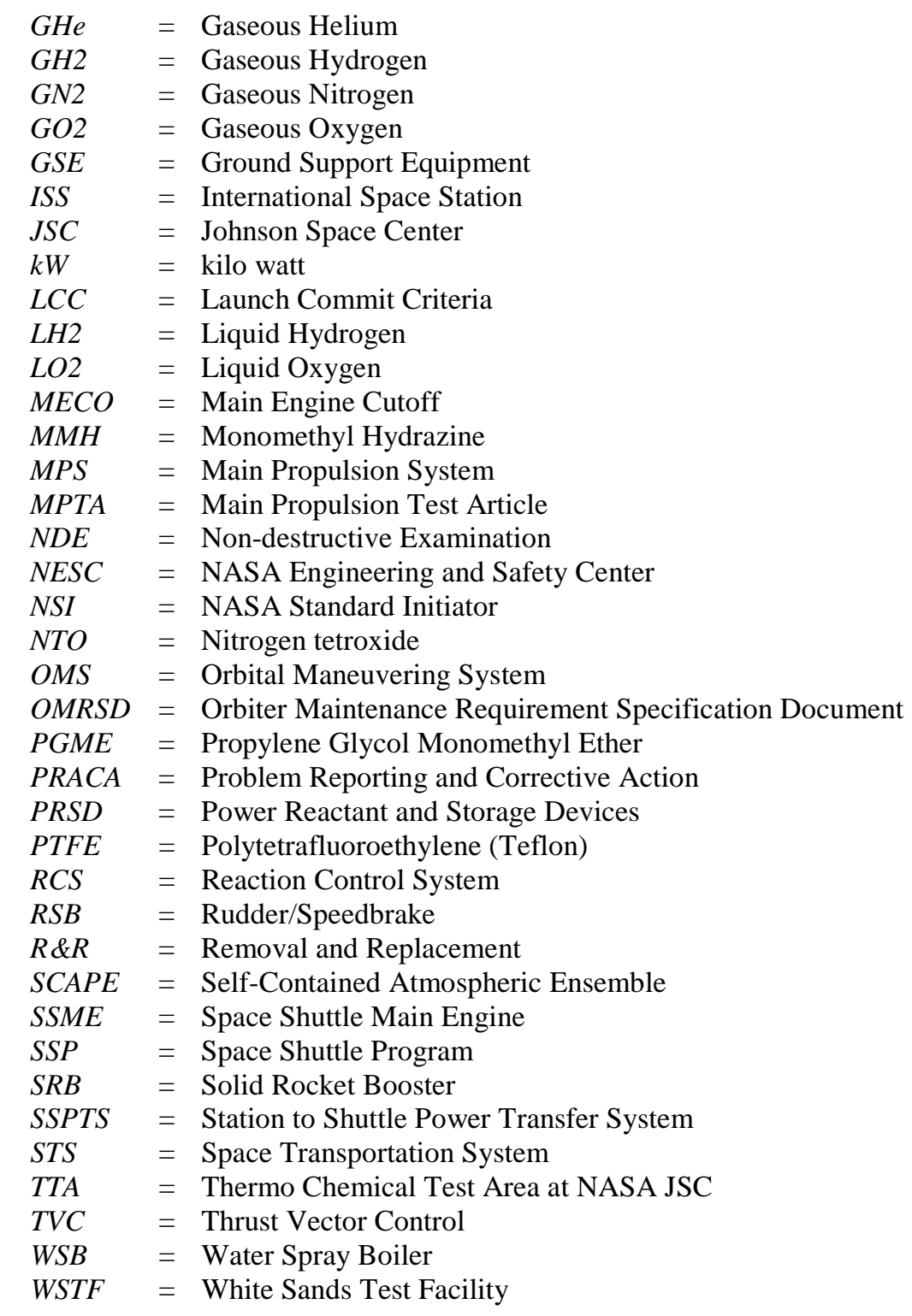

\section{Introduction}

brief description of each of the Orbiter subsystem will be provided, followed by selected historical events that shed some important lessons. A lesson learned summary table is provided at the end of each subsystem section for quick reference. Given the complexity and extensive history of each of these Orbiter subsystems, and the limited scope of this paper, the attempt is not to include all of the lessons learned; instead it will be to present a selected few or highlight lessons, in the judgment of the authors. Historical hardware anomalies or ones that remained as unexplained anomalies (UA), i.e., no root cause was determined, and provided little or no lessons, are not included. Detailed description of all historical Shuttle subsystem anomalies can be found in the SSP PRACA database. In addition, no attempt is made to explain detailed design solutions to specific hardware problems encountered over the years; rather the intent is to concentrate on general practical lessons, lessons learned that are common across subsystems as well as to concentrate on those lessons which are deemed to have the highest applicability to future space flight programs.

\section{Auxiliary Power Units (APU) subsystem:}

The Space Shuttle Orbiter has 3 independent monopropellant grade hydrazine fueled APUs, which through catalytic decomposition, transmit the mechanical power to drive the 3 hydraulic pumps. These, in turn, provide 
hydraulic power to the flight control system actuators, main engine hydraulic valves and auxiliary end effectors. The APU subsystem consists of the APU unit, the hydrazine fuel tanks and distribution lines, injector water cooling system, drain system, exhaust duct and APU controller (Fig. 1-2). As with any new complex program, the large majority of the lessons learned occurred early in its history; from the development and qualification testing through the Approach and Landing Test (ALT) and early orbital flights.

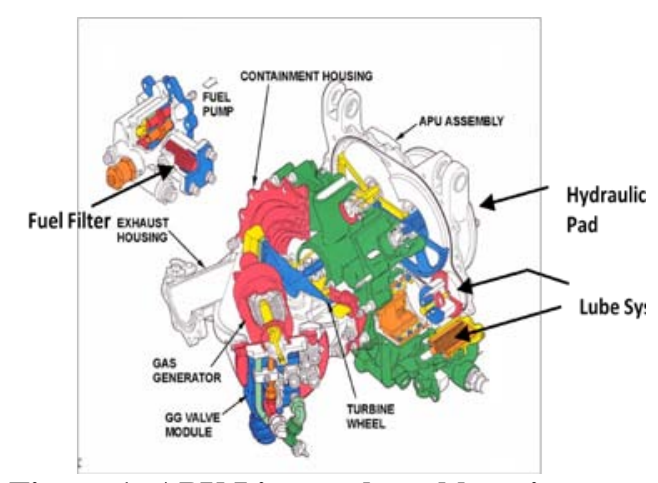

Figure 1: APU Line-replaceable unit

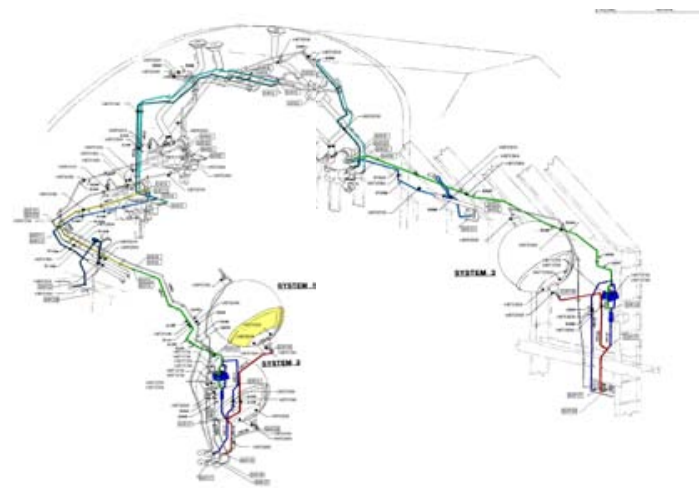

Figure 2: APU Subsystem in Orbiter aft compartment

The original APU procurement specification on which the contract was bid called for a 250 hour (hr) operating unit, however, during the development phase it was quickly realized that the capability was not there and it could only operate reliably for approximately $20 \mathrm{hrs,} \mathrm{with} \mathrm{extension} \mathrm{to} 40 \mathrm{hrs}$ through periodic maintenance. In the 1992 timeframe, a goal was established of $75 \mathrm{hrs,} \mathrm{which} \mathrm{was} \mathrm{achieved} \mathrm{after} \mathrm{the} \mathrm{upgrade} \mathrm{from} \mathrm{the} \mathrm{baseline} \mathrm{to} \mathrm{the} \mathrm{Improved}$ APU (IAPU) design.

There were several design problems during the early development of the APUs. Some of the major issues included: poor fuel pump performance and lubrication, turbine wheel blade and shroud cracking, gas generator life and hot-start capability, gearbox accumulator performance, turbine housing life/cracks, turbine failure containment, controller manufacturing, and Gas Generator Valve Module (GGVM) control valve seat life/cracks. Lessons learned from these development challenges can be found in Ref. 1. One example of this includes a change in the water cleaning process for the original GGVM. As part of a process improvement, a change was made to utilize de-ionized water. It turns out that this water caused leaching of the cobalt binder inside of the tungsten carbide seats, which inturn resulted in the valve seats cracking after installation in APUs. This valve seat cracking was the cause of a launch scrub on STS-31. Lesson here is to be extra vigilant when making process changes to critical hardware since changes can sometimes bring unintended consequences; in the case of the old APU GGVM, it turns out to be the wrong choice.

The APU fuel tank isolation valve underwent several design changes over the life of the Orbiter Program. The original valve included a bellows design. During APU system level ground testing in the early 1970's, the valve suffered a catastrophic detonation failure. Failure analysis concluded that the surge pressures created by the APU GGVM were high and frequent $(1.5$ to $3 \mathrm{~Hz})$ that the bellows failed due to fatigue. The lesson here is that a bellows design is not compatible with a fluid system that experiences frequent, high ( 720 psia) surge pressures. After several re-design iterations over the years, a new valve from MOOG Corporation was implemented in 1992, which eliminated all the previous critical design shortcomings.

An explosive failure during qualification testing at the NASA JSC Thermo Chemical Test Area (TTA) vacuum chamber provided several lessons. This failure occurred during a hot restart attempt as a result of adiabatic bubble compression detonation (ABCD) at high temperatures. This test highlighted the importance of testing the complete integrated system in a vacuum and thermally representative environment, similar to those encountered during flight. This testing also helped define the cool down rates of the APU and showed that the APU could not be immediately restarted after shutdown without performing an actively cooled hot restart; uncovering a certification requirement shortcoming. In another development test a detonation occurred in the fuel pump seal cavity drain area between the fuel pump and gearbox. The carbon shaft seal was found to be fabricated from the incorrect material which deteriorated allowing metal to metal contact. This permitted the metal seal carrier to contact the rotating metal shaft 
seal. This metal to metal contact developed a heat source of sufficient magnitude to ignite the air and hydrazine vapors within the seal cavity. The APU fuel pump was later redesigned as part of the Improved APU (IAPU) so as to avoid the possibility of any metal-to-metal contact even if the carbon shaft seal were to fail.

During OV-101 ALT second manned Captive Active flight, liquid hydrazine discharged overboard from the APU drain line and was re-ingested into the aft fuselage. Approximately one third of the aft structure was covered with hydrazine which resulted in significant damaged wiring and insulation (e.g., Kapton). The root cause was the failure of the seal bellows of the fuel pump. It was later replaced with a face seal using an elastomeric secondary seal. In addition, the seal cavity drain port was relocated away from vent doors and all aft access doors were sealed with silicon gaskets. A lesson for future vehicles is to avoid placing fuel drain ports near access doors or assure adequate seals against propellant re-ingestion into vehicle compartments.

During the first mission, STS-1, both APU \#2 gas generators failed due to argon gas leak at a weld in the GG heater common cavity case. A crack in a weld allowed the argon gas to escape. Loss of the heat transfer gas causes the calrod heater element to overheat and melt at the break point. During qualification testing, these heaters had passed an evacuated test. It was not a long-term steady-state test and primarily consisted of cycling the heaters multiple times. Subsequent to the flight, all heater cases were functionally tested under vacuum and the resistance measured to monitor for any signs of leakage. Long term redesign consisted of separating the heaters into two individual cavities and performing functional vacuum leak tests as part of the acceptance process. This event demonstrated the need to verify that redundant elements are truly independent and improved inspection techniques and checkouts to verify critical systems.

Also during STS-1 and STS-2, there were indications of bubbles trapped in the fuel feedline which resulted in abnormal GG pressures (bubbles continued to be observed until introduction of the Improved APU on STS-45). Gas bubble trapped inside the fuel lines can be adiabatically compressed to raise the temperature to detonation level, i.e., adiabatic bubble compression detonation (ABCD). An explosion during qualification testing had been attributed to this cause. Excessive dwell time at temperatures above $200^{\circ} \mathrm{F}$ caused fuel decomposition and bubble formation. As a result of this concern, great care was established at KSC to avoid introducing gas during fuel loading operations, e.g., vacuum fill. In addition, due to the normal decomposition of hydrazine in the fuel system at ambient temperatures, attempts were made to reduce the elapsed time between fuel servicing operations and launch. Low bubble point hydrazine filters also helped avoid bubble formation and abnormal gas generator pressures.

During STS-2 pre-launch period, a launch scrub occurred due to APU \#1 and \#3 indicating high lubrication oil outlet pressures. The lube oil filter and drain passage were determined to be plugged with a pentaerythritol wax formation from the mixing of hydrazine and oil within the APU gearbox. Procedures were developed to flush the gearbox and replace the oil and filters. A redesign of the APU seal cavity drain system to eliminate the common seal between the oil and fuel resolved this issue. This event provided the following lessons: a re-design to solve a design flaw is more cost effective than continuous maintenance as a solution to an on-going problem, and compatibility of fluids must be well understood even if they are sealed from each other.

Another problem that occurred during the early flights happened during STS-9 landing phase where two APUs suffered an explosion due to an injector tube crack which took everyone by surprise (Fig. 3). This required extensive research into the cause of the origin which was found to be stress corrosion cracking of the injector stem; primarily due to the environment to which the APU is exposed from the hydrazine decomposition products. All the qualification testing preceding STS-9 had not taken into account the long "down time" or exposure time between operation cycles. In order to make the most efficient use of time during qualification testing, the APU was operated for a specified number of hours to qualify it for the same amount of operational time, not taking into account any down time between flights. This was found to be a significant factor for this failure. Hence, as a lesson from this failure, the IAPU qualification program was designed so that a segment of the testing included the long down time between missions at KSC (approximately 3-4 months); while simulating the highly humid and salt corrosive Florida environment. 

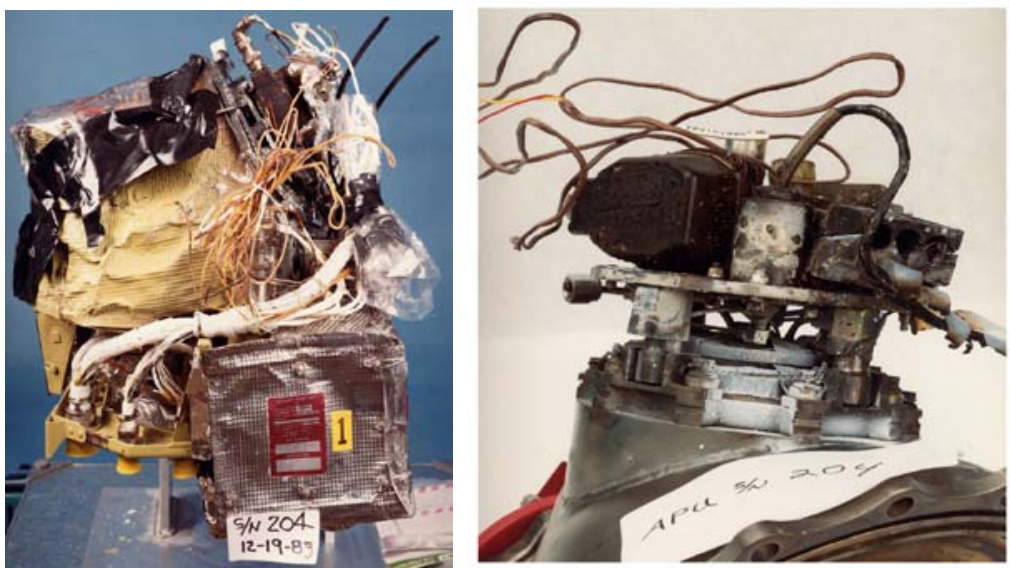

Figure 3: Damaged APU from STS-9 detonation, showing approximate location of cracked injector stem and hydrazine leak

The discovery of fatigue cracks (roots and tips) in the original APU turbine disk blades led to the re-design of this component. Eight cases of blade cracking occurred on development units, qualification units as well as production flown units. Figure 4 shows a close-up of a fractured blade found during a routine overhaul inspection of APU\#3 in 1987, removed from OV-104. When blades fail, loose pieces can cause extensive blade damage, high vibration, leading to shaft failure and possible uncontained wheel rupture. In all cases wheel crack damage was limited to blades and shroud, with all incidents being contained/safe, although some resulted in significantly increased vibration levels and noise. The investigation concluded that the cracks were due to high cycle fatigue, with some evidence of environmental interaction and blade rub. A redesigned 75-hour APU turbine made from Rene 41, a Nickel-based high temperature and strength alloy, was implemented as part of the IAPU in 1992. Some lessons from this investigation as they apply to turbine wheel design, manufacturing and maintenance were: to incorporate a full-width shroud that supports the complete blade profile, perform periodic NDE (e.g., mapping via dye penetrant inspections), reduce the number of grinding operations (without a stress relieve) after the final heat treatment to prevent imparting residual stresses, use a controlled heating method (no use of torch), and specifying the weld inspection criteria after the finish is completed.

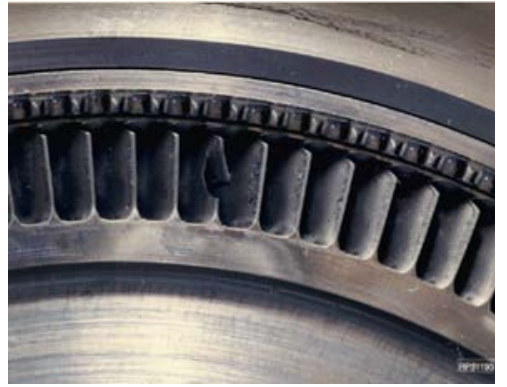

Figure 4: Close-up of fractured APU turbine blade

Just prior to STS-62, a rain shower at KSC resulted in some flooding within the aft compartment. The visible water was removed and some effort was taken to dry the insulation prior to flight. However, some residual water was trapped within the APU insulation. In-flight vacuum induced flash freezing of this water in the insulation caused hydrazine in the fuel line to freeze, resulting in fuel blockage. This is a failure mode nobody had ever considered or evaluated before and was induced by factors completely outside of the APU subsystem or vehicle. A lesson from this event is that if there is any indication of a water/fluid intrusion, assume that it could be entrapped under insulation and check. Areas should be identified within the vehicle where water may be trapped. Prior to rollout, vehicle vent doors and access doors that are vulnerable to rain intrusion should be closed. Insulation should be designed to avoid trapping water; e.g., drain holes.

During STS-79 ascent an APU had an unexpected underspeed shutdown post-MECO due to a speed sensor failure. Destructive analysis of Magnetic Pickup Unit (MPU) \#2 found an internal broken wire. However, a single speed failure sensor should not have caused an APU shutdown. Review of the wiring diagrams showed that MPUs $\# 1$ and \#2 were installed with reversed polarity relative to the wiring specifications. The problem had not shown up in testing at the vendor because the wiring was different at the test facility; in fact, the test system was re-configured to match the incorrect production unit wiring. The wiring problem occurred when a new improved APU controller design was put in place for all vehicles before STS-51 flew in 1993. As a result of the mis-wiring, less redundancy existed than what was intended. It is interesting to note that the original baseline APU controller was not sensitive to mis-wiring since each MPU was dedicated to a single function with no voting logic. Multiple lessons can be drawn from this, such as: sometimes hardware upgrades bring unexpected sensitivities or consequences, ground test 
hardware should have similar configuration as flown hardware, and having consistent callouts across all levels of hardware drawings.

After STS-73 landed and the APUs were shut down, a decrease in fuel pump inlet pressure was observed with a corresponding increase in seal cavity drain pressure. Examination of the fuel pump showed large amounts of apiezon grease at the internal diameter of the seal and a film of apiezon grease on the fuel side of the mating ring, outboard of the carbon seal track. As a result of this, the application of apiezon grease was revised; using care with how much is applied. Also, the fuel pump was to be baked after any grease application to allow excess to drain off. The obvious lesson here is to avoid excessive use of grease to component interface seals.

A large number of anomalies in the APU subsystem over the years have occurred within the thermal control system. All of these are well documented in the Shuttle PRACA database. These failures are typically categorized as one of three types: failed-on (e.g., failed-closed thermostat, heater short), failed-off (e.g., failed-open thermostat, wire open circuit), other (problems other than failed-on or failed-off cases). Of these, the most critical, and the one that presents the highest risk to the crew is the failed-on case. During qualification testing it was found that the heater "on" failure case allowed very little time for crew corrective action before unacceptable temperatures of $300^{\circ} \mathrm{F}$ in the fuel system were reached.

In the flight history of the Orbiter APUs, there are only 5 heater failed-on cases. One example was during the onorbit phase on STS-41, after the crew reconfigured the heaters from A to B, the fuel bypass line temperature increased from $110^{\circ} \mathrm{F}$ to $258^{\circ} \mathrm{F}$ after surpassing the fault detection and annunciation (FDA) limit of $180^{\circ} \mathrm{F}$ in approximately four minutes. The heater was then immediately returned to the 'A' system and operated nominally for the remainder of the flight. The unusually high temperature rise rate seen was due to a short to ground in that portion of the heater segment which was pinched during the replacement of the thermostat following a heater anomaly on STS-31. This heater string was not functionally checked after the thermostat replacement (this was missed during ground test because the failure was not in the heater string with the defective thermostat - it was the one next to it that was not subjected to ground test). This highlights the importance of performing a full functional check after any critical hardware is replaced. Most of the other thermal anomalies on the APU have been attributed to snap-action thermostat failures which, due to their location on high vibration zones, result in progressive wear of the internal bimetallic disc. These are typically replaced after each degraded performance in flight (e.g., narrowing control band of less than $6^{\circ}$ ). A lesson from this is that, in the long-term, design solutions are preferred over continuous maintenance.

The APU original design specification was for 10 years or 100 missions, whichever occurred first. Recognizing those requirements, when the 10 year limit was approaching, the APU community began developing a comprehensive maintenance plan for the APU hardware. This maintenance plan provided an economical long term periodic maintenance procedure for the APU to assure acceptable operation over the years. It accomplished many objectives including: ensuring the inherent safety and reliability levels of the APU hardware, restoring safety and reliability of the hardware when deterioration had occurred, obtaining and maintaining historical data for future use, obtain reliability data for design improvements, minimizing costs and unscheduled removals. The maintenance plan was developed using the following methodology: evaluation of data from flight and ground checkouts in relation to APU health, APU part failure history (in-flight, ground checkouts, vendor), and evaluation of part redundancy and criticality. In retrospect, for reusable systems, it is imperative to develop a maintenance program for the most critical components within all the subsystem. The maintenance plan, including periodic inspections, was found to be a true preventative effort and was significant factor in continuing the operation of the APU reliably over the years. In the case of the APU subsystem, it was deemed that the APU unit was the most critical and no other components needed periodic maintenance.

Another important lesson within the APU subsystem is the benefit of implementing fleet leader testing for critical hardware. By definition, the tested fleet leader hardware is of flight pedigree and is kept ahead of the fleet hardware in terms of total operational/cycle time. Establishing a fleet leader test program provides advanced indication of potential hardware degradation /problems, i.e., root out problems early. For the APU, fleet leader ground testing was performed on the APU unit as well as the APU fuel tanks. Selective non-destructive and destructive evaluations were performed over the years which allowed detailed assessments of component operational age life effects. 
The APU lessons described above and several additional ones are summarized in Table 1.

Table 1: Selected lessons learned in the APU subsystem.

\begin{tabular}{|c|c|}
\hline Problem Description & Lesson Learned \\
\hline $\begin{array}{l}\text { Hot re-start explosion during } \\
\text { qualification testing. }\end{array}$ & $\begin{array}{l}\text { - Design solutions to correct the problem cause are preferred over solutions } \\
\text { that treat the symptom. } \\
\text { - Assure safe emergency capability with design changes and operational } \\
\text { constraints. } \\
\text { - Avoid starts when hydrazine fuel feed system temperature is above } 200^{\circ} \mathrm{F} \text {. } \\
\text { - On hydrazine valves, ensure that hydrazine is well isolated from solenoid } \\
\text { cavity, use segmented solenoid coils to reduce the chance of overheating } \\
\text { due to shorts, and allow continuous safe operation. } \\
\text { - Importance of high-altitude thermal vacuum testing. }\end{array}$ \\
\hline $\begin{array}{l}\text { Detonation failure of fuel } \\
\text { isolation valve due to internal } \\
\text { bellows fatigue from surge } \\
\text { pressures. }\end{array}$ & $\begin{array}{l}\text { - A bellows design is not compatible with a fluid system that experiences } \\
\text { frequent, high ( } \sim 720 \text { psia) surge pressures. }\end{array}$ \\
\hline $\begin{array}{l}\text { Gas bubbles in hydrazine system } \\
\text { and potential for ABCD, e.g., } \\
\text { indications of gas bubbles on } \\
\text { STS-1 and STS-2. }\end{array}$ & $\begin{array}{l}\text { - Assure safe operational capability with operational constraints. } \\
\text { - Design hydrazine fuel systems to mitigate the possibility of large surge } \\
\text { pressures. } \\
\text { - Limit the maximum soakback temperature and dwell time above } 200^{\circ} \mathrm{F} \text { in } \\
\text { the hydrazine fuel system to minimize bubble formation. } \\
\text { - Avoid metal-to-metal contact as ignition source in hydrazine. } \\
\text { - Select a low bubble point pressure fuel filter to obviate trapping gas } \\
\text { bubbles. } \\
\text { - Reduce time between hydrazine fuel servicing operations and launch } \\
\text { (<month). } \\
\text { - Install burst disks on fuel drain system to reduce the potential of fuel line } \\
\text { pressure decay. }\end{array}$ \\
\hline $\begin{array}{l}\text { Gas generator roughness due to } \\
\text { voids in the catalyst bed }\end{array}$ & $\begin{array}{l}\text { - Utilize compression spring on gas generator to take-up voids as catalyst loss } \\
\text { occurs. }\end{array}$ \\
\hline Turbine wheel cracks. & $\begin{array}{l}\text { - Need to fully understand the operational environment. } \\
\text { - Incorporate a full-width shroud to support blade profile. } \\
\text { - Perform periodic NDE (e.g., penetrant inspections). } \\
\text { - Reduce the number of grinding operations. } \\
\text { - Use a controlled heating method. } \\
\text { - Specify weld inspection criteria after the finish is completed. }\end{array}$ \\
\hline $\begin{array}{l}\text { Contamination/wax formation in } \\
\text { gearbox from hydrazine and oil } \\
\text { mixing causing STS-2 launch } \\
\text { scrub. }\end{array}$ & $\begin{array}{l}\text { - A re-design to solve a design flaw is more cost effective than continuous } \\
\text { maintenance as a solution to an on-going problem. } \\
\text { - Compatibility of fluids must be well understood even if they are sealed from } \\
\text { each other; utilize dual seals if necessary. } \\
\text { - Change out lube oil between flights to avoid contaminant accumulation. } \\
\text { - Conduct qualification or fleet lead program to uncover time-related } \\
\text { problems. }\end{array}$ \\
\hline $\begin{array}{l}\text { STS-9 APU } 1 \text { and } 2 \text { fires during } \\
\text { entry and APU detonations post } \\
\text { landing caused by stress } \\
\text { corrosion cracking in GG } \\
\text { injector stems. }\end{array}$ & $\begin{array}{l}\text { - Reduce installation and removal stresses on critical materials; monitor if } \\
\text { necessary. } \\
\text { - Reduce residual carbon and stresses from manufacturing process. } \\
\text { - Minimize leakage between firings by improved seals. } \\
\text { - For reusable systems, implement periodic inspections (e.g., borescope) and } \\
\text { maintenance plan based on critical parameters and expand as } \\
\text { data/experience is gathered. } \\
\text { - Locate instrumentation in the vicinity of high criticality leak sources to } \\
\text { better enable fault detection, isolation and recovery. }\end{array}$ \\
\hline
\end{tabular}




\begin{tabular}{|c|c|}
\hline Problem Description & Lesson Learned \\
\hline & $\begin{array}{l}\text { - Minimize contamination and rust in any form which can act as hydrazine } \\
\text { catalyst. } \\
\text { - Limit the number of starts on hydrazine injectors. } \\
\text { - Change to chromized-layer injector also brought up the unintended } \\
\text { consequence of nitriding/flaking of chromium layer. } \\
\text { - Conduct qualification or fleet lead program to uncover time-related } \\
\text { problems. }\end{array}$ \\
\hline $\begin{array}{l}\text { Exhaust duct leakage during } \\
\text { qualification test. }\end{array}$ & $\begin{array}{l}\text { - Establishing a life limit on relatively inexpensive hardware that did not meet } \\
\text { qualification goals is sometimes more cost effective than re-design. }\end{array}$ \\
\hline $\begin{array}{l}\text { Exhaust Gas Temp (EGT) } \\
\text { failures }\end{array}$ & $\begin{array}{l}\text { - Deletion of frequently failing hardware that is no longer needed may be } \\
\text { more costly than re-design to prevent failure. }\end{array}$ \\
\hline Exhaust duct "E" seal leakage & $\begin{array}{l}\text { - Final leak checks should be done under the most realistic operating } \\
\text { conditions. }\end{array}$ \\
\hline $\begin{array}{l}\text { Diaphragm fuel tank ground } \\
\text { operation }\end{array}$ & $\begin{array}{l}\text { - Avoid the following: high rate of pressurization/depressurization causing } \\
\text { thermal excursions, reverse pressurization (fuel pressure > gas ullage) } \\
\text { causing diaphragm stretch, high pressure differential ( } 100 \text { psid) in the } \\
\text { normal direction (ullage }>\text { fuel). }\end{array}$ \\
\hline $\begin{array}{l}\text { Water cleaning process change } \\
\text { resulting in GGVM valve seats } \\
\text { cracks. }\end{array}$ & $\begin{array}{l}\text { - Carefully review all critical process changes; changes could bring more bad } \\
\text { than good. }\end{array}$ \\
\hline $\begin{array}{l}\text { On STS-1 Gas Generator Bed } \\
\text { heaters A and B failed due to } \\
\text { argon gas leak at a weld in the } \\
\text { GG heater common cavity case. }\end{array}$ & $\begin{array}{l}\text { - Verify that redundant elements are truly independent. } \\
\text { - Improve inspection techniques. }\end{array}$ \\
\hline APU high in-flight vibration & $\begin{array}{l}\text { - Verification of validity of operational limitations (i.e., redlines) and their } \\
\text { revision is preferred over re-design, if proven acceptable. } \\
\text { - Thoroughly review installation of control hardware to mitigate vibration } \\
\text { effects; re-locate or add vibration dampening. }\end{array}$ \\
\hline $\begin{array}{l}\text { Fuel pump detonation during } \\
\text { development test due to metal- } \\
\text { to-metal contact }\end{array}$ & $\begin{array}{l}\text { - For rotating shafts used in fuel systems, avoid designs that could result in } \\
\text { metal-to-metal contact as ignition source for a fuel detonation. }\end{array}$ \\
\hline $\begin{array}{l}\text { Fuel Line Heater failures (Failed } \\
\text { ON: STS-51B, STS-31, STS-34, } \\
\text { STS-41, STS-121) }\end{array}$ & $\begin{array}{l}\text { - Replacement is an interim solution - design change should be implemented. } \\
\text { Design solution is preferred over continuous maintenance. } \\
\text { - Design propellant heating systems to mitigate the risk of heater failed ON } \\
\text { condition or shorts, e.g., self-regulating or self-limiting heaters, solid-state } \\
\text { thermostats, segmented coil valves, DC-DC converters for power and } \\
\text { isolation, overtemperature thermostats close to the beginning of the heaters, } \\
\text { installing temperature sensors to monitor fuel line temps. } \\
\text { - Bi-metallic disc thermostat are susceptible to wear damage in high vibration } \\
\text { zones. } \\
\text { - Perform full inspection and functional checkouts/retest verification } \\
\text { - Following any hardware replacement or intrusive work and prior to flight. } \\
\text { - For fail-on heater in hydrazine systems, little time is available for crew } \\
\text { - Closely review Criticality } 1 \text { failure modes to eliminate their failure potential } \\
\text { or reduce failure probability to an acceptable minimum. } \\
\text { - Use caution that thermostat installation does not lie in vicinity of } \\
\text { neighboring components that can influence it to prematurely turn the heaters } \\
\text { off or on. }\end{array}$ \\
\hline $\begin{array}{l}\text { STS-62 rain water intrusion in } \\
\text { the aft resulting frozen fuel line. }\end{array}$ & $\begin{array}{l}\text { - Avoid rain water intrusion into critical systems; inspect if water intrusion is } \\
\text { suspected. Close vent and access doors prior to vehicle rollout. } \\
\text { - Areas should be identified within the vehicle where water may be trapped. }\end{array}$ \\
\hline
\end{tabular}




\begin{tabular}{|c|c|}
\hline Problem Description & Lesson Learned \\
\hline & - Design insulation system to avoid trapping water. \\
\hline $\begin{array}{l}\text { Fuel pump inlet pressure drop on } \\
\text { STS-73. }\end{array}$ & $\begin{array}{l}\text { - Avoid excessive application of grease in component interfaces and, if } \\
\text { possible, perform component bakeout post application. }\end{array}$ \\
\hline $\begin{array}{l}\text { STS-79 speed sensor mis-wire } \\
\text { resulting in APU shutdown } \\
\text { during ascent. }\end{array}$ & $\begin{array}{l}\text { - Hardware upgrades can bring unexpected sensitivities or unique set of } \\
\text { problems. } \\
\text { - Ground test hardware had same incorrect configuration as flight units. } \\
\text { - Consistent callouts across all levels of hardware drawings. }\end{array}$ \\
\hline $\begin{array}{l}\text { Multiple loose APU gearbox } \\
\text { pressure transducer installations } \\
\text { (one found after } 11 \text { missions), } \\
\text { due to installation procedure } \\
\text { flaw. }\end{array}$ & $\begin{array}{l}\text { - Torque requirements are generic and impact all systems. Whenever a } \\
\text { problem is encountered, check impacts to other subsystems. } \\
\text { - Actual torque can be masked by interference during torque application. } \\
\text { Verify torque procedure is adequately implemented and verified at each } \\
\text { location. Build custom tooling if necessary. }\end{array}$ \\
\hline $\begin{array}{l}\text { Importance of Fleet Leader } \\
\text { testing }\end{array}$ & $\begin{array}{l}\text { - Fleet Leader testing program provides advanced indication of potential } \\
\text { hardware degradation problems, mitigates costly and unscheduled } \\
\text { redesigns, and reduces overall risk. }\end{array}$ \\
\hline $\begin{array}{l}\text { Hydrazine seal cavity drain leaks } \\
\text { and relief valve failures on } \\
\text { multiple occurrences (leak, high } \\
\text { and low crack pressure, fail to } \\
\text { crack or relieve). }\end{array}$ & $\begin{array}{l}\text { - On hypergolic systems, addition of burst disc upstream of relief valve helps } \\
\text { in reducing the fuel vapor migration and contamination to relief valve and } \\
\text { possibility of seal degradation and leaks. } \\
\text { - Helium can permeate through Teflon on flexhoses and drop the line } \\
\text { pressure. } \\
\text { - Periodically cycle relief valves to break the rust and reduce stiction. } \\
\text { - IPA flushing and cleaning of components to reduce contamination. Clean all } \\
\text { interface fittings to the same level as the valves. } \\
\text { - When a dynatube fitting leaks, the flex hose should be taken off and } \\
\text { reinstalled per drawing to assure proper seating before other action is taken. } \\
\text { - Avoid fuel drain ports near access doors and/or assure adequate seals } \\
\text { against propellant re-ingestion into interior compartments. }\end{array}$ \\
\hline $\begin{array}{l}\text { Hypergolic Quick Disconnects } \\
\text { (QDs) leaks }\end{array}$ & $\begin{array}{l}\text { - QDs should be selected/designed for ease of maintenance; reduce SCAPE } \\
\text { operations. } \\
\text { - Design solutions for frequently failing high-cost hardware are preferred } \\
\text { over its repair/replacement. } \\
\text { - Heaters might be needed on hydrazine tank ullage lines and QDs. } \\
\text { - Periodic replacement of GSE filters. }\end{array}$ \\
\hline
\end{tabular}

\section{Orbiter Hydraulic Subsystem:}

The Space Shuttle Orbiter hydraulic subsystem consists of three completely independent hydraulic power generation and distribution systems designated as systems 1, 2 and 3 . This subsystem provides power to actuate aerodynamic flight control surfaces (elevons, body flap, rudder/speedbrake), main engine gimbal and valve controls, external tank umbilical retractors, main and nose landing gear uplock and deployment, main landing gear brakes, and nose wheel steering (Fig. 5).

As with most Orbiter systems, the hydraulic subsystem was certified through both tests and analyses. Qualification test included multiple test

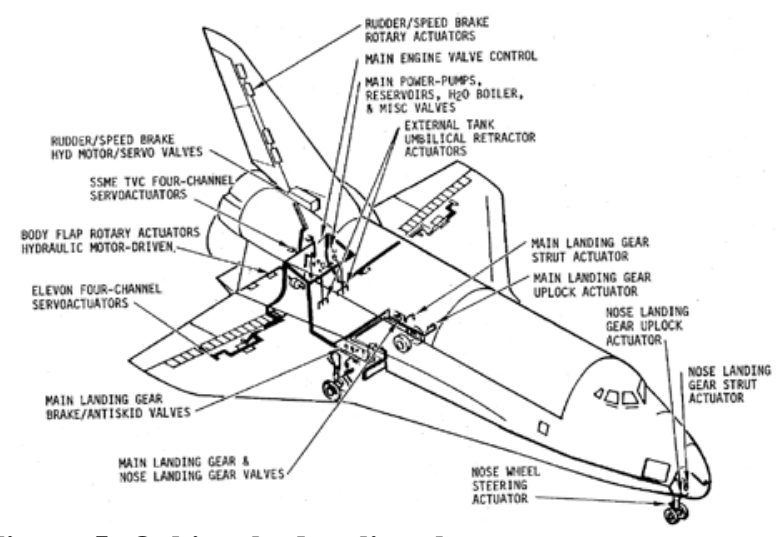

Figure 5: Orbiter hydraulic subsystem 
stands such as: Flight Control Hydraulic Laboratory (FCHL), Hydraulic System Thermal Test (HSTT) and Main Propulsion Test Article (MPTA). FCHL included the coupled hydraulic/flight control subsystems for closed loop simulation. It was used in a formal test mode to certify the overall hydraulic subsystem satisfied all its internal design and external interface requirements. In addition, it was used in a developmental mode to obtain engineering data to support the various analyses, to investigate special and extreme operating conditions (off limit testing) and to support flight failure analyses. Lesson learned is the importance of performing a comprehensive and integrated mission-representative qualification testing with production flight hardware to fully understand all interfaces and their combined interactions.

During STS-1, there were observed pressure spikes in hydraulic system 1 and 2 main pump outputs. Both the allowable pressure ripple of $+/-10 \%(+/-300 \mathrm{psi})$ and the allowable pressure spike were exceeded. Pump ripple can excite the natural frequencies of hydraulic systems producing spikes, causing high stresses and shortening the life of the hardware. However, analysis also showed that pressure ripple is significantly damped by the downstream filter. The lesson is to perform hydraulic dynamic testing and analysis with a flight representative system.

On STS-8, hydraulic circulation pump \#2 failed during hydraulic thermal conditioning. The crew attempted multiple starts with no success; later found to be caused by a piece of metal jamming and shearing the shaft. While attempting to start the pump, the crew left the power to the pump on for about 13 minutes. As a result, the motor/inverter electronics burned. The pump startup procedure was modified to turn power off after 60 seconds if the pump fails to start. Lesson here is to power off systems that fail to start after a specified time to avoid burnout and potential collateral damage.

During STS-76 ascent, a hydraulic system \#3 leak developed, with the leak rate increasing to $1 \%$ per minute. The hydraulic system \#3 main pump had been replaced during the STS-76 turnaround flow due to wire damage. There was also leakage from the high pressure line which was replaced as well. No high pressure leak checks had been done on the high pressure flexhose out of the pump. The system was redesigned later to move the check valve upstream to the pump outlet and allow high pressure leak checks with ground power. Lesson learned is to always verify the system integrity after any intrusive work is performed on the hardware and if possible, design the system for ease of integrity verification.

Hydraulic system contamination and silting has been the culprit of many anomalies throughout the Orbiter history. Hydraulic contamination is always an on-going challenge for the hydraulic community. Strict Orbiter Maintenance Requirement Specifications (OMRS) and fluid requirements are followed to minimize hydraulic system contamination. This is especially critical for close tolerance parts, e.g., servo-valves, low-flow and/or close tolerance control valves. As an example, during pre-launch confidence tests, main pump pressure fluctuations occurred prior to STS-81 and STS-97 due to contamination. These are typically resolved by circulating the hydraulic fluid through the GSE and Orbiter system filtering systems. Unloader valve leakages have occurred on several missions due to hydraulic contamination. Some have resulted in significant mission impact due to the need to continuously operate the circulation pumps on-orbit to maintain bootstrap accumulator pressure (e.g., STS-2, STS-7, STS-8, STS-41D, STS-41G, STS 51D, STS 51I). In addition, ET hydraulic umbilical actuators failed to retract due to suspected transient contamination on STS-119, STS-134 and prior to STS-130. It was concluded that contamination and silting accumulated on the ET actuators due to their low cycle use which allow particles to accumulate over time. Some lessons learned from these and other contamination-related hydraulic problems are: develop and implement a strict contamination control program, perform regular cycling of hydraulic components, particularly those with close tolerance internal parts, add a pre-filter to those critical components, regularly sample fluid and replace GSE filters.

Hydraulic bootstrap pressure decay has occurred multiple times due to life and system contamination issues with the piston accumulators. The purpose of the bootstrap accumulator is to pressurize the hydraulic reservoir to maintain sufficient inlet pressure to the main pump for startup. On STS-50, an accumulator leaked on orbit due to nibbling of Tseal caused by extrusion of backup ring, resulting from long term exposure to pressure (Fig. 6). It resulted in continuous circulation pump

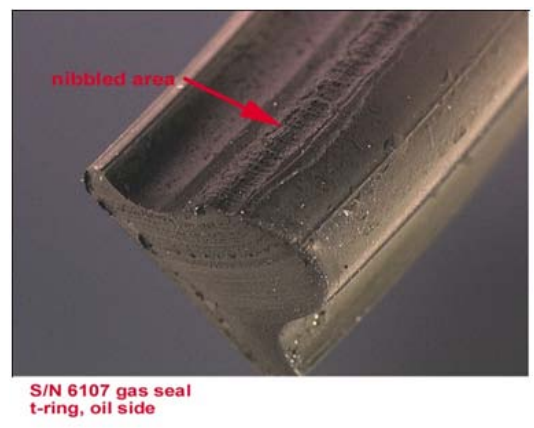

Figure 6: Hydraulic piston accumulator seal damage 
operation on-orbit. The majority of piston accumulators inspected have shown minor backup ring extrusion. As a result of this, a 4-year flight limit was imposed on all piston accumulators. A welded bellows accumulator-type design replaced the piston type design in 1999. No gas leakage has ever occurred from Orbiter (or SRB) bellows accumulator units. The bellows accumulator requires no servicing for the life of the accumulator. The obvious lesson here is the preferred use of welded bellows hydraulic accumulators to prevent leakage and loss of function.

Just prior to STS-109 launch, a routine inspection at the hydraulic main pump vendor found the pump's port cap bolts to be dry-film-lubricated (DFL) rather than passivated, as it is required. This resulted in overstress of the bolt inserts due to the lower friction, and reduced structural margin, resulting in damage to the housings. Several pumps inspected and x-rayed had sheared aluminum housing threads and significant insert movement (Fig. 7-8). This could result in hydraulic pump port cap separation and hydraulic fluid leak resulting in loss of a hydraulic system. STS109 launch rationale was given with the DFL bolts based on testing that indicated reduced, but sufficient margin remained to prevent leakage. A redesign of the port cap with passivated studs and self locking nuts resolved the concern. One lesson from this problem is to establish and verify adequate mandatory inspection points (MIP) in order to catch assembly errors. Another lesson is to carefully assess the use of helical coil inserts and the installation torque requirements, particularly in soft materials. This investigation highlighted the importance to design critical joints to be low maintenance with the capability to detect joint failure, easy to inspect, avoid moisture intrusion/corrosion, with high pullout strength and consistent preload (nut factor).

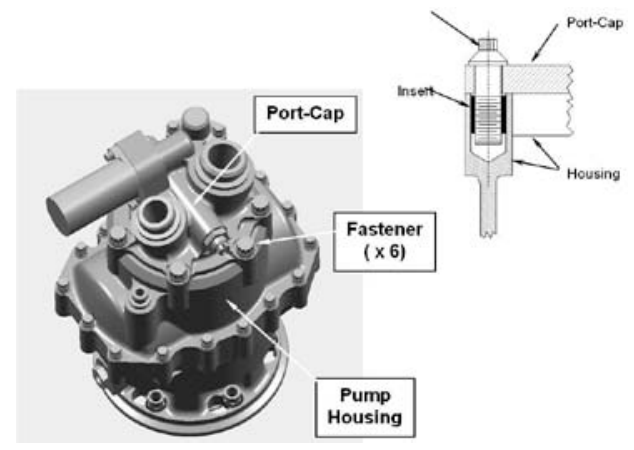

Figure 7: Hydraulic main pump port cap

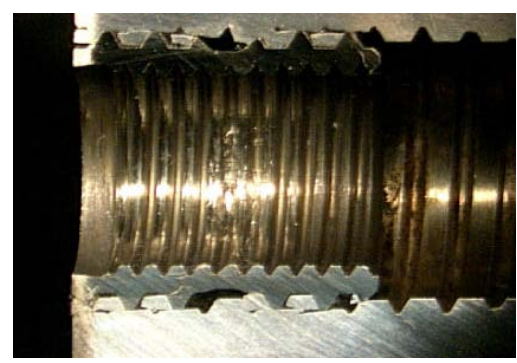

Figure 8: Hydraulic main pump port cap showing displaced helicoil insert and sheared aluminum housing threads

Contrary to commercial aircrafts, the Space Shuttle Orbiter did not initially establish a periodic maintenance interval for the flight control actuators. As most of the other Shuttle systems, the flight control actuators were certified to 10 yrs and 100 missions. Refurbishment of the elevon and TVC actuators occurred on a case-by-case basis, from the Program onset through the year 2001. These were driven by unscheduled removals for specific component repairs. Depending the typically limited disassembly, the actuators were repaired, rebuilt and underwent a partial acceptance tested prior to being delivered back as flight spares. Given the very few of these actuators that were disassembled during this period (i.e., $<5$ units) as well as the limited scope, very limited insight was obtained on the degradation of the internal component, including soft goods. In the case of the elevons and TVC actuators, the refurbishment effort was established as a result of a RSB Power Drive Unit (PDU) power valve failure during a Frequency Response Test (FRT) ground checkout, just prior to STS-101 in 2000. An extensive investigation into the

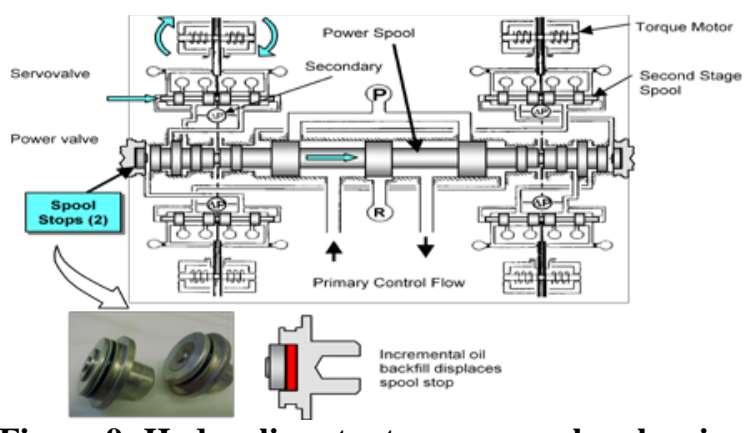

Figure 9: Hydraulic actuator power valve showing displacement of 2-piece spool stop restricting movement. root cause found that a spool stop on the power valve had moved due to accumulation of hydraulic oil behind the stops and subsequent incremental movement (backfill) with each operating cycled, restricting power valve spool movement (Fig. 9). This finding led to a subsequent re-design and refurbishment of similar actuators. In the interim, a unique ground tests (desilting test) was developed to closely track and trend the movement of the spool stops between missions and allow sufficient margins above the established limits. Subsequent review of earlier data indicates that the anomaly was present two years before (1998), but there were no requirements to review the secondary spool differential pressures, other than during FRTs. Lessons 
learned from this hydraulic actuator anomaly are: avoid spool stop inserts which can displace/unseat and restrict movement (e.g., design valve with single spool stop), always review critical parameter test data, establish a maintenance plan to assess hardware condition and refurbish damaged or degraded components. If a screening process is established it should be predictive rather than reactive.

Another example of a displaced/unseated insert on a hydraulic component occurred in early 2006. A failure occurred during the Acceptance Test Procedure (ATP) elevated temperature test where the internal retainer became loose and displaced; it should be fully seated in housing with positive interference or shrink fit (Fig. 10). This particular isolation valve had flown 9 missions on OV-103 prior to this finding. Dimensional inspection found the retainer seat and two other areas of housing bore to be oversized. Oversized housing condition resulted in negative interference with the retainer at elevated temperature. This defect appeared to be the result of manufacturing error in machining process. All similar valves installed on all Orbiters, were x-ray inspected ( 7 per vehicle), and no retainer displacement was detected in any other valve. However, due to concerns with subsequent failure of valves, a periodic in-situ vehicle x-ray inspection was instituted, which proved to be successful. Lessons from this event are: for interference fits assure positive interference is maintained at all temperatures, design hydraulic valves without retainers or with positive retention, successfully using $\mathrm{x}$-ray inspection for in-situ valve assessments in order to avoid costly removals and schedule impacts.

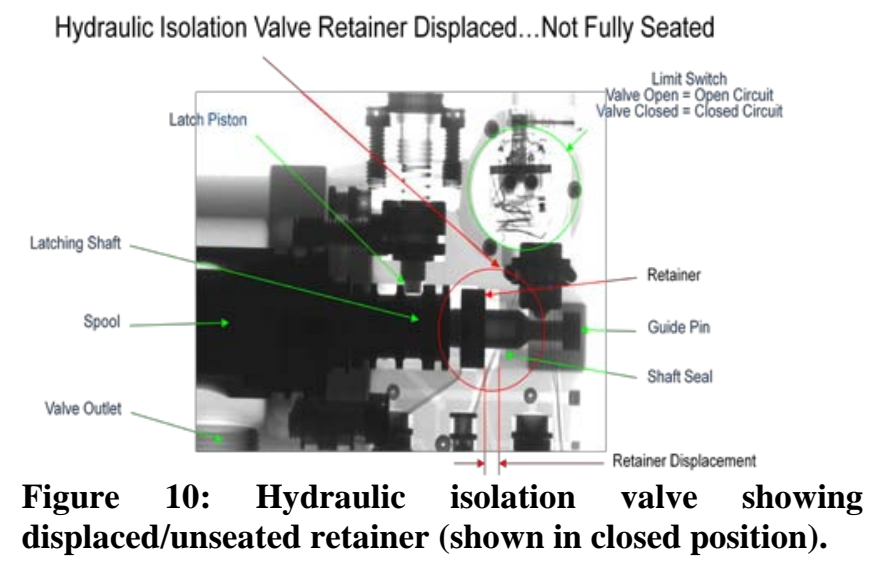

A hydraulic modification was proposed as an upgrade in the early 2000's to move the quick disconnects (QDs) to a panel located in the vehicle mold line at the 50-1 aft compartment access door. Each ground turnaround Orbiter flow requires approximately 20 hours of powered hydraulic operations. Installation and removal of the hydraulic QDs into the aft compartment accounts for and average of 3 Problem Reports (PRs) per flow. The modification was cancelled just prior to implementation due to impacts to the Return-to-Flight schedule. However, relocation of the hydraulic QDs to the mold line would have: eliminated the need to carry hydraulic GSE into the aft compartment, reduced foot traffic and potential collateral damage in the aft, and reduced installation/removal time.

There are advantages for future spacecraft to avoid the complexities and large infrastructure of the Orbiter hydraulic system, which requires continuous monitoring and maintenance to maintain system integrity and avoid leaks. Alternatives should be considered in the trade space of any future vehicle flight control system design such as utilizing localized hydraulics within the actuators, e.g., electro-hydrostatic actuators (EHAs), or eliminating hydraulics altogether, as in electro-mechanical actuators (EMAs). EMAs would reduce weight, increase reliability and safety, and decrease support and checkout requirements by eliminating both hydraulics and APUs.

The hydraulic lessons described above and several additional ones are summarized in Table 2.

Table 2: Selected lessons learned in the Orbiter hydraulic subsystem.

\begin{tabular}{|c|c|}
\hline Problem Description & Lesson Learned \\
\hline $\begin{array}{l}\text { Qualification tests with a flight } \\
\text { representative and integrated } \\
\text { hydraulic test system e.g., Flight } \\
\text { Control Hydraulic Laboratory }\end{array}$ & $\begin{array}{l}\text { - Essential to perform a comprehensive and integrated mission- } \\
\text { representative qualification testing with production flight hardware to } \\
\text { fully understand all interfaces and their combined interactions as well as } \\
\text { off-nominal testing. }\end{array}$ \\
\hline
\end{tabular}




\begin{tabular}{|c|c|}
\hline Problem Description & \begin{tabular}{|l} 
Lesson Learned \\
\end{tabular} \\
\hline \multicolumn{2}{|l|}{ (FCHL). } \\
\hline $\begin{array}{l}\text { During STS-1, observed pressure } \\
\text { spikes in hydraulic system } 1 \text { and } 2 \\
\text { main pump output. }\end{array}$ & $\begin{array}{l}\text { - Perform hydraulic dynamic testing and analysis with a flight } \\
\text { representative system. } \\
\text { - Verification of validity of operational limitations and their revision is } \\
\text { preferred over re-design, if proven acceptable. }\end{array}$ \\
\hline $\begin{array}{l}\text { STS-8 hydraulic circulation pump } \\
\text { \#2 failure. }\end{array}$ & $\begin{array}{l}\text { - Power off systems that fail to start after a specified time to avoid } \\
\text { burnout and potential collateral damage. } \\
\text { - Shuttle bus impedance ( } 60+\mathrm{ft} \text { wire runs) mitigated impact. } \\
\end{array}$ \\
\hline $\begin{array}{l}\text { During STS-76 ascent, a hydraulic } \\
\text { system \#3 leak developed, with the } \\
\text { leak rate increasing to } 1 \% / \text { min. }\end{array}$ & $\begin{array}{l}\text { - Always verify the system integrity after any intrusive work is performed } \\
\text { on the hardware. } \\
\text { - Even though a leak check is performed with ground power, subjecting } \\
\text { the component (e.g., flexhose) to vibrations could reveal a leak that } \\
\text { could go undetected. } \\
\text { - Design the system for ease of leak checking and integrity verification. }\end{array}$ \\
\hline $\begin{array}{l}\text { TVC actuator drift due to lock valve } \\
\text { leakage causing surge pressures } \\
\text { (waterhammer). }\end{array}$ & $\begin{array}{l}\text { - Match actuator command and position before hydraulic pump start } \\
\left(\leq 2^{\circ}\right) \text {. }\end{array}$ \\
\hline $\begin{array}{l}\text { TVC actuator commanded near } \\
\text { hardstop causing oscillations. }\end{array}$ & $\begin{array}{l}\text { - Avoid actuators with mechanical feedback or avoid commanding } \\
\text { actuators near mechanical stops. } \\
\text { - Careful selection and matching of servovalves; reduce tolerance stack } \\
\text { up. }\end{array}$ \\
\hline Piston accumulator leaks & $\begin{array}{l}\text { - Welded bellows accumulators have been better than piston accumulators } \\
\text { for preventing leakage. } \\
\text { - Piston accumulator tend to self-generate more contamination. }\end{array}$ \\
\hline $\begin{array}{l}\text { Unloader valve leaks resulting in } \\
\text { accumulator pressure decay. }\end{array}$ & $\begin{array}{l}\text { - Importance of contamination control. } \\
\text { - Add pre-filter to components with close-tolerance parts. }\end{array}$ \\
\hline $\begin{array}{l}\text { Hydraulic system contamination } \\
\text { and silting causing multiple } \\
\text { failures/leaks. }\end{array}$ & $\begin{array}{l}\text { - Important to implement strict contamination control requirements. } \\
\text { - Perform periodic de-silting procedures on critical hydraulic flight } \\
\text { - Institute Periodic/preventative maintenance of critical components. } \\
\text { - Ints (e.g., elevons, TVC). }\end{array}$ \\
\hline $\begin{array}{l}\text { Main Pump port cap to housing } \\
\text { pulled out inserts due to incorrect } \\
\text { use of bolts prior to STS- } 109 \text {. }\end{array}$ & $\begin{array}{l}\text { - Establish and verify adequate mandatory inspection points (MIP) to } \\
\text { catch assembly errors. } \\
\text { - Careful assessment of helical coil inserts, particularly in soft materials, } \\
\text { and torque requirements. } \\
\text { - Design critical joints to be: low maintenance with capability to detect } \\
\text { joint failure, easy to inspect, prevent moisture intrusion/corrosion, high } \\
\text { pullout strength, and preload consistency (nut factor). }\end{array}$ \\
\hline $\begin{array}{l}\text { Hydraulic isolation valve retainers } \\
\text { unseated/displaced, restricting } \\
\text { movement. }\end{array}$ & $\begin{array}{l}\text { - Be extra vigilant of internal valve retainers which can dislodge/displace } \\
\text { and restrict movement. } \\
\text { - For interference fits, assure positive interference is maintained and } \\
\text { properly seated at all temperatures. } \\
\text { - Use of periodic in-situ x-ray inspections to assess valve conditions and } \\
\text { avoid costly component R\&R. }\end{array}$ \\
\hline $\begin{array}{l}\text { Permaswage reducer tee fitting } \\
\text { cracks and leaks. }\end{array}$ & $\begin{array}{l}\text { - Avoid side loads on hard lines during installation. } \\
\text { - Utilize a more ductile material than titanium. } \\
\text { - Perform periodic inspections. } \\
\end{array}$ \\
\hline $\begin{array}{l}\text { RSB PDU spool stop displacement } \\
\text { prior to STS-101. }\end{array}$ & $\begin{array}{l}\text { - Avoid spool stop inserts, i.e., design valve with single spool stop. } \\
\text { - Establish a maintenance plan to assess hardware condition and refurbish } \\
\text { degraded components. } \\
\text { - Always review critical parameter test data. Subsequent review found } \\
\text { that the anomaly was present } 2 \text { years earlier but there were no }\end{array}$ \\
\hline
\end{tabular}




\begin{tabular}{|l|l|}
\hline Problem Description & Lesson Learned \\
\hline & requirements to review the data. \\
& $\begin{array}{l}\text { Freeze-plug technique successfully developed and implemented to } \\
\text { perform hydraulic hardware removals on the pad without need to drain } \\
\text { or isolate the interface lines. }\end{array}$ \\
\hline $\begin{array}{l}\text { Complexity, serviceability and } \\
\text { continuous leakage concerns with } \\
\text { hydraulic systems. }\end{array}$ & $\begin{array}{l}\text { Have all the hydraulic connections to the system at a mold line interface } \\
\text { panel (This will preclude collateral damage to system components when } \\
\text { having to install GSE for checkout and will reduce time of mates for } \\
\text { system checkout). } \\
\text { Design hydraulic quick disconnects such that pressure can be relieved } \\
\text { prior to mating. } \\
\text { - Institute periodic/preventative maintenance of components (includes } \\
\text { cleaning of subassemblies and replacement of seals). } \\
\text { - Consider electro-hydrostatic actuators (EHA) or Electro-mechanical } \\
\text { actuator technologies. }\end{array}$ \\
\hline
\end{tabular}

\section{Water Spray Boiler (WSB):}

The Water Spray Boiler (WSB) is a thermal control system that provides passive and active cooling capabilities to cool down hydraulic oil as well as the Auxiliary Power Unit (APU) lube oil. There are three independent WSBs in the Orbiter. Cooling occurs in the heat exchanger (container) which is comprised of a tube bundle flowing the two fluids to be cooled. Cooling is achieved through spraying water (or water/PGME mixture) onto the tubes, with the water vapor expelled overboard. The water tank is pressurized from a gaseous nitrogen (GN2) tank which is regulated down through a GN2 regulator/relief valve (Fig. 11).

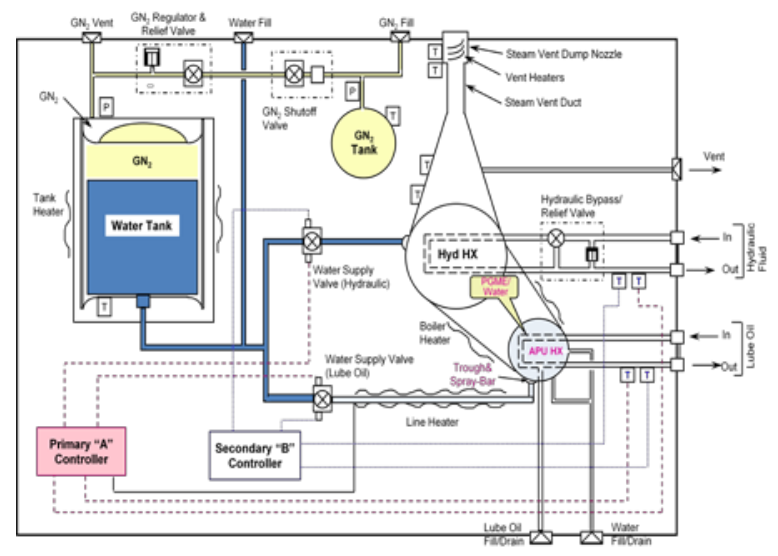

Figure 11: Water Spray Boiler system overview

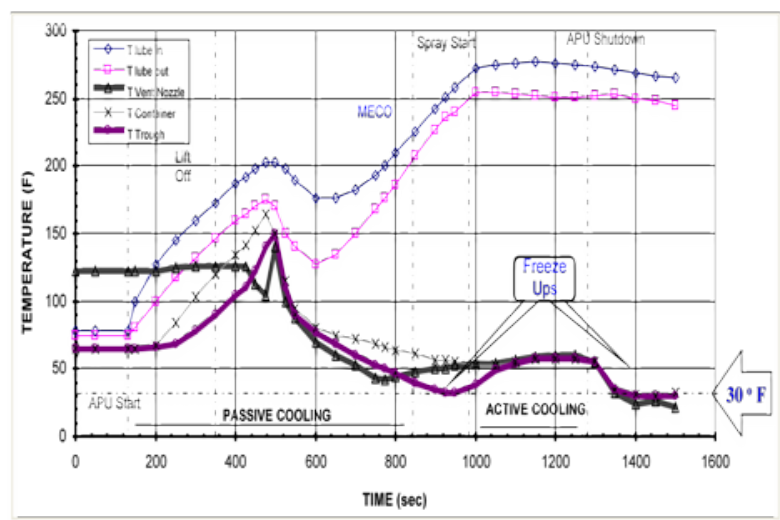

Figure 12: WSB temperatures during ascent

Throughout the shuttle history, the WSB has exhibited over 36 cases of freeze-ups flown with water pre-load ( $>33 \%$ of all the Orbiter WSBs) that prevented cooling, resulting in impacts to safety, mission success and mission operations. These freeze-ups typically occured during ascent, prior to APU shutdown, as well as post-APU shutdown, as a result of the ice formation that forms in the container under space vacuum conditions. The high altitude environment promotes water-to-ice formation via flash-freezing conditions above an altitude of 126,000 feet, where the ambient pressure drops below the water triple-point of 4 torr (Fig. 12). STS-3 had likely the most significant event where a WSB freeze-up resulted in the early (pre-MECO) ascent shutdown of an APU. Numerous unsuccessful design and operational attempts were taken to address the freeze-up problem. Implementation of an azeotropic mixture of Propylene Glycol Monomethyl Ether (PGME) and water successfully solved the problem. The lesson learned from this are: to avoid open to space vacuum cooling system where the cooling fluid pressure drops below its triple point, causing freeze-ups and blocking flow passages and orifices.

The WSB single-stage GN2 regulator/relief valve units have had numerous failures over the years. These failures manifest as: fail to crack, fail to reseat, internal leakage (creep) and external leakage. The majority of failures have 
been due to contamination, soft-goods degradation, and/or the quality of workmanship. Metallic and/or non-metallic contaminations, historically, caused the regulator internal and external leakage. Lessons learned from these include: selecting soft-good materials with higher strength and elasticity, imposing a tighter and cleaner ATP requirement at the vendor, and reducing the GN2 supply filter size, e.g., 10 microns.

The WSB low pressure sensors and vent nozzle heaters have experienced multiple failures. Use of stycast, a ceramic-based material used as sealant, tend to develop minute cracks over time which degrades its sealing capability. A change from stycast to a glass-based sealer (silicon oxide) resolved the problem.

Several GN2 isolation valves have failed decay checks over the years due to intergranular corrosion, predominantly limited to the weld. Investigation found the cause of the intergranular corrosion was the weld filler material (Cress-430) which develops larger structural grains. The corrosion started from the inside and propagated through the weld. Moist GN2 gets trapped within the void volume and initiates the corrosion process. Utilizing a bud-weld that fully penetrated along the tube cross section eliminates the void volume and allows no moist GN2 to be trapped. An inspection plan was developed (e.g., GN2 decay and GN2 quality maintenance checks) to identify the defected GN2 valves and remove them prior to becoming in-flight failures (IFA). Lessons learned from this includes: utilize weld filler materials that are resistant to moisture, periodically sample the GN2 for minimum moisture allowances, and continuously trend hardware data to uncover early any degraded performance.

Since the beginning, the WSB aluminum heat exchanger containers have always had corrosion problems (Fig. 13). Nine WSB containers were removed during the Orbiter flight history due to severe corrosion and external leakage, primarily at the inlet/outlet stainless steel connections. The average useful life was 12.5 years, based on actual corrosion time of aluminum containers in the fleet. Post landing sampling/analysis of container water revealed presence of aluminum oxide (Al2O3) corrosion byproducts. Using an aluminum water tank in an open system makes the tank prone to aluminum-oxide corrosion and bi-metallic galvanic effects. A galvanic corrosion couple is formed from the dissimilar metals (aluminum and stainless steel) in the presence of conductive water. Adoption of higher water quality control in 1990 and PGME/Water in 2001 slowed the corrosion process but did not eliminate it completely. A preferred solution would be to change the container material to a non-galvanic material such as titanium.

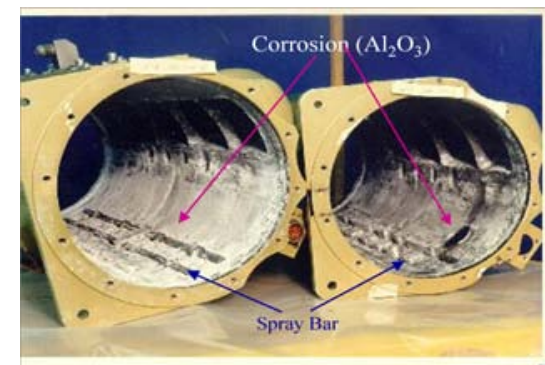

Figure 13: WSB heat exchanger containers showing evidence of galvanic corrosion

The WSB heat exchanger temperatures sensors have presented a unique set of problems over the years. The inlet and outlet temperature sensors were not placed in the most optimum location such that they are not truly representative of the inlet and outlet temperatures. Lessons from this are: to install independent (dual-bead) sensors at each heat exchanger inlet and outlets, make the controlling sensor the same or in the same location as the displayed/downlisted sensor), periodically check the temperature sensors calibration curve drifts.

The Water Spray Boiler lessons described above and some additional ones are summarized in Table 3.

Table 3: Selected lessons learned in the Water Spray Boiler.

\begin{tabular}{|c|c|}
\hline Problem Description & Lesson Learned \\
\hline $\begin{array}{l}\text { Water Spray Boiler freeze-ups on } \\
\text { more than } 30 \text { flights and }>33 \% \text { of } \\
\text { units. }\end{array}$ & $\begin{array}{l}\text { - Avoid open to space vacuum cooling system where the cooling fluid } \\
\text { pressure drops below its triple point; causing freeze-ups and blocking } \\
\text { critical flow passages and orifices. } \\
\text { - On open cooling systems, reduce the vent opening to maintain higher } \\
\text { gas/liquid surface pressure. } \\
\text { - Utilize a low vapor pressure cooling fluid. }\end{array}$ \\
\hline WSB regulator leaks. & $\begin{array}{l}\text { - Select soft-good materials with higher strength and elasticity. } \\
\text { - Impose a tighter and cleaner ATP requirement at the vendor. } \\
\text { - Reduce gas supply filter size (e.g., } 10 \text { microns). } \\
\text { - Avoid designs that require relief valve actuation as part of nominal } \\
\text { system operation, particularly during the dynamic ascent phase. }\end{array}$ \\
\hline
\end{tabular}




\begin{tabular}{|c|c|}
\hline Problem Description & Lesson Learned \\
\hline & $\begin{array}{l}\text { - Continuously trend hardware data to uncover early any degraded } \\
\text { performance. }\end{array}$ \\
\hline $\begin{array}{l}\text { Stycast cracks on component seals } \\
\text { (e.g., WSB low pressure sensor, } \\
\text { vent nozzle heaters). }\end{array}$ & $\begin{array}{l}\text { - Replace the stycast with a less brittle glass base sealer, e.g., silicon- } \\
\text { oxide, to avoid paths/cracks for leaks and corrosion. }\end{array}$ \\
\hline $\begin{array}{l}\text { Water valve leaks (e.g., E-brite } \\
\text { corrosion). }\end{array}$ & $\begin{array}{l}\text { - Physical inspect all critical welds. } \\
\text { - Perform double wrench torque test to verify bi-metallic joint integrity. }\end{array}$ \\
\hline $\begin{array}{l}\text { GN2 isolation valve failed pressure } \\
\text { decay due to intergranular } \\
\text { corrosion. }\end{array}$ & $\begin{array}{l}\text { - Utilize moisture-resistant filler materials on all welds. } \\
\text { - Reduce/control moisture levels in GN2 supply tanks. Periodically } \\
\text { monitor/sample moisture levels in GN2 systems. } \\
\text { - Continuously trend hardware data to uncover early any degraded } \\
\text { performance. }\end{array}$ \\
\hline $\begin{array}{l}\text { Water heat exchanger container } \\
\text { corrosion and external leakage. }\end{array}$ & $\begin{array}{l}\text { - Design water heat exchangers with galvanically compatible materials to } \\
\text { mitigate corrosion. } \\
\text { - Be careful in addressing corrosion problems by use of coatings. } \\
\text { - Higher water quality controls. }\end{array}$ \\
\hline $\begin{array}{l}\text { WSB heat exchanger temperature } \\
\text { sensor limitations. }\end{array}$ & $\begin{array}{l}\text { - Install independent dual-bead temperature sensors at each inlet/outlet of } \\
\text { heat exchangers. } \\
\text { - Use same location for the controller temperature sensors and downlisted } \\
\text { sensors. } \\
\text { - Perform periodic calibration curve drift checks and, if necessary, re- } \\
\text { pack with a high quality copper content and grease. }\end{array}$ \\
\hline Controller Overcool & $\begin{array}{l}\text { - Utilize digital controllers; this can also provide commonality with other } \\
\text { subsystems. } \\
\text { - Use a narrow band controller logic. }\end{array}$ \\
\hline
\end{tabular}

\section{Mechanical Flight Controls (MFC):}

The Orbiter Mechanical Flight Controls (MFC) consists of the rotary flight control actuators, i.e., four Rudder/Speedbrake (RSB) actuators and four Body Flap (BF) actuators, their source of mechanical shaft power from the RSB Power Drive Unit (PDU) and BF PDU, respectively, and the interconnecting drive shafts (Fig. 14).

Post STS-28, two BF actuators were removed and sent to the vendor for teardown and evaluation; this was driven by ascent video showing unexpected oscillation of the Body Flap surface. Concern with actuator overload damage drove a series of non-destructive evaluation of the internal gears. Unexpected wear of the planetary gears resulted in restricting the operational life to 22 flights for these original $\mathrm{BF}$ actuators. It also led to a subsequent redesign, which included: increased gear width and elimination of the Manganese Phosphate coating from all friction surfaces. Following implementation of this redesign in the 1990's, the limited life restriction was removed.

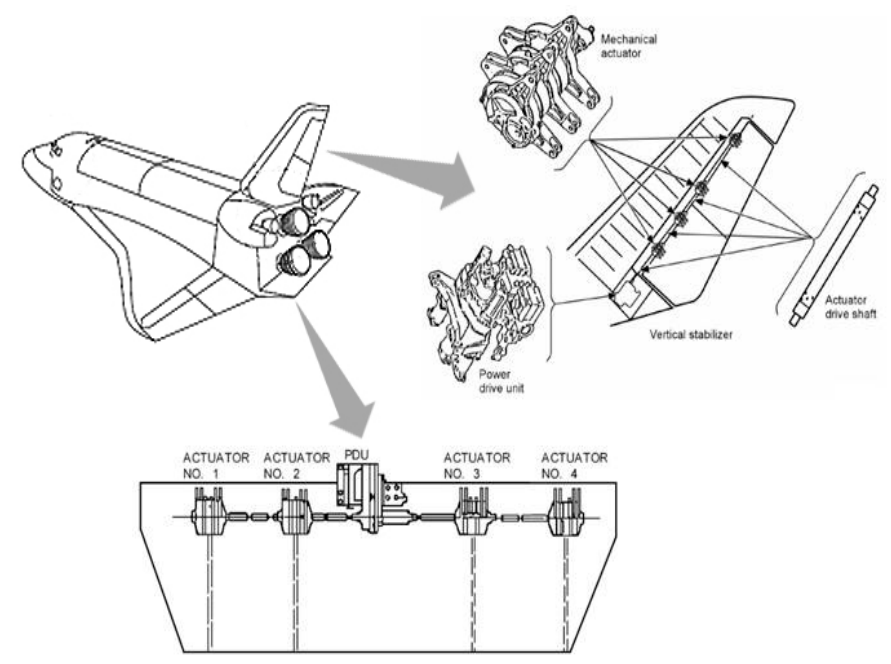

Figure 14: Mechanical Flight Controls

Beginning in 1991, inspection of the exterior surfaces of the BF and RSB actuators showed signs of corrosion pitting, primarily caused by the humid and salt environmental exposure at NASA KSC. Mitigations included efforts 
to arrest the corrosion via the implemented of a standard repair process consisting of rust removal, measurement and documentation of the damage (e.g., mold impressions) followed by the application of corrosion inhibiting grease throughout the housings. This external corrosion was more prevalent on the BF actuators due to their location within the body flap cove area and propensity to accumulate water. In addition, in the year 2000, a permanent rework to the $\mathrm{BF}$ actuators was incorporated by the vendor which consisted of stripping all corrosion and applying a new base phosphate coat and Super Koropon primer on all external surfaces. This design change, implemented on an attrition basis, proved to be significant in reducing the rate of corrosion on BF external housings.

As part of a fleet leader inspection effort, the fleet lead RSB actuator was removed from OV-103 in 2003. To everyone's surprise, considerable internal damage was found in the form of planetary gear and ring gear wear and fretting corrosion in addition to grease degradation (Fig. 15). The internal grease was yellow-colored and had decreased lubricity, with some physical oil separation and chemical breakdown. Some local gear teeth areas had reddish-brown grease, chemically-degraded from the fretting corrosion process. These findings had a considerable cost and schedule impact to the Program in that all fleet RSB actuators had to be inspected and most of them replaced, with all RSB actuators on OV-104 requiring the imposition of a limited life given that no available spares existed. These findings also led to Program-wide increased emphasis on corrosion and aging vehicle concerns. A lesson here is for future space applications to utilize greases with extreme pressure (EP) additives necessary for efficient boundary lubrication, better out-gassing qualities, corrosion-inhibitors and improved properties against physical separation and chemical breakdown.

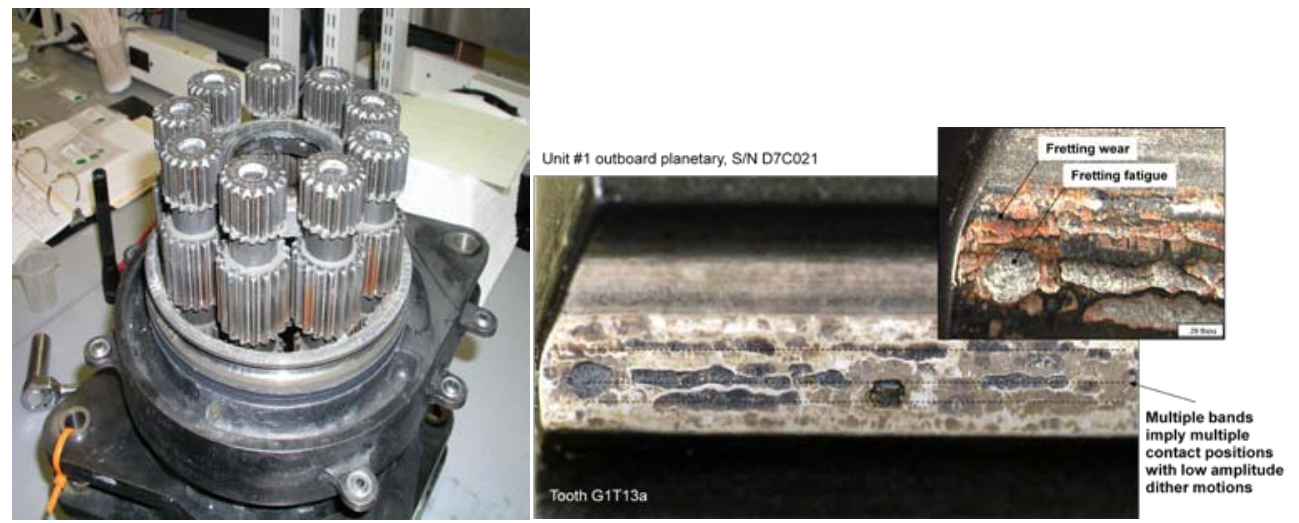

Figure 15: RSB actuator disassembly, showing the planetary gear set corrosion damage.

A review into the cause of the RSB actuator fretting corrosion found that the RSB PDU, which is the input source to the RSB actuators, imparted a small oscillatory motion (limit cycling or dithering) during the majority of the ground operations periods. As viewed from the RSB PDU and drive shafts, it appears as a "washing machine" type of motion. Over the hundreds of hours of ground operation, this RSB PDU limit cycling caused an unintended grinding or fretting of the internal RSB actuator gear teeth. As a mitigation, RSB drive shafts were removed during most of the ground processing operations to decouple the source of the damage. In addition, the Program began carefully tracking the duration of all RSB ground operations.

In addition, scheduled teardowns of RSB PDU at the vendor in 2003 and 2006 revealed many unexpected findings when the gearbox cavities were opened: significant gear scuffing, dark lubricating oil (MIL-PRF-83282), low oil level and significant particle contamination in the oil (Fig. 16). Silt and grease (Braycote 601) deposits were

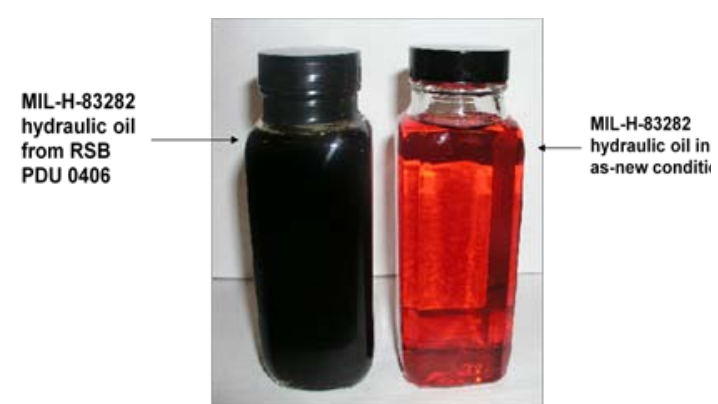

Figure 16: RSB gearbox oil comparison; new vs. old oil after 25 missions found in the brake cavities and throughout the units. These units had flown 25 missions. The internal gearbox on both the BF PDU and RSB PDU are sealed and isolated from the Orbiter hydraulic fluid circuit. In essence, this was equivalent to driving an automobile for more than 20 years without checking and replacing the transmission or engine oil condition. This finding led to an immediate fleet wide inspection of all RSB and BF PDU units, replacement of the gearbox oil, and periodic inspections thereafter. The team developed in-situ NDE inspection techniques to accomplish these objectives and, in some cases, avoid cost and schedule 
impacts. The obvious lessons from these findings are to perform periodic inspections on critical hardware, particularly on isolated fluid cavities that normally are not checked/sampled and are not continually filtered.

Inspection of four Body Flap PDUs in 2005 revealed that that their sealed gearboxes were overfilled with oil $\left(\sim 1600 \mathrm{~cm}^{3}\right)$, which could lead to a structural failure and loss of the system. The inspections were initiated as part of a fleet leader effort. Investigation found the cause to be internal leakage through the o-rings within the interfacing transfer tube (Fig. 17). There is no insight into this internal leakage post-assembly. It turns out that unless

GEARBOX

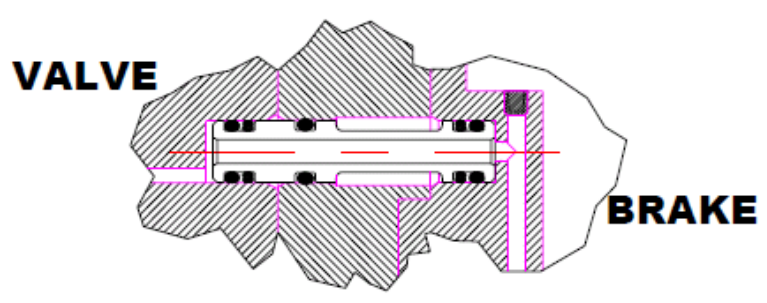

Figure 17: Body Flap PDU transfer tube

the brake is installed within 0.002 inches of its designed clocked location, the transfer tube o-rings and bores are not aligned concentrically, which may cause the o-ring in the brake housing to leak. Fed by high-pressure hydraulic fluid, this leak would drip directly into the sump of the gearbox raising its oil level. This leak may develop immediately or may develop over time as the o-ring ages in this non-concentrically loaded position. An assembly alignment fixture was build and all subsequent units did not show signs of internal leakage. The lesson here is to assure alignment of interfacing component seals, and conduct post-assembly leakage tests of gearboxes.

All of these inspections revealed a considerable amount of useful information, particularly as it relates to internal and external corrosion damage, as well as the condition of the internal soft goods and lubricants. The main lessons learned from these findings were: importance of establishing a fleet leader inspection plan to assess the condition of the hardware over time and uncover any unexpected issues, and the importance of performing periodic inspections of all critical hardware for external/internal corrosion damage. These fleet leader and periodic inspections were supplemented by specialized checkout tests, analytical model predictions, as well as continuous improvements to the standard OMRS process.

The Mechanical Flight Control lessons described above and several additional ones are summarized in Table 4.

Table 4: Selected lessons learned in Mechanical Flight Controls (MFC).

\begin{tabular}{|c|c|}
\hline Problem Description & Lesson Learned \\
\hline $\begin{array}{l}\text { External corrosion, internal wear, } \\
\text { and corrosion fretting of RSB and } \\
\text { BF actuators. }\end{array}$ & $\begin{array}{l}\text { - Perform periodic external and internal maintenance inspections on all } \\
\text { critical hardware for corrosion damage. } \\
\text { - Establish a fleet leader inspection plan to assess the condition of the } \\
\text { hardware over time and uncover any unexpected issues. } \\
\text { - Apply corrosion-preventive primer (e.g., Super Koropon) to all external } \\
\text { hardware surfaces. }\end{array}$ \\
\hline $\begin{array}{l}\text { RSB PDU gearbox discrepancies: } \\
\text { gear scuffing, } \\
\text { dark/contaminated/low oil level. }\end{array}$ & $\begin{array}{l}\text { - Perform periodic inspections on isolated fluid cavities that normally are } \\
\text { not checked/sampled and are not continually filtered, e.g., gearboxes. }\end{array}$ \\
\hline $\begin{array}{l}\text { RSB and BF actuators internal } \\
\text { grease degradation. }\end{array}$ & $\begin{array}{l}\text { - Utilize grease with extreme pressure (EP) additives necessary for } \\
\text { efficient boundary lubrication, better out-gassing qualities, more stable } \\
\text { base oil, corrosion-inhibitors and improved properties against physical } \\
\text { separation and chemical breakdown. }\end{array}$ \\
\hline BF PDU internal leakage & $\begin{array}{l}\text { - Assure correct alignment of interfacing seals and close-tolerance } \\
\text { components to prevent leakage, e.g., transfer tubes. Build special } \\
\text { alignment tooling if necessary. } \\
\text { - Conduct post-assembly leakage tests, particularly of internal } \\
\text { components with no available insight post- assembly. } \\
\text { - Conduct periodic inspection of critical hardware cavities such as } \\
\text { gearboxes. }\end{array}$ \\
\hline
\end{tabular}




\section{Main Propulsion System (MPS):}

The Space Shuttle Integrated Main Propulsion System (IMPS) consists of the ET, Orbiter MPS, and Space Shuttle Main Engines (SSMEs). Extensive GSE also exists to service, monitor, and maintain these elements. Overall, the IMPS is tasked with storage, conditioning, distribution, and combustion of cryogenic LH2 and LO2 propellants to provide first and second stage thrust for achieving orbital velocity. An overview of the Orbiter MPS portion of the IMPS is shown in Fig. 18. As indicated in this figure, nearly all of the MPS hardware is located in the Orbiter aft compartment. This includes the LH2 system, LO2 system, GH2 system, GO2 system, GHe system, GN2 system, and other miscellaneous items.

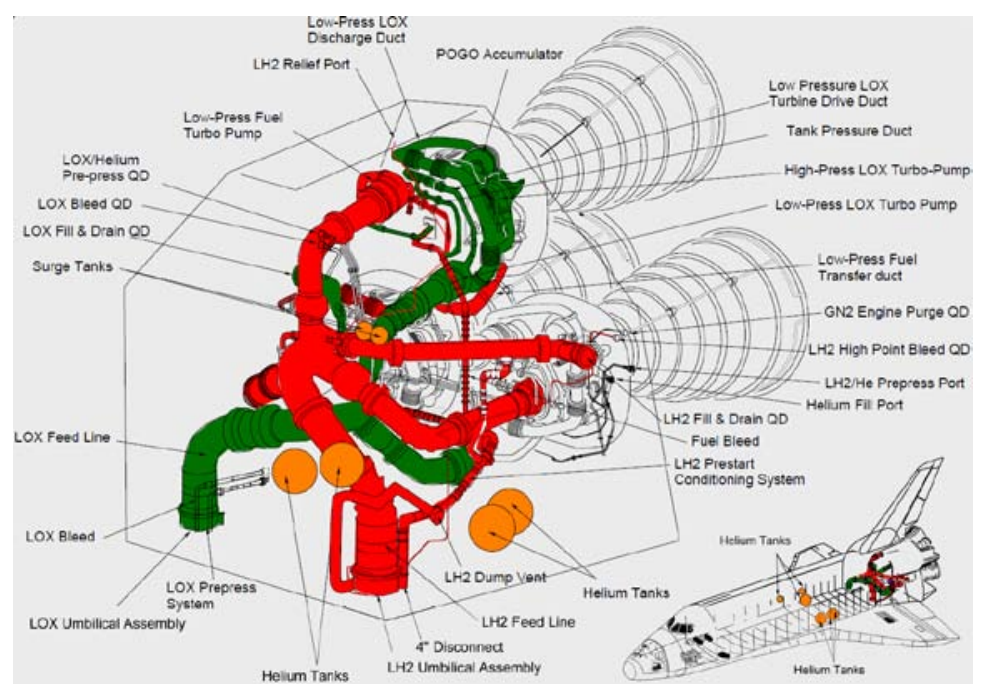

Figure 18: MPS Hardware Located in the Orbiter Aft Compartment

A cracked BSTRA ball was found in Orbiter vehicle OV-103 during routine propellant feed line inspections of its 17-inch LO2 manifold. Concerns associated with a cracked BSTRA ball included feed line structural failure, BSTRA joint malfunction, and SSME damage/failure from the ingestion of Foreign Object Debris (FOD) particles. Failure investigation work determined that the BSTRA ball cracks were caused by a defect related to an inadequate manufacturing process and poor quality screening. Silica inclusions from the sand cast process remained at the ball surface and created a thermal expansion mismatch with the Stoody 2 parent material, resulting in the formation of small thumbnail cracks during high temperature exposure associated with application of the Vitrolube coating. It was learned that the casting process can cause voids/inclusions in the parent material, leading to thermally-induced crack formation during subsequent steps in the manufacturing process or while in service. The Hot Isostatic Pressure (HIP) manufacturing technique can reduce or eliminate voids in the cast material as it cools. In addition, an inadequate acceptance testing and inspection process failed to detect the small cracks. This screening process should be made as robust as possible.

The MPS flowliners smooth the flow over the gimbal joint bellows and extend bellows fatigue life by eliminating flow induced vibration (FIV) in the feedlines. In 2002, cracks were discovered in the 12 inch feedline flowliner slots (Fig. 19). Since these liners are located in the gimballing joint immediately upstream of the SSME low pressure pump inlets, particle liberation into the SSME would be catastrophic. The cracks caused by previously uncharacterized vibro-acoustic coupling of the flowliner and slots with high order surging and rotating cavitation generated by the SSME low pressure fuel turbopumps. These cracks were repaired by welding them closed while still on the vehicle, and the flowliner slots were then precision-polished to remove any residual micro-cracks from the original slot punching process. In future applications, it is important to fully characterize the environment, especially across element interfaces where relatively little may be known. Avoid the use of stamped flowliner slots, favoring machining if required at all, especially where debris liberation is critical. 

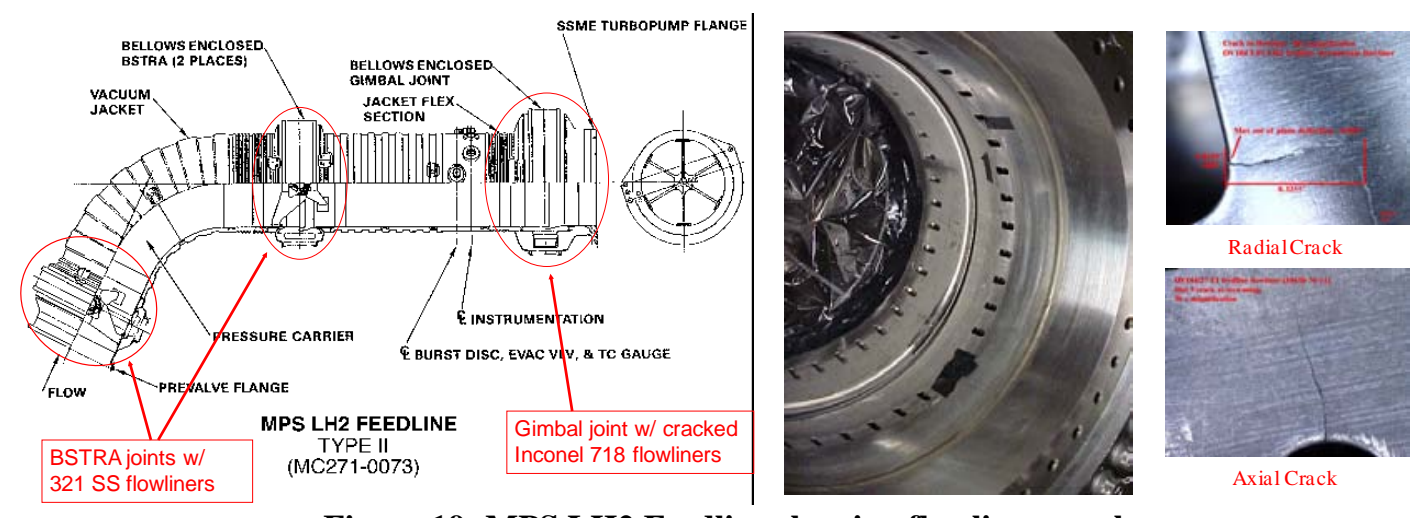

Figure 19: MPS LH2 Feedline showing flowliner cracks

During STS-126 powered flight, the engine\#2 Flow Control Valve (FCV) poppet broke across a portion of its flange (Fig. 20). This condition was detected via a change in inlet and outlet pressures though no command to change position had been sent. Since the poppet flange sees no impact loads, the cause was eventually deduced to be acoustic resonance caused by the high speed hydrogen gas exiting the valve. Special inspection methods were developed progressively as more was learned about the crack formation and propagation. Every flight valve tear downs and inspections were required to provide part of the continued flight rationale. It was learned that even structure with very high natural frequencies can be excited with acoustic inputs. Also learned was the fact that inspection methods need validation by complementary techniques, especially when cracks are very tight due to material properties and/or driving environment.

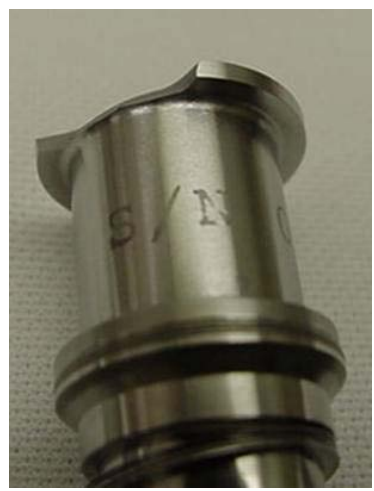

\section{Figure 20: STS-126 broken FCV poppet}

In the mid 1990's, a fill and drain valve failed in mid stroke during vehicle testing. The cause was found to be design dimensional characteristics of the clutch mechanism which allowed loads to be applied between inner and outer clutch drivers, leading to eventual interference and galling. What was learned was that a postulated case, that of a structural failure in the valve train mechanism giving a false positive position indication while the valve failed to stroke, can actually occur. In this case, the valve failed to stroke fully when it galled, but the switch correctly indicated its position. However, the key on the indicator shaft sheared during subsequent testing, demonstrating that the position indicators can be driven fully to the desired state without a corresponding valve mechanism movement. This propensity exists because of a fundamental design deficiency in this type of valve where its position indicators are installed upstream of the propellant valve element.

Composite Overwrapped Pressure Vessels (COPV) are currently used at NASA to contain high-pressure fluids in propulsion, science experiments and life support applications. In a COPV, the titanium or Inconel liner material is wrapped with Kevlar epoxy or Carbon/graphite overwrap. Prior to STS-114, flight certification of the Orbiter COPV's for stress rupture life was reviewed by the NASA Engineering and Safety Center (NESC) and identified as a flight risk issue. COPV fiber overwrap exhibits a failure mode known as stress rupture in which failure may occur at normal operating conditions and without warning, presenting a potentially catastrophic hazard. There has been extensive work in COPV's over the years and numerous references are available on this subject (Ref. 7). The Orbiter 
uses 24 Kevlar overwrapped pressure vessels for GHe and GN2 pressurant gas storage on MPS, OMS, RCS and ECLSS subsystems. As a result of the investigation, subsystem loading procedures were modified to limit temperatures and pressures during loading operations (e.g., staged pressurization), greatly increasing life. An important lesson was also to re-evaluate the original design assumptions with flight unit performance test data as it becomes available.

"Mid-life" certification reviews were performed on the Orbiter in 2003-2004 to extend its design life to the year 2020. During these reviews, many inadequacies in hardware certification were uncovered. Some of these were because of oversight at the time of certification; others were because the environments in which the hardware operates had changed with evolution of the Program. It is a good idea to periodically perform a review of environments for impact on hardware certification, using field and flight failure records as a guide on where to focus.

Shortly after Return-to-Flight (RTF) following the Columbia accident, an Engine Cutoff (ECO) electrical problem threatened to ground the fleet because of fears of a common cause that could render the entire cutoff system inoperative. The "low hanging fruit" were investigated first, leaving the actual root cause of the problem to be investigated after much effort had been expended. The culprit was indeed found to be the feed through connector located on the ET, through which all four circuits pass. The defective connector was intermittently failing at cryogenic temperatures, a problem cured by soldering the pins to the sockets ${ }^{3}$.

This portion of the paper considers only lessons learned during the design and certification phases of the Orbiter MPS hardware. Selected lessons learned in the MPS subsystem in the areas of component design and certification are summarized in Table 5.

Table 5: Selected lessons learned in the Integrated Main Propulsion System.

\begin{tabular}{|c|c|}
\hline Problem Description & Lesson Learned \\
\hline LO2 feedline BSTRA ball cracks. & $\begin{array}{l}\text { - The casting process can cause voids/inclusions in the parent material, leading to } \\
\text { thermally-induced crack formation during subsequent steps in the manufacturing } \\
\text { process or while in service. The HIP manufacturing technique can reduce or } \\
\text { eliminate voids in the cast material as it cools. } \\
\text { - An inadequate acceptance testing and inspection process failed to detect the } \\
\text { small cracks. This screening process should be made as robust as possible. }\end{array}$ \\
\hline LH2 feedline flowliner cracks. & $\begin{array}{l}\text { - Fully characterize the environment, especially across element interfaces where } \\
\text { relatively little may be known. } \\
\text { - Unintended consequences of fluid/acoustic environment, untested during } \\
\text { certification. } \\
\text { - Avoid use of stamped flowliner slots, favoring machining if required at all, } \\
\text { especially where debris liberation is hazardous. } \\
\text { - Proved success of “inspect and fly” methodology. }\end{array}$ \\
\hline Flow control valve poppet break. & $\begin{array}{l}\text { - Even structure with very high natural frequencies can be excited with acoustic } \\
\text { inputs. } \\
\text { - Inspection methods need validation by complementary NDE, especially when } \\
\text { cracks are very tight due to material properties and/or driving environment. }\end{array}$ \\
\hline Position indicator mounting location. & $\begin{array}{l}\text { - Valve position indicators should be installed downstream of the propellant valve } \\
\text { element rather than upstream at the actuator or in the drive train. }\end{array}$ \\
\hline COPV limited life due to stress rupture. & $\begin{array}{l}\text { - Use staged pressurization to reduce peak temperature seen during helium } \\
\text { loading operations, greatly increasing life. } \\
\text { - Important to re-evaluate the original design assumptions with flight unit } \\
\text { performance test data as it becomes available. }\end{array}$ \\
\hline
\end{tabular}




\begin{tabular}{|c|c|}
\hline Problem Description & Lesson Learned \\
\hline Engine cutoff system investigation. & $\begin{array}{l}\text { - The approach of going after "low hanging fruit" does not always save money or } \\
\text { time. } \\
\text { - The most likely, most dangerous cause should be investigated first. } \\
\text { - Common cause failures are very real and can seriously degrade system } \\
\text { reliability. }\end{array}$ \\
\hline Oxygen material compatibility. & $\begin{array}{l}\text { - The use of Inconel and Monel was determined to be preferable to stainless steel } \\
\text { based on the reduced propensity to ignite upon particle impact. } \\
\text { - Testing should always be performed in a representative GO2 environment to } \\
\text { ensure that design sensitivities are identified early. } \\
\text { - Careful consideration should be given to the use aluminum or aluminum alloys } \\
\text { for piece-parts that experience relative motion in a GO2 or LO2 system. }\end{array}$ \\
\hline Fail-safe bellows. & $\begin{array}{l}\text { - If bellows must be used in a highly dynamic component or system, a fail-safe } \\
\text { mode should be designed-in to avoid an undesirable condition in the event of a } \\
\text { bellows failure. }\end{array}$ \\
\hline GHe check valve poppet jamming . & $\begin{array}{l}\text { - Careful attention should be paid to the Length-to-Diameter }(\mathrm{L} / \mathrm{D}) \text { ratio, radial } \\
\text { clearances, and material selection when designing a sliding interface between } \\
\text { valve piece-parts. } \\
\text { - Perform representative testing, including high flow demand. }\end{array}$ \\
\hline $\begin{array}{l}\text { Sharp edges and corners on component } \\
\text { piece-parts. }\end{array}$ & $\begin{array}{l}\text { - Problem seen on several types of components. } \\
\text { - Use generous radii at edges along sliding surfaces, at neck-downs, and on } \\
\text { internal corner to prevent binding/jamming and reduce stress concentrations. }\end{array}$ \\
\hline Prevalve detent roller cracking. & $\begin{array}{l}\text { - A thorough tolerance stack up analysis should be conducted on all components } \\
\text { containing moving parts to ensure that worst-case tolerances will not cause } \\
\text { hardware malfunction or premature wear/failure. }\end{array}$ \\
\hline $\begin{array}{l}\text { Prevalve main seal cracking due to } \\
\text { slamming. }\end{array}$ & - Design control preferred over operational control. \\
\hline $\begin{array}{l}\text { Porosity in valve castings as a cause of } \\
\text { external leakage. }\end{array}$ & $\begin{array}{l}\text { - When troubleshooting leakage, consider possibility that through-body leakage } \\
\text { could be the source. } \\
\text { - Design a seal gland to preclude erroneously satisfying leak check criteria. } \\
\text { - Use Hot Isostatic Pressure manufacturing to eliminate porosity in castings. }\end{array}$ \\
\hline $\begin{array}{l}\text { Minimize use of flexhoses and protect } \\
\text { them from collateral damage. }\end{array}$ & $\begin{array}{l}\text { - For any spacecraft application, particularly on reusable vehicles, the use of } \\
\text { flexhoses should be minimized. } \\
\text { - Where flexhoses are deemed necessary, they should located away from areas of } \\
\text { high personnel traffic and protected from potential collateral damage. }\end{array}$ \\
\hline Torque relaxation in cryogenic joints. & $\begin{array}{l}\text { - Design cryogenic joints with materials having similar coefficients of thermal } \\
\text { expansion. } \\
\text { - Consider geometry to minimize thermal gradients and relative thermal } \\
\text { expansion. } \\
\text { - Design the lines and flange joint insulation for maximum access to bolts. } \\
\text { - Use Teflon-coated metallic seals rather than thicker non-metallic seals. } \\
\text { - For non-metallic seals, perform a re-torque after } 24 \text { or } 36 \text { hours. }\end{array}$ \\
\hline $\begin{array}{l}\text { Data time lag, gas mixing uncertainties, } \\
\text { and inability to monitor all systems for } \\
\text { hazardous gas leakage. }\end{array}$ & $\begin{array}{l}\text { - Use real-time hazardous gas detection system. } \\
\text { - Ideally, use it on the ground as well as during powered flight in order to allow } \\
\text { for crew response. }\end{array}$ \\
\hline $\begin{array}{l}\text { Complications of inerting hydrogen } \\
\text { systems in space. }\end{array}$ & $\begin{array}{l}\text { - The relief system should be a backup system by design, not one relied upon to } \\
\text { prevent system or vehicle damage. } \\
\text { - H2 tends to freeze on the cold walls of the system when exposed to vacuum, } \\
\text { making expulsion of the commodity difficult near its triple point. Relatively } \\
\text { warm GHe helps in sublimating the frozen H2, as does a lockup time before } \\
\text { another period of opening the system to the vacuum of space. }\end{array}$ \\
\hline $\begin{array}{l}\text { Subsequent failures caused by non- } \\
\text { representative vibration testing. }\end{array}$ & $\begin{array}{l}\text { - Simulate flight installation secondary structure when performing random } \\
\text { vibration qualification testing. }\end{array}$ \\
\hline $\begin{array}{l}\text { Potential for inadequate initial } \\
\text { certification and of program } \\
\text { requirements “creep". }\end{array}$ & $\begin{array}{l}\text { - Periodically perform a review of environments for impact on hardware } \\
\text { certification. } \\
\text { - Use field and flight failure records as a guide. }\end{array}$ \\
\hline $\begin{array}{l}\text { Problems with hardware certified by } \\
\text { similarity to other hardware in a "daisy }\end{array}$ & $\begin{array}{l}\text { - Avoid certifying hardware by similarity to other hardware which was itself } \\
\text { certified by similarity unless a very good basis of testing is known. }\end{array}$ \\
\hline
\end{tabular}




\begin{tabular}{|l|l|}
\hline Problem Description & Lesson Learned \\
\hline chain”. & \\
\hline $\begin{array}{l}\text { Designed-in features or analytical } \\
\text { margin are frequently not certified by } \\
\text { test. }\end{array}$ & $\begin{array}{l}\text { Perform burst testing, verification of redundancy, or operation with off-nominal } \\
\text { inputs as required to verify design. }\end{array}$ \\
\hline
\end{tabular}

\section{Orbital Maneuvering System (OMS) and Reaction Control System (RCS):}

The Space Shuttle Orbital Maneuvering System (OMS) and Reaction Control System (RCS) are a pressure fed hypergolic propulsion system using monomethylhydrazine (MMH) as the fuel and nitrogen tetroxide (NTO or $\mathrm{N}_{2} \mathrm{O}_{4}$ ) as the oxidizer. The Orbital Maneuvering System (OMS) provides orbit altitude adjustments for the space shuttle vehicle during the orbit phase, orbit insertion after ascent phase (OMS-2 burn), and the deorbit retrograde burn for the entry phase of flight. The OMS is located in two independent pods in the aft end of the Orbiter on either side of the vertical tail. Each OMS pod contains one OMS engine, a fuel tank, an oxidizer tank, and a helium tank, along with propellant feed lines, pressurization regulation, isolation valves, and other supporting equipment (Fig. 21).

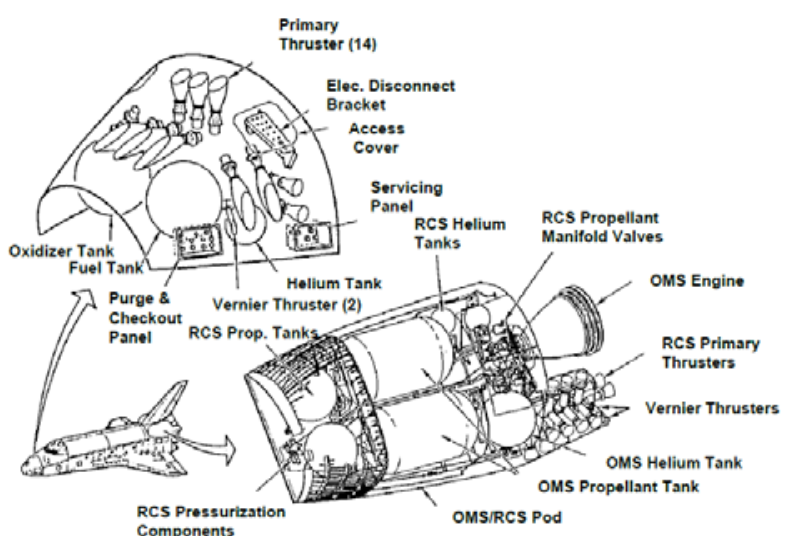

Figure 21: Forward RCS Module and OMS/RCS pods

The Reaction Control System (RCS) is located in the two OMS pods and the forward module of the vehicle. The RCS provides the shuttle with orbit attitude control using multiple thrusters and entry control until aero surfaces can provide sufficient control authority for the shuttle. Each of the pods and module contains a collection of jets (38 primary thrusters and 6 vernier thrusters in all), a fuel tank, an oxidizer tank, and two helium tanks, along with associated feedlines, pressurization regulation, isolation valves, and other supporting equipment. The Primary thrusters are rated at $870 \mathrm{lbf}$ vacuum thrust and the Vernier thrusters are rated at 24 lbf vacuum thrust.

Note at the end of this section, Table 6 documents the greater lessons learned in OMS/RCS. The Pilot Operated Valve (POV) for the primary thruster was the cause of many in-flight issues to which two topics (iron nitrate contamination and fuel valve extrusion) are highlighted below for the RCS system.

\section{Primary RCS Pilot Operated Valve (POV) fail-off or fail-leak due to iron nitrates}

The primary RCS thruster fail-off and fail-leak failure rate was increasingly high after 1988 return-to-flight and into the early 90's specifically with regard to the oxidizer valve. PRCS thruster redundancies were sufficient for the failures to date, however changing mission requirements and flight rules increased the criticality of the failure. This included contamination concerns associated with thruster valve propellant leakage during Space Station Mir missions and Low Z (aft firing and forward firing thrusters fired at same time provide a small translation in the Z axis) redundancy requirements for Mir rendezvous. High cost of repair and spares supportability were secondary issues. A Tiger Team gathered to address the issue. Gradual accumulation of metallic nitrates are believed to be the contributor to the majority of failures (Fig. 22). The failure mechanisms were grouped into two categories as such:

1. Immediate Failure Trigger

- $\quad$ Deserviced System - seal dry out resulting in leakage

- $\quad$ Cold Temperatures - seal shrinkage resulting in leakage

- $\quad$ Low System Pressure - decreased sealing load resulting in leakage

- Off-Nominal Conditions during thruster R\&R - eduction resulting in seal dry out and pulse purges (volume exchange operations) creating pressure surges and thruster leakage

2. Long Term Nitrate Accumulation 
- Moisture Intrusion - increased corrosion and nitrate formation

- $\quad$ Sustained Low level leakage - nitrate formation at leak site

- $\quad$ Oxidizer Quality - nitrate formation potential

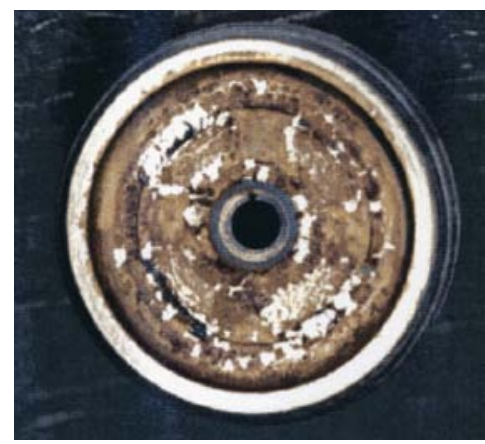

Figure 22: Iron nitrate on RCS POV pilot seat assembly

KSC vehicle processing changes mitigated nitrate formation potential. Nitrogen tetroxide (oxidizer) is hygroscopic and will accelerate corrosion and formation of nitrates with moisture intrusion. Thruster R\&R would require breaking into the system and attempting to keep moisture out. Rather than conducting a 'hot' R\&R and risking moisture intrusion, procedure now directs a manifold drain and decontamination to the toxic vapor limit such that if air is introduced during thruster removal, nitric acid and iron nitrate formation is minimized. An internal active purge was designed to serve as a moisture barrier while all thrusters on a given manifold are removed for $R \& R$. Seal saver installation in dynatubes is now required for all thruster R\&R's to minimize leakage. A new thruster purge system was developed to keep oxidizer vapors out of thruster chamber area as well as air moisture away from the valve seat since oxidizer vapors contribute to Fuel/Oxidizer Reaction Products (FORP) formation and later found to be the cause of fuel valve seat extrusion. Better thermal management for leakage and keeping lines hard filled during all phases of the vehicle flow processing were also implemented. Mole sieve was eventually implemented at KSC and WSTF to improve oxidizer quality.

The combination of all the above procedure changes and added designs to mitigate moisture intrusion contributed to a significant decrease in thruster failures. However, as discussed in the next lesson learned subject, some changes increased the likelihood of another failure mode. The main lesson learned here is that a properly maintained hypergolic system can mitigate or nearly eliminate nitrate related ground and in-flight failures.

\section{Primary RCS POV fuel valve seal extrusion due to oxidizer vapor:}

Primary Thruster fuel valve extrusion was first discovered in 1995-96 during failure analysis following thruster failure during STS-68 and was expanded when other failures started occurring during thruster Depot processing. Conclusions from 1995-96 effort were not conclusive on the exact mechanism causing extrusion but did show correlation with a ground operations change. The extrusion mechanism was thought to be caused by either a onetime event high grade fuel/oxidizer reaction or a combination of low grade reaction with thermal cycling in a localized area at or near the pilot seat. In particular, WSTF thermal and exposure tests in 1995 had success in duplicating extrusion but results could not distinguish between these two causes. During the STS-68 failure investigation, it was also determined that due to the compressibility of GN2, fuel valves with extruded seals would exhibit slow main stage opening response or failure to open when actuated with GN2 while still passing response testing performed with liquid water or propellant; thus, fuel valve GN2 response testing was implemented as a Depot screen for fuel valve extrusion.

Extrusion failures continued at a high rate after development of the GN2 response screen ( $\sim 60$ cases of fuel valve extrusion have been detected since initial failure, 8 per year average). Unfortunately, the screen was unable to prevent later in-flight failure and anomalies (10 flight failures through 2006). The occurrence of the last 6 in-flight failures during STS-108 and -110 triggered formation of the Thruster Process Evaluation Team (TPET) to determine causes and improved corrective actions for fuel valve extrusion. The fact that fuel valve extrusion was not a problem for the first 15 years of Orbiter operations suggested that the cause was due to a change in thruster processing or usage. 
In the early 1990's, the Universal Throat Plug Assemblies (UTPA) were developed to provide a better seal against moisture intrusion in the chamber to protect against nitrate formation at the oxidizer valve. Nitrates were determined to be formed when oxidizer is exposed to moisture (as mentioned in the previous lesson learned topic). At the valve seat, nitrate accumulation typically resulted in either a sticky or a leaky valve. The UTPA worked well, but when coupled with increased throat plug installation time at KSC, a high oxidizer-vapor environment was inadvertently created in the thrust chamber. In late 1998, another processing change was made when a chamber trickle purge was implemented in an attempt to maintain a dry environment in the chamber and to reduce the oxidizer vapor concentration. This trickle purge was not always effective in practice. It was undersized, inefficient, and unreliable. The trickle purge was not active such as at the Vehicle Assembly Building (VAB) or when the pod or module was removed and located in the transfer aisle. Purge-down time allowed oxidizer concentrations in the combustion chamber to build rapidly.

The TPET concluded that the fuel valve extrusion phenomenon was the result of a fueloxidizer reaction within the Teflon seal itself. Oxidizer vapor has been shown to readily permeate into PTFE (Teflon). Evidence of FORP within the PTFE pilot seals suggests that fuel may be forced into the semi-porous PTFE seal with regulated pressure and then reacts with the permeated oxidizer vapor. The reaction of the fuel and oxidizer would produce heat and evolve gas as a portion of the reaction by-products. It is therefore possible that evolved gas increases the internal void space of the

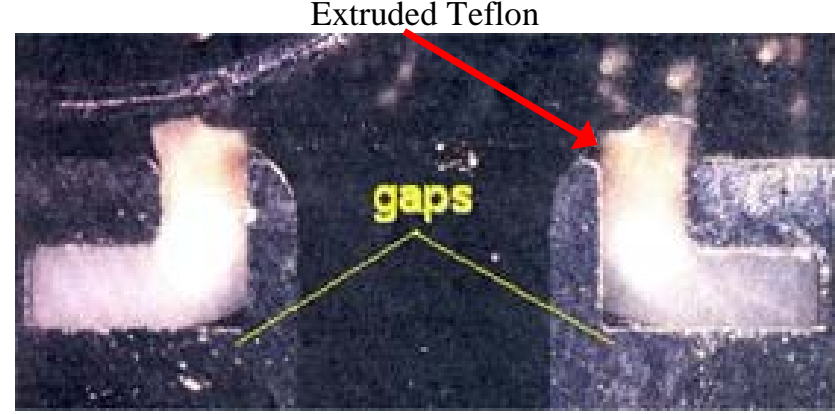

Figure 23: STS-68 POV extruded Teflon seal and voids

PTFE by mechanical force, thus, causing expansion and a decrease in the density of the polymer. The extruding seal is not "walking out" of its retainer cavity, but instead the volume of the seal is increasing due to the larger internal voids. As a result, the seal extruded upward into the pilot stage flow path since that is the only unconstrained direction, as seen in Figure 23.

The TPET investigation also resulted in the development of another extrusion screening technique utilizing the pilot stage electrical current trace recorded during the water response test. Review of the failed valves and new valves revealed that as the seal extruded upward, the shape of the current trace inflections change. In many cases, the valve may successfully pass the GN2 response test but exhibit an off-nominal current trace shape indicating some extrusion of the seal.

Slow opening of the primary thruster fuel valves was caused by extrusion of the pilot stage Teflon seal. As the seal extrudes, the flow area of the pilot stage is reduced, effectively slowing the opening response of the valve. Extrusion is a slow process that occurs after weeks to years of exposure to oxidizer vapor during ground turnaround operations. Several corrective actions have been put in place, including reducing the allowable leakage of oxidizer valves and the new current trace extrusion screening technique. In addition, an improved chamber purge GSE design was implemented in 2006 allowing oxidizer vapor concentration to be maintained at a lower level. The simplicity of new purge GSE design reduced the cumulative purge downtime by reducing the time required to bring the purge up and down, increasing the ability of detecting a GSE leak, and allowing an active purge while in the VAB.

The lesson learned here is that process is key when managing environments. The throat plug with purge assembly was designed primarily to help keep out moisture to address the nitrate formation and thruster failure issues, yet the plug also unintentionally trapped oxidizer vapor. An implemented trickle purge assembly meant to keep the chamber dry did not trickle at sufficient rates to rid the thruster chamber of vapor. This along with the inactive purge at certain points in the Orbiter processing flow allowed time for accumulated vapor to react at the fuel valve seat (this is another example of changes bringing unintended consequences). Tightening oxidizer leak requirements, trickle purge requirements and redesigning the purge assembly corrected the fuel valve extrusion while continuing to address the earlier nitrate formation issues. Developed current trace screen allowed for evaluation of seal extrusion without unnecessary valve disassembly at the depot. Since return-to-flight (STS-114 to end of program) in-flight thruster failures due to nitrate formation or fuel valve extrusion were non-existent. 
The OMS/RCS subsystem lessons described above and several additional ones are summarized in Table 6 .

Table 6: Selected lessons learned in the OMS/RCS subsystems.

\begin{tabular}{|c|c|}
\hline Problem Description & Lesson Learned \\
\hline $\begin{array}{l}\text { PRCS POV fail-off or fail leak due } \\
\text { to iron nitrates. }\end{array}$ & $\begin{array}{l}\text { - A properly maintained hypergolic system can mitigate or nearly } \\
\text { eliminate nitrate related ground and in-flight failures. } \\
\text { - Need integrated hardware qualification testing with propellant, moisture } \\
\text { and time exposure (Qualification was done incrementally and not } \\
\text { integrated along with time exposure). } \\
\text { - Implement preventative maintenance schedule to minimize in-flight } \\
\text { failures by flushing all thruster valves periodically. } \\
\text { - Full manifold R\&R to prevent sympathetic failures. } \\
\text { - Implement thruster chamber moisture control during ground operations } \\
\text { - since nitrogen tetroxide is hygroscopic and will generate nitrates. } \\
\text { - Reduce low-level oxidizer leakage at the poppet/seat interface. } \\
\text { improve the corrosion resistance of materials at the poppet/seat } \\
\text { - Minimize contact area between mating parts/surfaces to decrease } \\
\text { potential nitrate-related stiction. }\end{array}$ \\
\hline $\begin{array}{l}\text { PRCS POV fuel valve seal } \\
\text { extrusion. }\end{array}$ & $\begin{array}{l}\text { - Thruster chamber moisture control hardware needs to provide sufficient } \\
\text { ventilation of oxidizer vapor through use of a purge system. Purge } \\
\text { system should be active through all phases of vehicle flow and flight } \\
\text { preparation to prevent oxidizer vapor reactions with the fuel valve seat. } \\
\text { - Thruster valve leak rate tolerances should be small to mitigate potential } \\
\text { for thruster valve seat extrusion. } \\
\text { - Use GN2 flow rate test to screen for failure. Consider developing } \\
\text { current trace as part of screening method. }\end{array}$ \\
\hline PRCS combustion instability. & $\begin{array}{l}\text { - Although generally stable, instabilities were induced when helium } \\
\text { bubbles injected into the fuel stream (propellant saturated with ullage). } \\
\text { - Add stability screening test to thruster hot-fire ATP. } \\
\text { - Add wire wrap as protection for thruster instability. }\end{array}$ \\
\hline $\begin{array}{l}\text { FORP and Pc sense tube burn } \\
\text { through resulted in near catastrophic } \\
\text { failure on STS-51. }\end{array}$ & $\begin{array}{l}\text { - Improve Pc tube design, e.g., avoid “S” shaped tube configuration or } \\
\text { increase tube thickness. } \\
\text { - Develop Pc tube flushing schedule to remove FORP. } \\
\text { - Do not fire a suspect thruster during flight unless conditions are well } \\
\text { understood and covered by qualification testing. Rather, inhibit and } \\
\text { reprioritize thruster unless needed as a last resort. } \\
\text { - Avoid very short firings; smaller impulse bit equates to less efficient } \\
\text { combustion and more FORP formation. }\end{array}$ \\
\hline $\begin{array}{l}\text { PRCS thruster injector relief radius } \\
\text { and counterbore cracks due to } \\
\text { cleaning and bake-out process. }\end{array}$ & $\begin{array}{l}\text { - Cleaning process and procedure development should consider material } \\
\text { compatibility for all phases of the hardware production/preparation } \\
\text { process (in this case, residual etchant remained in hard-to-rinse areas } \\
\text { and the high temperature bake process caused material cracking). }\end{array}$ \\
\hline $\begin{array}{l}\text { Vernier thruster reboost results in } \\
\text { valve overtemperature. }\end{array}$ & $\begin{array}{l}\text { - Restrict vernier usage to specific reboost duty cycles. Develop go-no-go } \\
\text { duty cycle criteria for long duration reboost requirements. }\end{array}$ \\
\hline $\begin{array}{l}\text { Primary thruster injector } \\
\text { intergranular cracking. }\end{array}$ & $\begin{array}{l}\text { - Elimination of pre-weld etch (Use of diamond coated cutting tool or } \\
\text { titanium nitride coated cutting tool specified in machining operations). } \\
\text { - Thorough review of thruster cleaning process to minimize cracks }\end{array}$ \\
\hline $\begin{array}{l}\text { Flight failures occurring prior to } \\
\text { ground test failures. }\end{array}$ & $\begin{array}{l}\text { - Periodically update fleet leader test article profiles to reflect flight } \\
\text { usage. } \\
\text { - Consider simulating similar ground environments and maintain fleet- } \\
\text { like status with all hardware components and processes. This could have } \\
\text { caught multiple failure types if process changes were captured in }\end{array}$ \\
\hline
\end{tabular}




\begin{tabular}{|c|c|}
\hline Problem Description & Lesson Learned \\
\hline & fleetlead program. \\
\hline $\begin{array}{l}\text { Primary RCS thruster L1L injector } \\
\text { failure in ground test. }\end{array}$ & $\begin{array}{l}\text { - Avoid the unique set of ground test conditions that can lead to intra- } \\
\text { manifold explosions such as: leaking thruster valves, leak duration, } \\
\text { horizontal configuration, ambient pressure and thermal conditions. } \\
\text { - Avoid firing leaking thrusters in ground testing. }\end{array}$ \\
\hline $\begin{array}{l}\text { Sluggish regulator due to plugged } \\
\text { sense tube }\end{array}$ & $\begin{array}{l}\text { - As soon as practical (i.e., post-landing), isolate the regulators from the } \\
\text { propellant tank vapors or purge with inert gas to remove residual vapors. } \\
\text { - OMS spiral restrictor tube design does not have contamination issues } \\
\text { like the old RCS straight tube design. }\end{array}$ \\
\hline Quad check valve sticking issues & $\begin{array}{l}\text { - Unless the design calls for all joints to be hermetically sealed, assume } \\
\text { oxidizer vapors will leak. }\end{array}$ \\
\hline $\begin{array}{l}\text { Thrust chamber chips (R-512 } \\
\text { discilicide coating mechanically } \\
\text { induced spalling). }\end{array}$ & $\begin{array}{l}\text { - Perform periodic inspections and track growth of known chips. } \\
\text { - Injector film cooling provides longer primary thruster chamber life. } \\
\text { - Characterize chips and develop acceptance rationale such that thruster } \\
\text { nozzles do not need to be R\&R for every chip. Columbium nozzles with } \\
\text { disilicide coating is more robust than initially understood. }\end{array}$ \\
\hline $\begin{array}{l}\text { OMS quantity gauging fuel probes } \\
\text { problems. }\end{array}$ & $\begin{array}{l}\text { - Have alternate/redundant quantity gauging methods, e.g., ground } \\
\text { loading gauging, in-flight engine firing time integration, PVT } \\
\text { calculation. } \\
\text { - Manufacturer's expertise was with capacitor gauging sensors and not } \\
\text { with complex electronic systems (totalizer). Recognize manufacturer's } \\
\text { expertise and limitations. Need right expertise for right technology. } \\
\text { - More thorough acceptance test to screen out deficiencies in quality } \\
\text { process. }\end{array}$ \\
\hline $\begin{array}{l}\text { Propellant residue and } \\
\text { contamination resulting in } \\
\text { component leakage. }\end{array}$ & $\begin{array}{l}\text { - Install hardware to prevent propellant migration or utilize robust } \\
\text { pressurization components that can endure propellant vapor migration } \\
\text { and contamination abuse. } \\
\text { - Improve program-wide contamination plan: buy precision cleaned } \\
\text { components, clean and verify clean assemblies, verify that all fluids and } \\
\text { GSE introduced to systems are clean. }\end{array}$ \\
\hline Dynatube fluid fitting repairs. & - Seal saver design minimizes leakage at dynatube fittings interfaces. \\
\hline Zero-fault tolerant vernier thrusters & $\begin{array}{l}\text { - Vernier thrusters were an add-on and after thought for Shuttle. Vernier } \\
\text { capability and fault tolerance should be evaluated for all potential } \\
\text { missions on future vehicles. } \\
\text { - Consider more efficient injectors as compared to the Shuttle single } \\
\text { doublet vernier design to mitigate FORP. }\end{array}$ \\
\hline $\begin{array}{l}\text { Ground operation issues: } \\
\text { High ground processing timeline, } \\
\text { cost, hazards (hot R\&R, fire), } \\
\text { supportability and obsolescence. }\end{array}$ & $\begin{array}{l}\text { - Closely track removal rates, repair times, spares counts, limited life } \\
\text { hardware, and status of repair agencies. } \\
\text { - Consider a non-toxic propellant architecture to decrease costs, hazards, } \\
\text { and processing time. } \\
\text { - Implement Integrated vehicle Health Monitoring system (IVHM) and } \\
\text { expert systems. } \\
\text { - Implement on-board OMS engine bi-propellant valve cavity drain/purge. } \\
\text { - Relocate system components to the pod outer mold line and/or add } \\
\text { quick component access doors to avoid the need to remove the whole } \\
\text { pod for troubleshooting. } \\
\text { - Change component and panel installation from welded to dynatube-like } \\
\text { where possible. } \\
\text { - Few area heaters (vs. large number of local heaters) are far easier for } \\
\text { ground checkout. }\end{array}$ \\
\hline
\end{tabular}




\section{Fuel Cells and Power Reactant Storage Distribution (PRSD) subsystem:}

The low temperature alkaline fuel cell (AFC) power plant consists of a 96-cell stack and an accessory section. The accessory section regulates reactant flow, manages the product water, regulates the temperature of the stack, and monitors multiple data parameters such as cell voltage, reactant flow rates, and potassium hydroxide (KOH) levels. There are three fuel cell powerplants on each Orbiter, located in the forward part of the midbody under the payload bay liners. All three fuel cells are capable of providing 2-10 kW nominal power (16 kW max) with voltage regulation between 27.5 - 32.5 VDC. These powerplants are each connected to one of the Orbiter electrical buses, Main Buses A, B, and C, and handle the load required by that bus as controlled by the Electrical Power Distribution Control (EPDC) subsytem. The reactants required by the fuel cell (oxygen and hydrogen) are stored in four or five (varying by mission requirements) Power Reactant Storage Distribution (PRSD) tanks, also located in the mid body

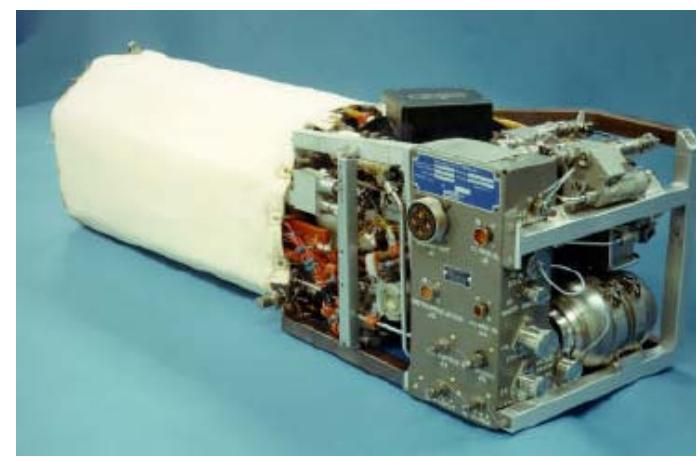

Figure 24: Orbiter Alkaline Fuel Cell

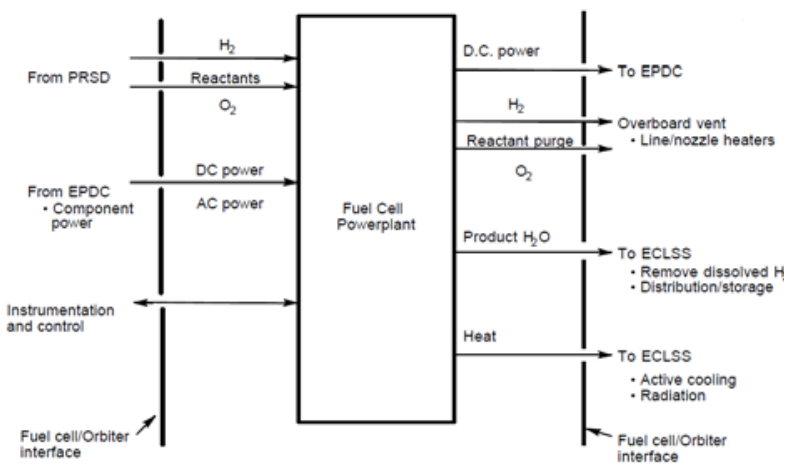

Figure 25: Basic Fuel Cell Powerplant Schematic

of the Orbiter. The water produced by the fuel cell is delivered to the Environmental Control and Life Support System (ECLSS) for use in both the cooling system and for crew consumption (Fig. 24-25).

The first major in-flight fuel cell issue arose during STS-2 when FC1 had to be shut down less than five hours into the flight. At mission elapsed time (MET) +02:27, the crew reported that FC1 pH sensor reported off scale high; due to other pressing issues, the crew was unable to perform all of the contingency operations to confirm the $\mathrm{pH}$ level. Over the next two hours, FC1's load-sharing decreased from a nominal 33\% to 26\%, indicating that the other fuel cells were picking up the load of the struggling fuel cell. At this point, flight controllers were concerned that possible $\mathrm{KOH}$ crossover might have occurred in the fuel cell and considered the fuel cell lost. The FC was then shut down and reactant valves were closed. Though the Orbiters are certified to land with only one working fuel cell, the failure of one results in a minimum duration flight (MDF). Once FC1 was shut down, the flight team became concerned that the isolated inter-cell potentials might be capable of water hydrolysis, producing free $\mathrm{H} 2$ and $\mathrm{O} 2$ and a potentially explosive situation; FC1 was restarted with the reactant valves still closed so that any remaining reactants in the stack would be consumed. This concern and safing procedure was new to the control team and had never been exercised during any mission simulations nor was it reflected in the onboard malfunction procedures for the crew. The team quickly learned that there should always be a plan to safely shut down and isolate any piece of hardware or even entire systems, particularly systems involving volatile reactants.

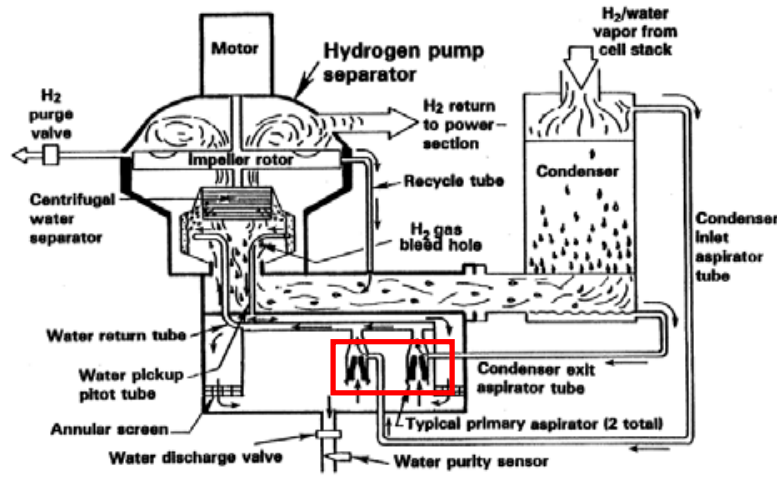

Fig 26: H2 Pump Separator schematic; aspirator tubes highlighted in red square

Post-flight, it was determined that an H2 pump aspirator orifice (Fig. 26) was plugged with some contamination particle and that, without a properly working water separation system, the fuel cell had flooded. The aspirator was replaced with a recycle line, and filter screens were added to keep out contamination. Further, realizing that there was not enough insight into how the water separation system was functioning, the team added an $\mathrm{H} 2$ pump motor sensor that would indicate motor failure. Further, the team added a bus-tying procedure to the flight rules that would 
standardize tying two fuel cells and their buses together at any indication of a potential fuel cell failure. This not only prematurely configures the buses in case of a fuel cell shutdown, but also allows the flight controllers to assess the health of a fuel cell by monitoring the load sharing between multiple fuel cells.

The second major issue occurred during the pre-launch activities of STS-4. FC1's condenser exit temperature (TCE) shifted downward $8^{\circ} \mathrm{F}$ when the fuel cell loads were ramped up to their high loads at T-20min for launch. The mission continued with no adverse mission effects. Post-flight, it was determined that fluid entrapment blocked a relief slot in the TCE valve causing the low temperature reading shift. In order to diagnose these problems sooner in the launch-flow, a high load calibration was built into the fuel cell activation timeline; on all subsequent flights, all three fuel cells were taken to high loads (about $8 \mathrm{~kW}$ each) for 30 minutes to ensure proper operation for launch.

During the post-landing activities of STS-43, helium was ingested into the $\mathrm{O} 2$ line causing a performance loss in FCs 2 \& 3. An incorrect GSE regulator setting allowed helium into the O2 system. The ground crew performed emergency power down procedures in order to shut down and safe the fuel cells before more damage could be done to the cells. These emergency procedures, however, assumed that the Orbiter was connected to ground power (as it usually is during pre-launch activities and again some hours after landing); in this case, the Orbiter had not yet been connected to a ground power supply. By shutting down and safing FC1, the only nominal fuel cell, the ground team left themselves without enough power on the Orbiter to throw the switches to isolate FCs $2 \& 3$ from their buses. Without sufficient power left to isolate, shut down, and safe the fuel cells, they continued to create power for the buses and consumed all of the reactants within the cells. The helium inside the cells continued to degrade the stacks; the fuel cells were lost and had to be removed from the Orbiter.

This incident led to the "Best-Last" rule when powering down fuel cells: in order to ensure that the Orbiter retains enough potential ( $28 \mathrm{~V}$ for the Orbiter) to isolate the fuel cells safely, the worst performing fuel cell should be shut down first, then the next worst, and finally the best fuel cell. Further, the ground team learned a lesson about evaluating emergency procedures to ensure that they always address the situation and configuration present. Emergency procedures should attempt to plan for all possible catastrophes and configure hardware to an absolute safe position. Proper procedure planning should aim to minimize the amount of unplanned reactions to unplanned events.

In preparation for NASA's plan to build an orbiting space station to which the Orbiter would dock, the fuel cell team brainstormed ways in which this configuration might affect the FC/PRSD subsystem; if the shuttle were to dock to some sort of larger station, it would lose its attitude flexibility and thus some of its passive heating strategies. The flight control team saw that this could create a potential problem if one of the fuel cells had been shut down and then needed to be restarted in this possibly "cold" configuration. From these misgivings, the STS-54 detailed test objective (DTO 412) arose in which a planned FC shutdown/restart occurred. On flight day 6, FCs 1 and 3 were purged in order to ensure their best performance while FC2 was shutdown. MN A and MN B were tied and connected to FC 1 while FC3 remained connected to MN C. After ten hours, FC 2 was restarted without any issues. It is stack-out temperature had decreased $60^{\circ}$, and the stack only required seven minutes of heating before it was ready for load. It was noted that during its shutdown, FC 2 sustained a $0.15 \mathrm{~V}$ performance loss which, because a cold cathode activation cannot be performed on-orbit to recover the loss, was permanent for the rest of the mission. This important demonstration gave the fuel cell community confidence that a fuel cell could be shut down and restarted in a space environment and provided flexibility when planning future missions.

From the first shuttle flight, a cell performance monitor (CPM) was used as a basic tool to gauge the health of the fuel cell stack. The CPM performed a self-test every seven minutes and reported the delta voltage for each of the fuel cell's 32-cell substacks. If this delta value rose significantly during the flight, it would be an indication that there was uncontrolled mixing of hydrogen and oxygen within the cells, a condition called "crossover," a mode of total failure for the fuel cell. For almost as long as the CPM has been a feature of the fuel cell system, it has passed along abnormal readings and false self-test failures. Various causes for failures including circuit shorts, cracked resistors, capacitor leaks, and unexplained anomalies were all noted. Despite the sporadic failures, the CPM often corrected itself, and good data regarding the fuel cell's health was available at least intermittently. For instances of CPM failure, a procedure was developed to bus-tie the suspect fuel cell to a healthy one in order to monitor its performance via load-sharing information. 
During the STS-83 mission, however, a small loss in performance in one of FC2's substacks generated an abnormal CPM reading which could not be explained away as an occasional CPM failure. The delta voltage values continued to trend upward as the mission progressed and, without further insight into the cells' health, crossover had to be assumed by the flight team. On the second day of the mission, FC2 was safed and then powered down while FCs 1 and 3 took over the loads for the remainder of the mission. With the loss of FC2, STS-83 became an MDF mission and landed just four days after launch. Post-flight, it was determined that there was no actual crossover of reactants in FC2 and that the CPM had only indicated the small performance loss experienced in a few cells. Because of this instance, the Fuel Cell single cell Monitoring System (FCMS) was developed and first used on STS87. FCMS takes voltage measurements of each individual cell before fuel cell activation occurs all the way through ground-power disconnect just moments before launch. These values can give the pre-launch teams the confidence they need to launch in case of bad CPM readings. Once in orbit, the FCMS data has been taken at least once by the crew to ensure continued health of the cells and could be taken again at any time throughout the flight if needed. The lesson is that redundancy in performance metrics can be just as important as redundancy in system operations.

In addition to changes that arose from issues encountered throughout the program, many technology and operations improvements were implemented as the demands on the fuel cell grew due to longer missions, more crew members, and dockings at the International Space Station (ISS). One of the first improvements in the program involved changing the stack from a 64-cell to a 96-cell stack by adding a third 32-cell substack. This addition increased the power capability from $10 \mathrm{~kW}$ to $12 \mathrm{~kW}$, supporting a higher power profile for the Orbiter. Further, this addition added some redundancy in case of a loss of one of the powerplants as the other two fuel cells would be able to pick up more load between them.

An operational improvement that took place over many missions was certifying the fuel cells to run through longer intervals without being purged. Initially, the flight rules specified that the fuel cells needed to be purged every eight hours in order to rid the stacks of the inerts that would build up and degrade performance. As flight controllers became more comfortable with the fuel cells' performance through many days in-orbit, they began to stretch the limits of the purge interval over multiple flights. By the end of the 30-year program, the fuel cells could be purged every 96 hours or when a $0.2 \mathrm{~V}$ decay had been observed, whichever came first. On flights when the Orbiter docked to station and received power from the ISS, the purge interval was raised to 120 hours or a 0.3V decay. By increasing the purge intervals, the team was able to decrease the complexity of operating the fuel cells as well as decrease some crew time from having to perform the manual purges. NASA learned that fuel cells can maintain steady performance for many days at a time and that performance drops of 0.2 or $0.3 \mathrm{~V}$ can be almost fully recovered by a two minute pulse purge.

The Space Shuttle was most often utilized in its last 10 years of operations as a construction vehicle that hauled pieces of the enormous ISS into orbit. Since much of its time on these missions was spent docked to the station, it seemed logical to design a way for the Orbiter to draw power from the massive solar panels and batteries of the ISS. These solar panels enjoy the renewable resource of sunlight as their power source whereas the shuttle's fuel cells have a limited amount of cryogenic reactant on board. By being able to run the fuel cells at their minimum power of about $2 \mathrm{~kW}$, the team would be able to increase their cryogenic margins and remain in orbit for 2-3 extra days. These added days allowed critical time for extra-vehicular activities (EVA) or other work on the ISS.

The system that connected the Orbiter power system to that of the ISS was called the Station to Shuttle Power Transfer System (SSPTS). This system was able to increase the docked duration from about 6-8 days to approximately 9-12 days by transferring responsibility of up to $8 \mathrm{~kW}$ of the Orbiter's load to the ISS. This power transfer was achieved by adding two power transfer units (PTUs) to the Orbiter which converted the 120VDC input power from the station to 28VDC expected by the main buses (Fig. 27).

SSPTS capability was installed on OV-103 (Discovery) and OV-105 (Endeavour) and was first attempted with success on STS-118. Each flight of OV-103 and OV-105 afterwards involved using SSPTS to lengthen the docked missions.

Since the ISS was able to handle most of the Orbiters' power needs, the fuel cells ran at their minimum value $(2 \mathrm{~kW})$ on-orbit. On some fuel cells that had higher operating hours, the sustaining heater was triggered due to a low stack output temperature. This heater nominally came on for 1-4 minutes until the output temperature raised enough to trigger an OFF signal. Some fuel cells saw zero sustaining heater cycles while on SSPTS while others saw up to 
220 cycles. Age of the fuel cell and power requirement (lower power output meant lower operating temperature) were the two biggest factors relating to the number of sustaining heater cycles.

The Fuel Cell and PRSD subsystem lessons described above and several additional ones are summarized in Table 7.

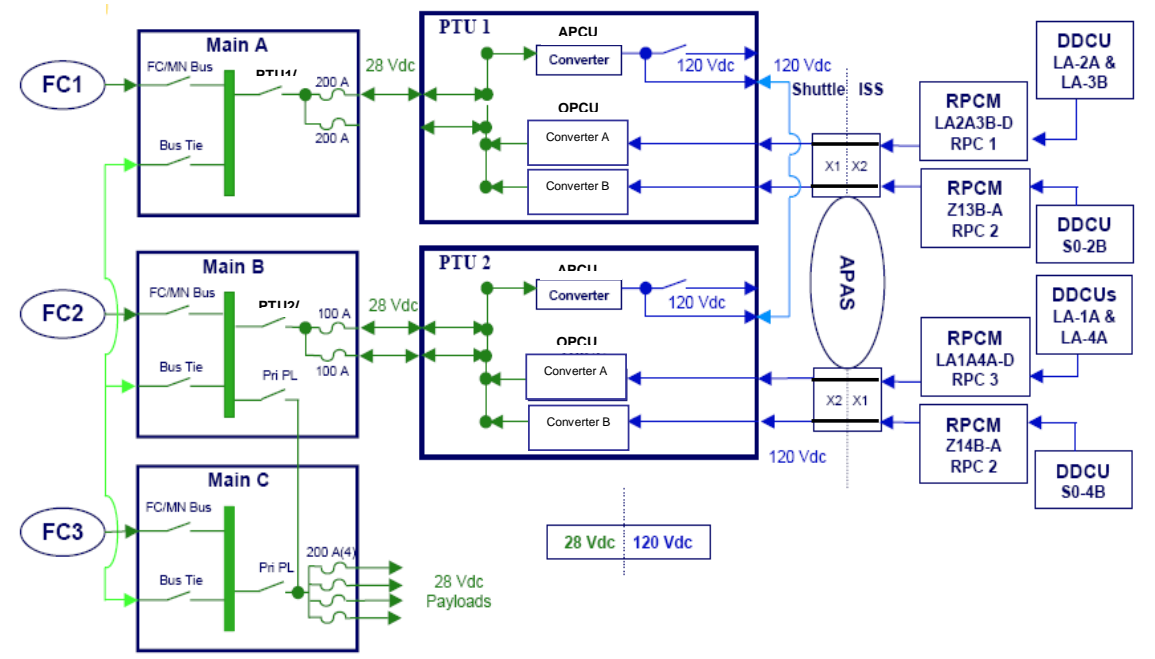

Fig 27: SSPTS Electric Architecture

Table 7: Selected lessons learned in the Fuel Cell/PRSD subsystem.

\begin{tabular}{|c|c|}
\hline Problem Description & Lesson learned \\
\hline $\begin{array}{l}\text { STS-2 FC1 shutdown } \\
\text { following H2 } \\
\text { pump/water separator } \\
\text { failure and FC flooding. }\end{array}$ & $\begin{array}{l}\text { - Bus-tying the suspicious fuel cell with a healthy fuel cell is the method for } \\
\text { monitoring performance of the suspect fuel cell when one fuel cell picks up the } \\
\text { load from another. } \\
\text { - For vital systems, redundancy in monitoring the system's health is as important } \\
\text { as it is in the system itself. }\end{array}$ \\
\hline $\begin{array}{l}\text { STS-4 condenser exit } \\
\text { temperature downward } \\
\text { shift. }\end{array}$ & $\begin{array}{l}\text { - Validate all instrumentation at maximum loads by running the fuel cells at high } \\
\text { power for approximately 30min shortly after fuel cell activation. }\end{array}$ \\
\hline $\begin{array}{l}\text { Pre STS-69 condenser } \\
\text { exit temperature } \\
\text { overheat. }\end{array}$ & $\begin{array}{l}\text { - Fuel Cell can not maintain normal conditions without cooling. } \\
\text { - } \quad \text { Procedures need to guarantee vehicle/FC coolant connections. }\end{array}$ \\
\hline $\begin{array}{l}\text { STS-43 post-landing: } \\
\text { fuel cells left on bus } \\
\text { without water removal } \\
\text { capabilities. }\end{array}$ & $\begin{array}{l}\text { - Operation timelines and procedures must be developed, executed and verified to } \\
\text { avoid potential permanent damages to systems. } \\
\text { - Cells can provide power when Fuel Cell is off. }\end{array}$ \\
\hline $\begin{array}{l}\text { Fuel Cell exposure to } \\
\text { high humidity. }\end{array}$ & $\begin{array}{l}\text { - Residual KOH on outer cell surfaces due to previous cell fill procedure can turn } \\
\text { into a black sludge when the KOH absorbs water vapor. } \\
\text { - Sludge causes shunt current effect across the cells but is reversible if not too wet. } \\
\text { - Stack assembly procedures should take care to to contain } \mathrm{KOH} \text { inside the stack. }\end{array}$ \\
\hline $\begin{array}{l}\text { Fuel Cell shutdown and } \\
\text { restart in mid-flight. }\end{array}$ & $\begin{array}{l}\text { - Redundant power systems need to be designed and proven in a space } \\
\text { environment, i.e., shutdown/restart capability. }\end{array}$ \\
\hline $\begin{array}{l}\text { STS-83 FC shutdown } \\
\text { due to perceived } \\
\text { crossover. }\end{array}$ & $\begin{array}{l}\text { - Residual oxygen in cells after an incomplete purge can create abnormal corrosion } \\
\text { processes which requires single-cell voltage measurements to detect. } \\
\text { - When vital instrumentation has a history of being erratic, a redundant } \\
\text { measurement (such as FCMS data) must be available to rule out failures. } \\
\text { - When failure can neither be proved, nor disproved in-flight, it is better to } \\
\text { perform safing procedures and eliminate the risk of an unplanned failure. }\end{array}$ \\
\hline
\end{tabular}




\begin{tabular}{|c|c|}
\hline Problem Description & Lesson learned \\
\hline $\begin{array}{l}\text { Port plugging (inability } \\
\text { to clear inerts due to cell } \\
\text { corrosion buildup). }\end{array}$ & $\begin{array}{l}\text { - All materials within the system need to be indentified for potential particles } \\
\text { - } \quad \text { Carboase and must include system Failure Mode and Effects Analysis (FMEA). } \\
\text { of fiberglass/epoxy FC frame. } \\
\text { - Importance of maintaining system cleanliness. } \\
\text { - } \quad \text { Port plugging can be discovered during N2 diagnostic testing. } \\
\text { pan still fly with some port plugging so long as performance is monitored and } \\
\text { purges are performed when necessary. }\end{array}$ \\
\hline $\begin{array}{l}\text { Cell Performance } \\
\text { Monitor (CPM) failures. }\end{array}$ & $\begin{array}{ll}- & \text { Certain EEE part failures are not detected byCPM self-check. } \\
\text { - } & \text { For suspected CPM failures, bus-tie to a good FC and monitor load sharing. }\end{array}$ \\
\hline $\begin{array}{l}\text { Water relief line freeze } \\
\text { possibility. }\end{array}$ & $\begin{array}{l}\text { - } \begin{array}{l}\text { Operating environments need to be identified, implemented in design, performed } \\
\text { and evaluated. } \\
\text { - When new mission configurations arise (e.g., docking to a station), new } \\
\text { problems may also arise which might require re-evaluation of risks. }\end{array} \\
\end{array}$ \\
\hline $\begin{array}{l}\text { Cracking in fuel cell } \\
\text { insulator plates (Noryl). }\end{array}$ & $\begin{array}{l}\text { - } \begin{array}{l}\text { Any machining process should be evaluated for its effect on the material's } \\
\text { structural integrity. } \\
\text { - }\end{array} \\
\text { Components should be routinely checked for degradation. }\end{array}$ \\
\hline $\begin{array}{l}\text { STS-115 loss of phase in } \\
\text { coolant pump and } \mathrm{H} 2 \\
\text { pump. }\end{array}$ & $\begin{array}{l}\text { - Three-phase electrical motors need to be evaluated and tested for being able to } \\
\text { operate in two-phase. } \\
\text { - Verified that the FC pumps could operate in flight on two phases; additional } \\
\text { purges were necessary to maintain 2-phase operation. }\end{array}$ \\
\hline $\begin{array}{l}\text { H2 vent capped during } \\
\text { STS-38 checkouts. }\end{array}$ & $\begin{array}{l}\text { - System maintenance and pre-operation checklist procedures must be executed } \\
\text { and verified prior to system startup. } \\
\text { - } \quad \text { FC regulators are unable to function if vents are capped. } \\
\text { H2 overpressure can damage the internal cells and irreparably damage the fuel } \\
\text { cell. }\end{array}$ \\
\hline $\begin{array}{l}\text { H2 pump current sensor } \\
\text { sensitivity. }\end{array}$ & $\begin{array}{l}\text { - Unusual sensor activity can indicate a trend toward failure of the H2 pump } \\
\text { motor, and thus a subsequent loss of the fuel cell. } \\
\text { - When using an instrumentation measurement as a failure indication, make sure } \\
\text { that all causes for output variations are understood and that procedures are in } \\
\text { place for filtering out actual failure indications. }\end{array}$ \\
\hline $\begin{array}{l}\text { Voltage pin sharing (cell } \\
\text { voltage pin resistance } \\
\text { fluctuations) }\end{array}$ & - $\quad$ Add solder to the wire-to-pin crimp to complete conductive bond at connection. \\
\hline $\begin{array}{l}\text { STS-127 long sustaining } \\
\text { heater cycle. }\end{array}$ & 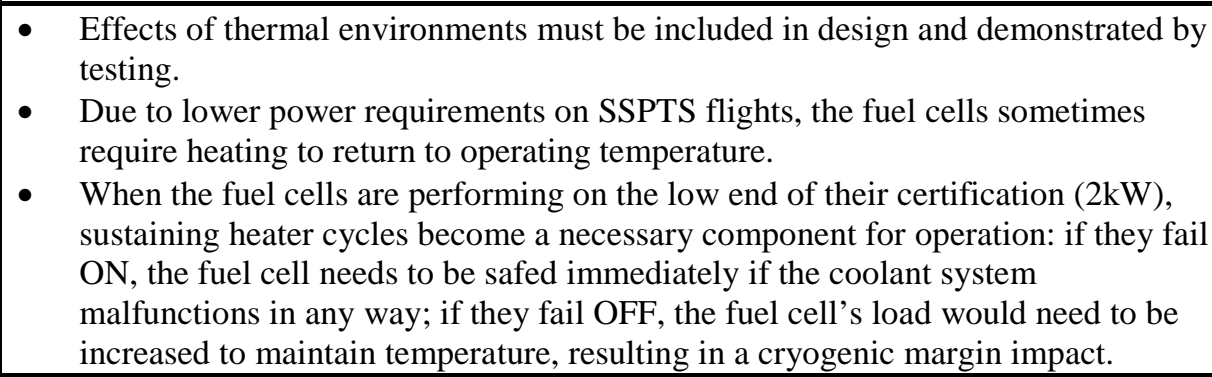 \\
\hline $\begin{array}{l}\text { Multiple O2/H2 } \\
\text { flowmeter erratic } \\
\text { readings and failures } \\
\text { (shifts in calibration, } \\
\text { zero output, full-scale } \\
\text { output, constant output). }\end{array}$ & $\begin{array}{l}\text { - } \quad \text { Fluid flow path must be external to the electronic and instrumentation housing. } \\
\text { - Sometimes, the cost and time required to redesign a troublesome component } \\
\text { outweighs the benefit. } \\
\text { - So long as a flowmeter still accurately indicates a purge, it will also accurately } \\
\text { indicate a significant leak. }\end{array}$ \\
\hline
\end{tabular}




\section{Electrical Power and Distribution and Control Wiring:}

The Electrical Power Distribution and Control (EPD\&C) subsystem consists of a three-bus system that distributes electrical power (24V to $32 \mathrm{~V}$ ) from the fuels cells to the forward, mid, and aft sections of the Orbiter. The EPDC system consists of wires, circuit breakers, resistors, fuses, diodes, remote switching devices, and bus bars (Fig. 28). The EPDC system also includes three $120 \mathrm{~V}, 400 \mathrm{~Hz}, 3$-phase, alternating current (AC) power busses, generated by sets of 750volt-ampere (VA) inverters from the main busses.

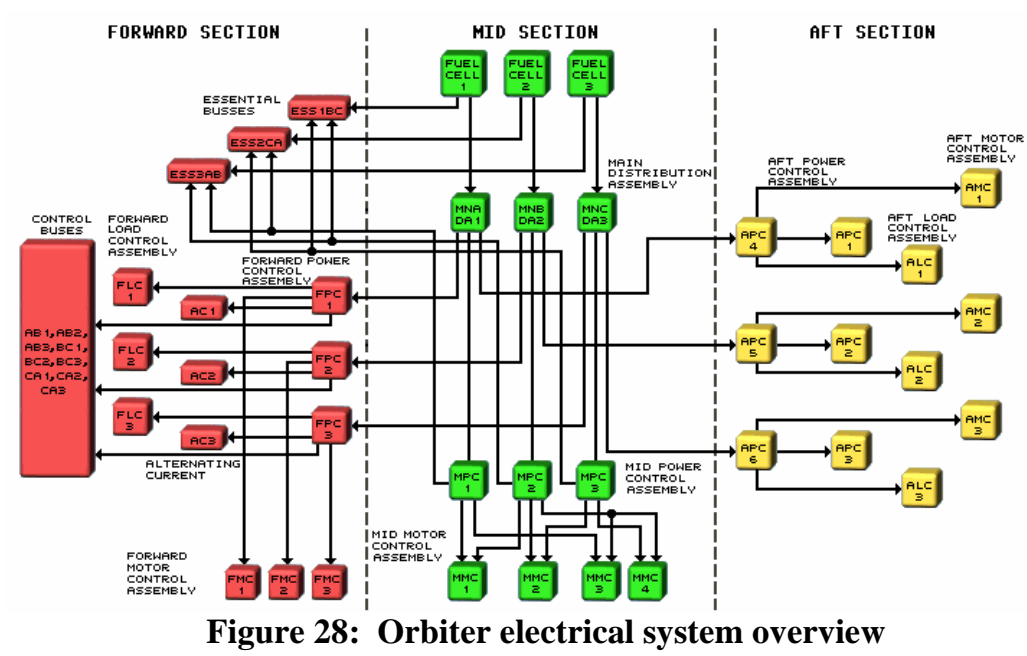

The Electrical Wiring and Insulation Subsystem (EW\&I) is made up of all electrical wiring and connectors external to subsystem boxes except for certain unique coaxial cables associated with communications equipment. This subsystem encompasses approximately 600 harnesses, 7,000 connectors, 120,000 wire segments and 228 miles of wire (Fig. 29).

On a series of missions (STS-75, STS-78, STS-79, STS-80 and STS81) fuses associated with the cryogenic tank heaters, holding cryogenic hydrogen and oxygen, opened with no evidence of a short circuit or high currents. Investigation showed that the fuses were subjected to many cycles in which they carried currents close to their rating. This caused repeated thermal cycles which mechanically stressed the fusable link. This stress eventually caused the fuses to mechanically open (KaymenHalsey Effect). A design change was implemented that replaced the 5-

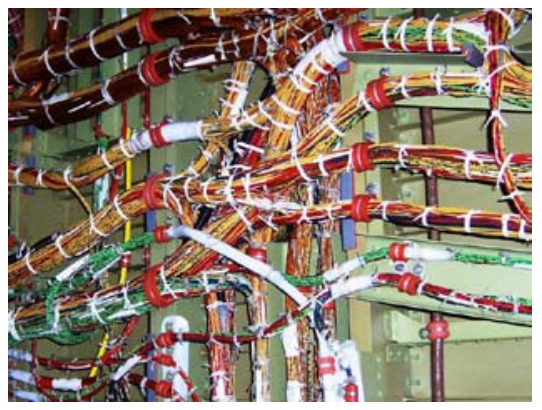

Figure 29: Examples of Orbiter wiring. amp fuses with 10-amp fuses and there were no reoccurrences.

On STS-28, a short circuit occurred on a 20-gage cable powering the teleprinter through the aft crew cabin panel A15 utility outlet. The crew had reported seeing sparks and glowing embers coming from the cable at the panel. The utility outlet circuit breaker did not open to isolate the short because of the low amount of energy of the short. Data showed that the short continued to propagate for 1.5 seconds. Inspection of the damaged cable revealed that both the power and the return were melted into two pieces at the connector, and 3/4 of an inch of the Gortex cover was melted. The wiring was melted to 1.2 inch from the wire tie on the stain relief up to the connector until the two wires were no longer touching; evident arcing had taken place. The connectors were exposed when the wires from a straight connector were bent at 90 degrees to fit into the recessed area, cracking the Kapton (polyimide) insulation.

Industry experience with this phenomenon shows that the arc propagates when the heat generated by the arc chars (pyrolizes) the adjoining insulation which can now conduct electrical current and generate heat to cause further charring. In a wire bundle, the charring can spread between circuits, causing the

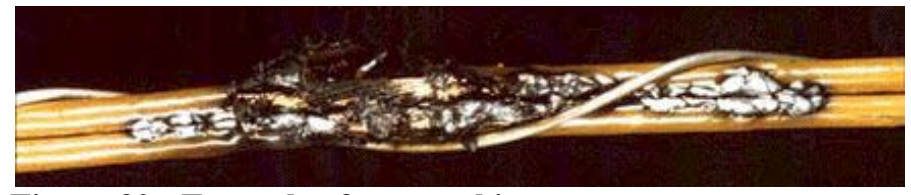

Figure 30: Example of arc tracking

American Institute of Aeronautics and Astronautics 
failure of the whole bundle. Polyimide insulation was selected for shuttle wiring because of weight savings and the superior mechanical properties of polyimide. Covering polyimide insulation with a layer of PTFE (Teflon) reduces the likelihood of arc tracking (Fig. 30). In the shuttle, the risk of arc tracking was reduced by inspecting wire for damage that could start arcing and identifying critical circuits with high voltage differences and routing them in separate wire bundles so that arc faults would not affect redundant functions.

On STS-31, during the power up for Flight Control System (FCS) checkout, the Air Data Transducer Assembly (ADTA) \#3 circuit breaker was closed but showed no signs of power. The circuit breaker was cycled five times. Three of these times, the LRU showed power, but following final closure, the power was off. The circuit breaker was cycled an addition five times, and ADTA\#3 regained power and functioned nominally the remainder of the flight. There have been many $(>10)$ occurrences of similar circuit breaker malfunctions (fail to conduct upon closure) during flight and on the ground. Multiple failure analyses have concluded that the failure mode is nonconductive debris interrupting continuity between the fixed and moveable contacts. This debris is generally small particles of the Circuit Breaker body's molding resin, and is generated when the circuit breakers are cycled (Fig. 31). The circuit breaker construction does produce a small amount of contact wiping action which can clear contamination. A workaround to ground occurrences (implemented in the OMRSD) is to cycle the circuit breaker until it operates. Unfortunately this also

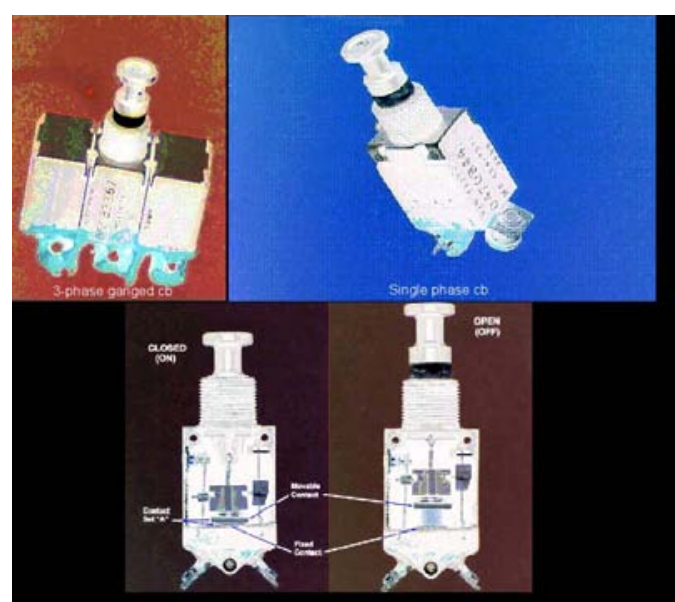

Figure 31: CBs used as power switches and redundant controls. Not a good practice. generates more internal debris. The failure rate has been tracked and is increasing but never reached unmanageable levels.

During STS-36 prelaunch ground operations, AC2 phase A inverter had numerous voltage spikes and current fluctuations in a 2-minute period. The inverter was removed and replaced and retest was nominal. The failed unit was sent to vendor for failure analysis. The problem was isolated to a lose connection caused by four loose screws (improperly torqued). Other suspected units were inspected and found to also have loose screws. These other units were removed and replaced.

On the STS 51-B mission, when the right ET umbilical door was closed on orbit, a motor (B2) in the door drive actuator was inoperative. In postflight inspection, the problem was isolated to a loose/separated electrical connector. Most probable cause was failure to fully engage the pin/ramp locking feature when re-mating the connector. Difficult access and limited visibility due to connector location could have contributed to this condition. New standards of conformation of the connection were initiated.

During the STS-65 mission (OV-102), the Spacelab experiment AC bus lost power when it was switched from the Orbiter inverter to the unpowered Spacelab experiment inverter. The Spacelab experiment AC bus was regained 3 minutes later by reconnecting it back to the Orbiter inverter. There was no impact to the mission; the AC bus was recovered. Personnel may have inadvertently bumped the AC bus switch on cockpit panel R7 to the experiment inverter position.

On STS-93, a short circuit occurred in the AC system during ascent that caused the loss of the primary controller on the center main engine and the secondary controller on the left main engine. Post-mission inspection found a damaged wire in one of the payload bay wire trays. The failure analysis revealed that the conductor was exposed because of mechanical impact; something striking the wire harness against a screw that had raised burrs on the head (Fig. 32). As a result of this failure, extensive vehicle wiring inspections were performed. As a result of the inspections, many other incidents were found of damaged wires and improperly protected wire harness.

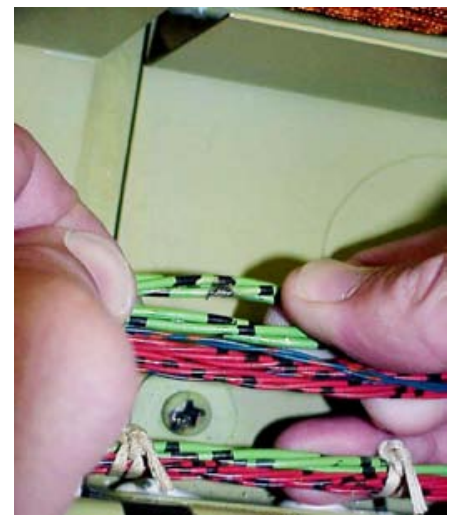

Figure 32: STS-93 wire short 
The EPD\&C, wiring and insulation lessons are summarized in Table 8.

Table 8: Selected lessons learned in the EPD\&C, wiring and insulation subsystems.

\begin{tabular}{|c|c|}
\hline Problem Description & Lesson Learned \\
\hline $\begin{array}{l}\text { Vehicle wire damage due to ground } \\
\text { maintenance activity. }\end{array}$ & $\begin{array}{l}\text { - Important to perform specific detailed closeout inspection after work on } \\
\text { cables or connectors. } \\
\text { - Wiring is easily damaged by nearby work activity. } \\
\text { - Training of personnel is critical both to prevent damage and to detect } \\
\text { damage. } \\
\text { - Wire chafe protection is important. }\end{array}$ \\
\hline STS-4 Heater fuse failure. & $\begin{array}{l}\text { - Repetitive thermal cycles on a fuse can cause it to mechanically open } \\
\text { - Space and usage environments must be considered for fuse de-rating. }\end{array}$ \\
\hline STS-28 teleprinter short (arc fault). & $\begin{array}{l}\text { - Kapton wire insulation has unique failure mode, not anticipated to } \\
\text { manifest in shuttle environment. } \\
\text { - Arc faults do not necessarily cause currents high enough to trip circuit } \\
\text { protection. } \\
\text { - Fault propagated toward power source until distance between wire } \\
\text { increased. }\end{array}$ \\
\hline STS-93 wire short. & $\begin{array}{l}\text { - Ground maintenance and vehicle modifications can cause damage like } \\
\text { burrs on screw heads that lead to later wire damage. } \\
\text { - Closeout inspections did not focus on inspecting the wiring. } \\
\text { - Formalized and more clearly defined wire inspection criteria and } \\
\text { processes. Perform periodic wiring inspections; particularly inspect for } \\
\text { previously undetected wiring discrepancies. } \\
\text { - Separate critical redundant wire runs and/or install barrier materials to } \\
\text { protect against the effects of arc tracking. } \\
\text { - Widespread use of chafe protection has greatly reduced wire damage. } \\
\text { - Enhanced workforce awareness and training is paramount in ensuring } \\
\text { the health of electrical wiring. }\end{array}$ \\
\hline Lightning monitoring system. & $\begin{array}{l}\text { - Low frequency bus voltage monitoring systems are inadequate for } \\
\text { detecting lightning transients on vehicle power busses. } \\
\text { - In order to detect lightning transients, monitoring system frequency } \\
\text { response should be higher than lowest resonant frequency of vehicle } \\
\text { power bus. } \\
\text { - Low level signals easily couple onto bus from distant strikes, several } \\
\text { miles away. } \\
\text { - Pulse energy rather than voltage magnitude is a useful tool for assessing } \\
\text { damage (Wunsch-Bell). }\end{array}$ \\
\hline Personnel switch bumps. & $\begin{array}{l}\text { - Redundancy of controls and inhibits important for critical functions. } \\
\text { - Utilize switch guards. }\end{array}$ \\
\hline Circuit breaker problems. & $\begin{array}{l}\text { - Cycling circuit breakers recovers function. } \\
\text { - Debris is created from internal wear on circuit breakers. } \\
\text { - Avoid use of CBs as power switches and redundant controls. }\end{array}$ \\
\hline $\begin{array}{l}\text { Bus voltage transients due to nearby } \\
\text { lightning strikes }\end{array}$ & $\begin{array}{l}\text { - Solid state remote power controllers do not isolate loads from bus } \\
\text { transients as effectively as electromechanical relays. This is true of } \\
\text { MOSFET based controllers as well as transistor based ones. }\end{array}$ \\
\hline
\end{tabular}




\section{Space Shuttle Pyrotechnics:}

Pyrotechnics are explosive devices that contain energetic mixtures of fuel and oxidizer compounds that when activated by electrical or mechanical initiation converts chemical energy to mechanical energy. Since, these units contain their own fuel and oxidizer they are ideal for use in the vacuum environment of space. Pyrotechnic devices

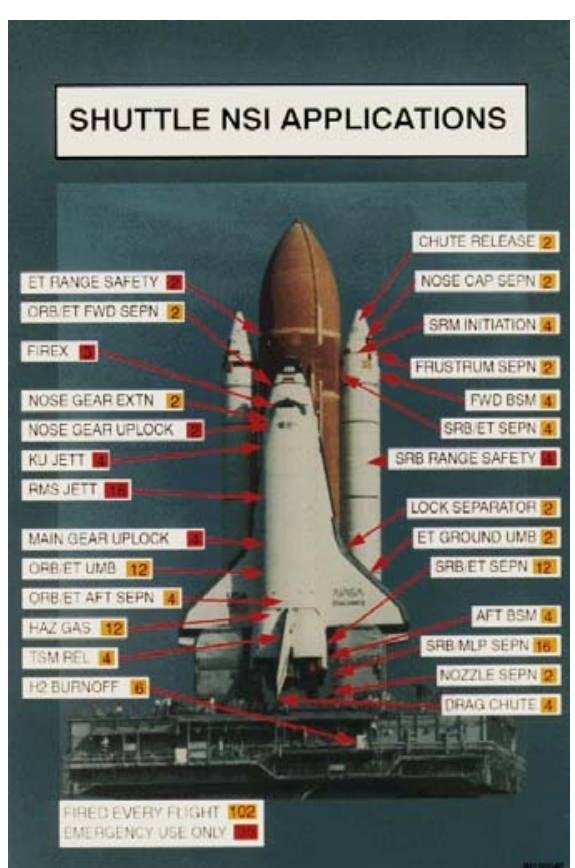

Figure 33: Shuttle pyrotechnic devices were used throughout the Space Shuttle vehicles and on payloads because of numerous functions requiring high reliability, minimum weight, high energy density, precision timing and low cost. These devices provide the greatest amount of energy per unit mass, unit volume and dollars of any actuator that exists today. They can be used to perform in-flight applications and controlled tasks automatically or manually with the aid of simple electrical circuits or triggers.

Some of the many functions that pyrotechnics performed on the Shuttle include booster ignition, stage separation, satellite deployment, fire suppression, thrust termination, landing gear deployment, crew escape, pressurization and control of fluid systems, equipment release and jettison, parachute deployment, opening and closing electrical circuits, battery activation, timing and delayed function, and cable cutting (Fig. 33). The fact that it's extremely rare that a component from a flight qualified lot of Pyrotechnic devices has malfunctioned on missiles, rockets and spacecraft systems in the past is evidence that explosive and pyrotechnic devices can perform all the above mentioned functions, safely and reliably. To ensure safety, NASA requires that $10 \%$ of a production lot be subjected to environments and test fired at a range of temperatures. Also, units are serialized and have complete traceability from materials, manufacturing processes to final delivery. Although pyrotechnic devices are one-shot units, they are used redundantly (two units for a single function) meaning that the flight system has single fault tolerance.

At least fifty (50) Government Furnished Equipment (GFE) pyrotechnics devices have been certified for human spaceflight by NASA-Johnson Space Center pyrotechnic engineers. These units include the NASA Standard Initiator (NSI), NASA Standard Detonator (NSD), several types of power pressure cartridges, mild detonating fuse and detonating cords, shear bolts, explosive bolts and frangible nuts, guillotines, reefing line cutters and other devices. About 140 NSIs were flown on each Shuttle flight. There were over 13,750 NSI fired during flight on the shuttle vehicles without a failure, with a reliability of 0.9999 at a confidence level of $95 \%$. The qualification, certification, performance, and other pertinent information is contained in NSTS-08060, Space Shuttle System Pyrotechnic Specification. Selected lessons learned in the Shuttle pyrotechnic hardware are briefly described below and summarized in Table 9.

During the STS-8 flight in 1983, the primary piston of the Nose Landing Gear (NLG) Extension Thruster was found on the runway threshold at Dryden Flight Research Facility (DFRC). It had been ejected from the housing of the thruster. Trajectory analyses determined that the piston had been fired from its centerline position for the nose gear release system without opposing force from the NLG strut and it had traveled between the two nose gear tires. Engineering studies dictate that the destruction of either of the NLG tires results in destruction of the 2nd tire and landing/rollout capability is lost. It was determined that o-ring leakage and "stickage" had resulted in the loss of "captured" air pressure behind the piston when the assembly is driven shut during NLG retraction at KSC and also that the single compressed internal spring was not physically adequate to forcibly extend the piston to a fully stroked safe position prior to firing. Without being able to fully extend prior to firing when the NLG has deployed solely from gravity, the piston end-of-stroke-stabilizing-shoulder will shear off during firing and be ejected from the housing as was the case. This condition was not considered during the original design and was not required during qualification testing. The lesson learned is to make sure that the hardware design and qualification testing account for all potential flight conditions. In addition, never assume contained air pressure is available as an assist to pyrotechnic performance. 
Multiple 31/2 frangible bolt SRB hold down nut stud hang-ups have occurred during Shuttle flights. A firing skew between redundant cartridges caused small amounts of aluminum to be "shaved" from the SRB skirt bores when the redundant cartridge fired "late" and allowed the retained stud to drag through the bore prior to release from the nut. The NASA Safety Engineering Center (NESC) investigated the problem and designed a pyrotechnic Shielded Mild Detonating Cord (SMDC) crossover firing line between the redundant cartridges to reduce the firing skew and prevent stud hang-up. The lesson learned is to be sensitive to the firing skew present in all redundant pyrotechnic systems.

Pyrovalve gas sampler failures have occurred during several Shuttle flights. These pyrovalves are part of the Orbiter Aft Fuselage Gas Sampler System (OAFGSS) which consists of two standalone racks located in the Orbiter aft compartment. Each rack contain three Vacuum Bottle Assemblies (VBA) and all electrical components required to fire the pyrovalves in flight. Post-flight analysis of the gas provides an estimate of Integrated Main Propulsion System (MPS) leakage by measuring aft fuselage hazardous gas concentrations during ascent. Typical failures result in the normally opened valve failing to close and trap hydrogen gas. Given the low criticality of the hardware, plus the fact are six gas samplers flown during each Shuttle flight, there was never any mission impacts due to valve failures to seat properly after firing/actuation. Failure analyses show that debris and manufacturing dimensional variations in the valves were the main contributors to the failures. (Fig. 34).

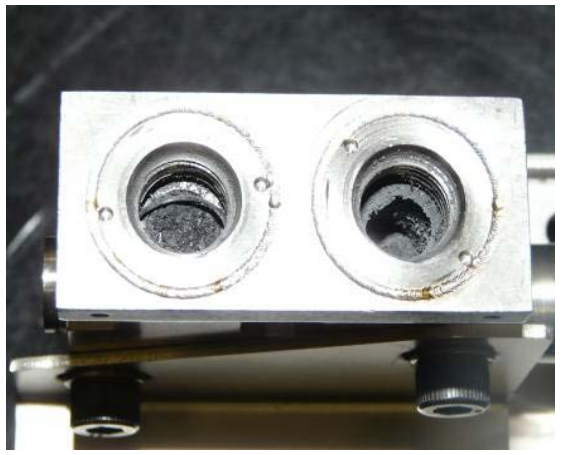

Figure 34: Pyrovalve (post-fire) showing result of failure.

During a lot acceptance tests of the NASA Common Pressure Cartridge, the pressure outputs were observed to be lower than required. An investigation revealed that changes in the manufacturing process of the propellant mix contributed to the lower pressures. The specific powder propellants (Hercules 6573 and 5808), had begun to deteriorate after several years of storage. Changes in the manufacturing processes had occurred that were not evident during the commercial certification of the material.

During lot acceptance testing on the Orbiter/External Tank $2 \frac{1}{2} 2$ inch frangible nut, the nut failed to separate during a single booster cartridge firing. Investigations into the processing of the Inconel 718 alloy revealed that smaller grain structures had been obtained during raw material fabrication to meet the grain structures desired for jet turbine engine fan blades, the primary users of Inconel 718. Inconel alloy 718 is used to fabricate all NASA frangible nuts $\left(3 / 4,1 \frac{1}{2}, 2 \frac{1}{2}\right.$ and the $31 / 2$ inch). NASA revised their specification requirements to allow for an average grain size no finer than ASTM 7 using the radial forged (GFM) process. NASA also re-designed the booster cartridge to provide a greater margin of performance. The lesson learned is to be aware of raw material processing "refinements" over time which occur to satisfy other primary material users and to specify maximum as well as minimum material properties in applications that are sensitive like separation systems. Margin requirements are also sometimes underestimated.

Table 9: Selected lessons learned in the Space Shuttle pyrotechnic subsystem.

\begin{tabular}{|l|l|}
\hline Problem Description & Lessons learned \\
\hline ThS-8 ejected Nose Landing Gear Extension & $\begin{array}{l}\text { - Verify that hardware design and qualification testing account } \\
\text { for all potential flight conditions. } \\
\text { - Never assume contained air pressure is available as an assist } \\
\text { to pyrotechnic performance. }\end{array}$ \\
\hline $31 \frac{1}{2}$ inch frangible nut skew firing. & $\begin{array}{l}\text { Be sensitive to the firing skew present in all redundant } \\
\text { pyrotechnic systems. }\end{array}$ \\
\hline Pyro-valve poppet failure. & $\begin{array}{l}\text { Debris in bore and/or manufacturing dimensional variations } \\
\text { can cause pyrovalve to not properly seal after firing/actuation. } \\
\text { The NSI is an initiator and should not be used as a pressure } \\
\text { cartridge, e.g., use NSI plus booster pressure cartridge. }\end{array}$ \\
\hline Propellant powder deterioration. & $\begin{array}{l}\text { Changes in the manufacturing processes had occurred that } \\
\text { were not evident during the commercial certification of the }\end{array}$ \\
\hline
\end{tabular}




\begin{tabular}{|l|l|}
\hline Problem Description & Lessons learned \\
\hline & material. \\
\hline Inconel alloy 718 became stronger and harder & $\begin{array}{l}\text { Be aware of raw material processing "refinements" over time } \\
\text { to break. }\end{array}$ \\
& which occur to satisfy other primary material users. Need for \\
& control of material grain sizes (e.g., roll milling). \\
& $\begin{array}{l}\text { Need to specify both minimum and maximum material } \\
\text { properties, particularly in applications that are sensitive like } \\
\\
\text { separation systems. }\end{array}$ \\
\hline
\end{tabular}

\section{Summary and Conclusions:}

The development, design, certification and operation of the SSP Orbiter power and propulsion subsystems have provided a wealth of lessons learned for future spacecraft applications, both re-usable and expendable vehicles. A subset of these have been discussed in this paper for the following Orbiter subsystems: APU, Hydraulics, Water Spray Boiler, Mechanical Flight Controls, Main Propulsion System (MPS), Fuel Cells and PRSD, OMS and RCS, EPDC, electrical wiring and pyrotechnics. There are both specific hardware lessons as well as general lessons that apply across all subsystems. Among the common relevant lessons are:

1. Importance of a thorough and integrated mission-representative qualification test program with production flight hardware to fully understand all interfaces and their combined interactions as well as the value of performing off-nominal testing. This will ensure that design sensitivities are identified early. Down time between missions or exposure time effects should be considered a well. However, it is important to keep in mind that no test can perfectly duplicate the actual operational conditions and good tests results are no reason for complacency.

2. A re-design to solve a design flaw is more cost-effective than continuous maintenance as a solution to an on-going problem. However, verification of the validity of operational limitations is preferred over redesign, if proven acceptable.

3. Importance of having a full understanding of the operational environment.

4. System improvements, corrective actions for other problems, process changes, and/or mission requirement changes can bring unintended consequences or unexpected sensitivities. Recognize that requirements change with the changing space environments and those need to be accounted for in the future designs. For many Orbiter systems, the environment in which the hardware operates changed with the evolution of the Program. It is important to periodically review the operational environments for impacts to hardware certification, using flight failures as a guide on where to focus.

5. Important to design critical systems to be fail-safe and to verify that redundant elements are truly independent.

6. Implement a robust program-wide contamination control plan, including: buying precision clean components, clean and verifying clean assemblies, and verifying all fluids introduced to the system are clean before connecting.

7. Importance of a robust and thorough Corrective Action process that avoids extensive latitude for accepting repeated failures without preventive corrective actions.

8. Establish periodic and preventative maintenance, inspection and checkout plan for critical flight hardware to reduce the likelihood of failures. Checkout testing intervals should be set based on component criticality and system functionality requirements.

9. Establishing a fleet leader test program. Fleet leader testing have offered the Space Shuttle Program great utility to work flight and/or hardware problem resolution, uncover problems early, GSE development and checkout and design changes independent of vehicle flow. This will be even more crucial for expendable programs where the flown hardware is not available for failure analysis.

10. Trending of hardware operational flight and ground test data to uncover any out-of-family or degraded performance, well before they become critical, i.e., trend data for any shifts but not necessarily violating limits and comparing data from flight to flight.

11. Always verify the system integrity after any intrusive work is performed on the vehicle.

12. Design systems for ease of leak checking and operational verification.

13. Importance of maintaining an experienced/skilled ground crew. 
In addition to all these, the importance of good record keeping cannot be stressed sufficiently enough. This is sometimes hard to judge; since there are many instances where information dating back well over 30 years ago has been extremely useful and applicable to understanding and solving current problems. All programs should establish an effort to retain, catalog and permanently store data such that can be easily retrieved in the future.

Lastly, it is critical among all subsystems to maintain contacts with their hardware suppliers. Engineers should always be aware of the status of suppliers in case they are needed at any time. Periodic face-to-face contact, e.g., annual Technical Interchange Meetings (TIM) between the NASA customers and the hardware suppliers has proven extremely valuable over the history of the Space Shuttle Program.

It is the hope of the authors that all the propulsion and power lessons presented in this paper be useful in future spacecraft vehicle applications.

\section{Acknowledgments}

Special thanks to Mr. Stan Barauskas (Boeing Huntington Beach) for his invaluable help on APU lessons learned; from his 38 years of exceptional design support from the Apollo Program through the Space Shuttle APU design and complete operational use. Thanks to Mr. Shahram Namvari and Mr. Al Saberi for their assistance on hydraulic and Water Spray Boiler lessons. Thanks also to Mr. Phil Cota for his help in MPS subsystem. We appreciate the assistance of Mr. John Applewhite for his input in OMS/RCS historical lessons and Mr. James T. Johnson for his help in the pyrotechnics section.

\section{References}

${ }^{1}$ Lance, R., Weary, D., “Space Shuttle Orbiter Auxiliary Power Unit Development Challenges”. Unpublished paper. Conference held at JSC, June 1983.

${ }^{2}$ Shuttle Ops MMACS Volumes II and III: APU and Hydraulic Anomalies, Design History, JSC-28922, 2007.

${ }^{3}$ Martinez, H.E., Albright, J.D., et al., "Lessons Learned from the Design, Certification, and Operation of the Space Shuttle Integrated Main Propulsion System (IMPS), AIAA, 2011.

${ }^{4}$ Martinez, H.E. and Welzyn, K.J., "Lessons Learned from the Space Shuttle Engine Cutoff System (ECO) Anomalies:, AIAA, 2011.

${ }^{5}$ Martinez, H.E., Albright, J.D., et al., "Lessons Learned from the Space Shuttle Engine Hydrogen Flow Control Valve Poppet Breakage”, AIAA, 2011.

${ }^{6}$ Hauver, S.E., and Sueme, D.R., "Evaluation of a Fracture Failure Mode in the Space Shuttle Hydrogen Pressurization System Flow Control Valves,” AIAA 92-3373, 1992.

${ }^{7}$ McLaughlan, P.B., Forth, S.C., and Grimes-Ledesma, L.R., Composite Overwrapped Pressure Vessels, A Primer”. NASA/SP2011-573.

${ }^{8}$ Engineering Charts by EP2/John Applewhite, 2/22/95, RCS Primary Thruster Tiger Team Operations Review. Unpublished.

${ }^{9}$ PRCB charts by EP4/Michael McNeely, 5/22/97, PRCS Thruster Oxidizer Valve Failures - Tiger Team Recommendations Status. Unpublished.

${ }^{10}$ WSTF Investigative Report WSTF-IR-0996-001-04, "Reaction Control System Primary Thruster Fuel Valve Pilot Seal Extrusion Exposure Test,” April 5, 2005.

${ }^{11}$ Corrective Action Record 108RF01, WSTF CAE Terence Kelly, 8/22/2006, Primary Thruster Fuel Valve Extrusion. Unpublished.

${ }^{12}$ Corrective Action Record AE2702, WSTF CAE Terence Kelly, 8/25/2006, Primary Thruster Fuel Valve Water Response Test and Current Trace Screening. Unpublished.

${ }^{13}$ WSTF Investigative Report WSTF-IR-0996-001-04, "Reaction Control System Primary Thruster Fuel Valve Pilot Seal Extrusion Exposure Test,” April 5, 2005.

${ }^{14}$ Egil Console Handbook, Systems Division Electrical Systems Branch, JSC-12830, Revision F PCN-2, June 8, 2007.

${ }^{15}$ Utley, Kenneth, N., Arc-Tracking and Wire Insulation Pyrolization, website of Space Environment and Experiments Branch: NASA GRC. Unpublished. 



\section{Agenda:}

- Introduction and Approach

-Subsystems Overview

- Selected Subsystems Problems and Corresponding Lessons ${ }^{1,2}$

- Summary and Conclusion

$\checkmark$ Common lessons across subsystems

${ }^{1}$ The accompanying paper provides a more comprehensive list of lessons and references.

${ }^{2}$ The symbol is used to indicate specific Lessons. 


\section{Introduction}

There is a wealth of lessons in the $\sim 40$ year history of the Space Shuttle Orbiter. In the present briefing, only selected or "key" lessons are presented in the areas of Orbiter Propulsion and Power. These subsystems include:

- Auxiliary Power Unit (APU)

- Orbiter Hydraulics

- Water Spray Boiler (WSB)

- Mechanical Flight Controls (MFC)

- Main Propulsion System (MPS)

- Orbital Maneuvering System (OMS) and Reaction Control System (RCS)

- Fuel Cell and Power Reactant and Storage Devices (PRSD)

- Electrical Power Distribution and Control (EPDC), Wiring and Insulation

- Pyrotechnics and Pyrotechnic Devices

\section{Approach:}

- Few or selected "key" lessons presented, in the judgment of the authors.

- i.e., it is impossible to cover all or even most of all lessons.

- The most popular historical failures do not necessarily provide the best lessons. Unexplained anomalies do not typically have lessons.

- Focus on lessons that have potential application to future programs. 


\section{Auxiliary Power Unit (APU) Lessons}

APU Subsystem Overview:

- 3 independent monopropellant grade hydrazine fueled APUs.

- Through catalytic decomposition, transmit the mechanical power to drive the 3 hydraulic pumps.

- APU subsystem consists of the APU unit, the hydrazine fuel tanks and distribution lines, injector water cooling system, drain system, exhaust duct and APU controller

\section{Selected Problems and Lessons:}

- STS-9 APU 1 and 2 fires during entry and APU detonations post landing caused by stress corrosion cracking in GG injector stems.

- Reduce installation and removal stresses on critical materials; monitor if necessary.

- Reduce residual carbon and stresses from manufacturing process.

- Implement periodic inspections (e.g., borescope) and maintenance plan based on critical parameters and expand as data/experience is gathered.

Conduct qualification or fleet lead program to uncover time-related problems.

- Change to a chromized-layer injector also brought up the unintended consequence of nitriding/flaking of chromium layer.

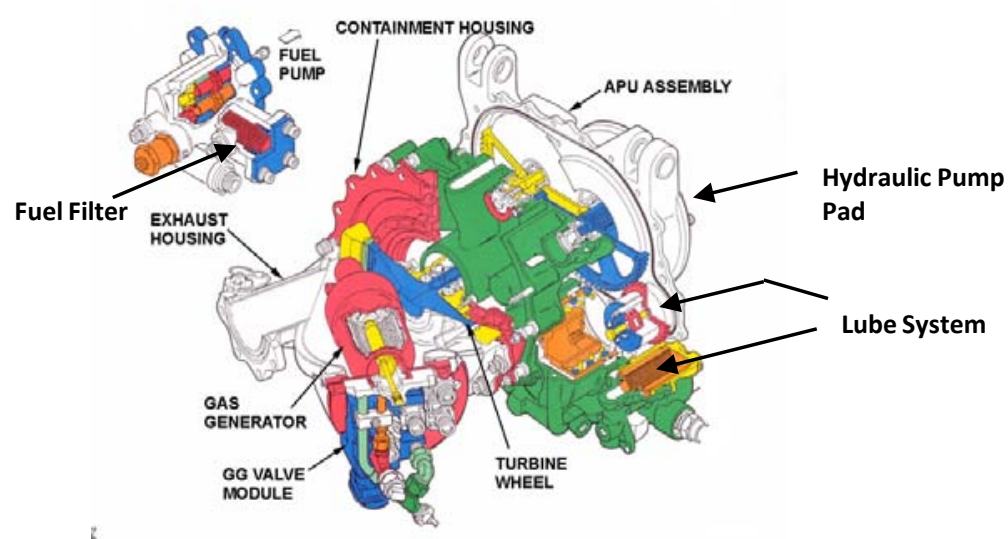

Orbiter APU Unit

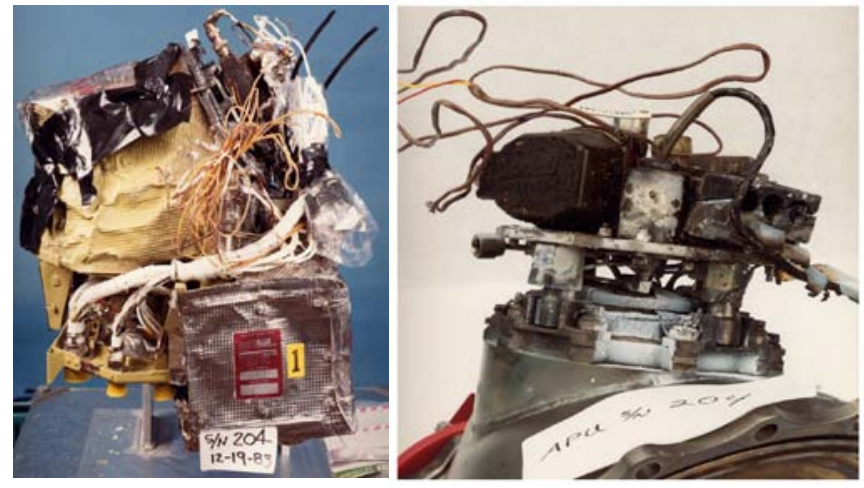

Damaged APU from STS-9

- See following pages for additional lessons 


\section{Auxiliary Power Unit (APU) Lessons}

\begin{tabular}{|c|c|}
\hline Problem & Lessons \\
\hline $\begin{array}{l}\text { Hot re-start explosion } \\
\text { during Qual testing. } \\
\text { Adiabatic Bubble } \\
\text { Compression } \\
\text { Detonation (ABCD) }\end{array}$ & $\begin{array}{l}\text { Design solutions to correct the cause are preferred over solutions that treat the symptom. } \\
\text { - Assure safe emergency capability with design changes and operational constraints. } \\
\text { fuel system to minimize bubble formation. } \\
\text { - Importance of high-altitude thermal vacuum testing. } \\
\text { Avoid metal-to-metal contact as ignition source in hydrazine. } \\
\text { Reduce time between hydrazine fuel servicing operations and launch. }\end{array}$ \\
\hline 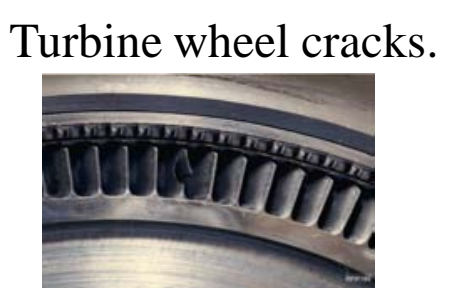 & $\begin{array}{l}\text { Incorporate a full-width shroud to support blade profile. } \\
\text { Perform periodic NDE (e.g., penetrant inspections). } \\
\text { inspection criteria after the finish is completed. }\end{array}$ \\
\hline $\begin{array}{l}\text { STS-1 Gas Generator } \\
\text { heaters A and B failed } \\
\text { due to gas leak in } \\
\text { common cavity case. }\end{array}$ & $\begin{array}{l}\text { Verify that redundant elements are truly independent. } \\
\text { Improve inspection techniques. }\end{array}$ \\
\hline $\begin{array}{l}\text { Water cleaning process } \\
\text { change resulting in } \\
\text { GGVM seats cracks } \\
\text { and STS-31 scrub. }\end{array}$ & Carefully review all critical process changes; changes could bring more bad than good. \\
\hline $\begin{array}{l}\text { STS-79 speed sensor } \\
\text { mis-wire and APU } \\
\text { shutdown . }\end{array}$ & $\begin{array}{l}\text { - Hardware upgrades can bring unexpected sensitivities or unique set of problems. } \\
\text { - Consistent callouts across all levels of hardware drawings. }\end{array}$ \\
\hline
\end{tabular}




\section{Auxiliary Power Unit (APU) Lessons}

\begin{tabular}{|c|c|}
\hline Problem & Lessons \\
\hline $\begin{array}{l}\text { Gas generator } \\
\text { roughness due to voids }\end{array}$ & Utilize compression spring on gas generator to take-up voids as catalyst loss occurs. \\
\hline $\begin{array}{l}\text { Fuel Line Heater } \\
\text { failures on many } \\
\text { flights }\end{array}$ & \multirow{4}{*}{$\begin{array}{l}\text { Design solution is preferred over continuous maintenance. } \\
\text { Design propellant heating systems to mitigate the risk of heater failed ON condition or } \\
\text { shorts (Examples: self-regulating or self-limiting heaters, solid-state thermostats, } \\
\text { segmented coil valves, DC-DC converters for power and isolation, overtemperature } \\
\text { thermostats close to the beginning of the heaters, installing temperature sensors to monitor } \\
\text { fuel line temps). } \\
\text { - Bi-metallic disc thermostats are susceptible to wear damage in high vibe zones. } \\
\text { replacement or intrusive work and prior to flight. } \\
\text { failure probability to an acceptable minimum. }\end{array}$} \\
\hline 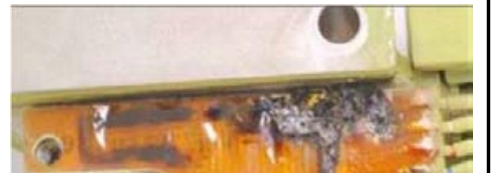 & \\
\hline $0 \quad\left(\begin{array}{lll}8 & 0\end{array}\right.$ & \\
\hline $\begin{array}{l}\text { STS-121 heater } \\
\text { burn through }\end{array}$ & \\
\hline $\begin{array}{l}\text { Exhaust duct leakage } \\
\text { and sensor failures }\end{array}$ & $\begin{array}{l}\text { Establishing a life limit on relatively inexpensive hardware that did not meet qualification } \\
\text { goals is sometimes more cost effective than re-design. } \\
\text { re-design to prevent failure. } \\
\text { - Feletion of frequently failing hardware that is no longer needed may be more costly than } \\
\text { - Final leak checks should be done under the most realistic operating conditions. }\end{array}$ \\
\hline $\begin{array}{l}\text { Hypergolic Quick } \\
\text { Disconnects (QDs) } \\
\text { leaks }\end{array}$ & $\begin{array}{l}\text { QDs should be selected and designed for ease of maintenance; reduce SCAPE operations. } \\
\text { repair/replacement. } \\
\text { - Heaters might be needed on hydrazine tank ullage lines and QDs. } \\
\text { - Periodic replacement of GSE filters. }\end{array}$ \\
\hline
\end{tabular}




\section{Orbiter Hydraulics Lessons}

\section{Hydraulic Subsystem Overview:}

- 3 independent hydraulic power systems which provide power to actuate aerodynamic flight control surfaces (elevons, body flap, rudder/speedbrake), main engine gimbals and valve controls plus end effectors.

\section{Selected Problems and Lessons:}

- On STS-76 ascent, a hydraulic system \#3 leak developed, with the leak rate increasing to $1 \% / \mathrm{min}$.

Always verify the system integrity after any intrusive work is performed on the hardware.

- Subjecting the component (e.g., flexhose) to vibrations could reveal a leak that could go undetected on the ground.

Design the system for ease of leak checking and integrity verification.

- Main Pump port cap to housing pulled out inserts due to incorrect use of bolts prior to STS-109.

Need adequate mandatory inspection points (MIP).

- Careful assessment of helical coil inserts, and torque requirements.

- Design critical joints to be: low maintenance, easy to inspect, prevent moisture intrusion/corrosion, high pullout strength, and preload consistency (nut factor).

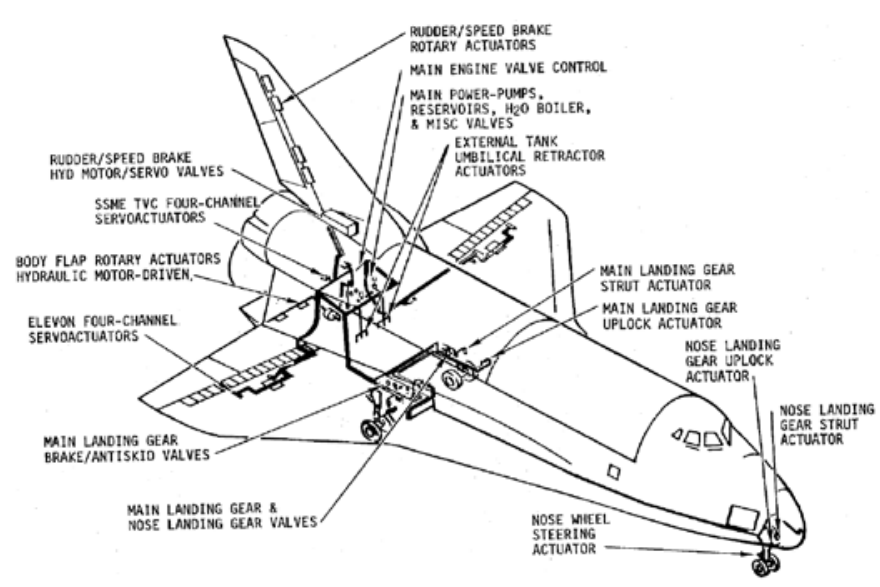

Orbiter Hydraulic Subsystem

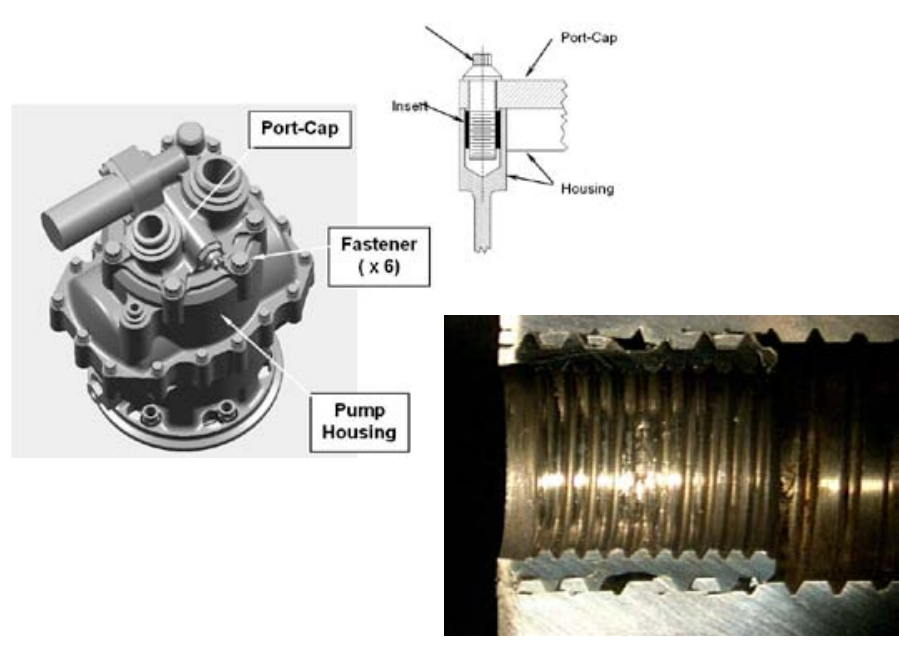

Main Pump port cap pulled out inserts 


\section{Orbiter Hydraulics Lessons}

\begin{tabular}{|c|c|}
\hline Problem Description & Lesson \\
\hline $\begin{array}{l}\text { Qualification tests of complex } \\
\text { hydraulic system, e.g., Flight } \\
\text { Control Hydraulic Laboratory } \\
\text { (FCHL) }\end{array}$ & $\begin{array}{l}\text { Essential to perform a comprehensive and integrated mission-representative } \\
\text { qualification testing with production flight hardware to fully understand all } \\
\text { interfaces and their combined interactions as well as off-nominal testing. }\end{array}$ \\
\hline $\begin{array}{l}\text { On STS-1, observed pressure } \\
\text { spikes in hydraulic system } 1 \text { and } 2 \\
\text { main pump output. }\end{array}$ & $\begin{array}{l}\text { Perform hydraulic dynamic testing and analysis with a flight representative } \\
\text { system. } \\
\text { over re-design, if proven acceptable. }\end{array}$ \\
\hline $\begin{array}{l}\text { RSB PDU spool stop } \\
\text { displacement prior to STS-101 } \\
\text { Hydraulic actuator power valve showing } \\
\text { displacement of 2-piece spool }\end{array}$ & $\begin{array}{l}\text { Avoid spool stop inserts, i.e., design valve with single spool stop. } \\
\text { Establish a maintenance plan to assess hardware condition and refurbish } \\
\text { degraded components. } \\
\text { Modification (OMM) at Palmdale, but there were no requirements to review } \\
\text { secondary } \Delta \mathrm{P} \text { data other than during Frequency Response Test. Lesson is to } \\
\text { always review of all critical parameter test data. } \\
\text { Freeze-plug technique successfully developed and implemented to perform } \\
\text { hydraulic hardware removals on the pad without need to drain or isolate the } \\
\text { hydraulic interface lines. }\end{array}$ \\
\hline
\end{tabular}




\section{Orbiter Hydraulics Lessons}

\begin{tabular}{|c|c|}
\hline Problem Description & Lesson \\
\hline $\begin{array}{l}\text { Hydraulic isolation valve } \\
\text { retainers unseated/displaced, } \\
\text { restricting movement. }\end{array}$ & $\begin{array}{l}\text { Be extra vigilant of internal valve retainers which can dislodge/displace and } \\
\text { restrict movement. } \\
\text { seated at all temperatures. } \\
\text { costly component R\&R. }\end{array}$ \\
\hline $\begin{array}{l}\text { TVC actuator drift due to lock } \\
\text { valve leakage causing surge } \\
\text { pressures. }\end{array}$ & - Match actuator command and position $\left(\leq 2^{\circ}\right)$ before hydraulic pump start. \\
\hline Piston accumulator leaks. & $\begin{array}{l}\text { Welded bellows accumulators have been better than piston accumulators for } \\
\text { preventing leakage. } \\
\text { Piston accumulator tend to self-generate more contamination. }\end{array}$ \\
\hline $\begin{array}{l}\text { Permaswage reducer tee fitting } \\
\text { cracks and leaks. }\end{array}$ & $\begin{array}{l}\text { Avoid side loads on hard lines during installation. } \\
\text { Utilize a more ductile material than titanium. } \\
\text { Perform periodic inspections. }\end{array}$ \\
\hline $\begin{array}{l}\text { Hydraulic system contamination } \\
\text { and silting causing multiple } \\
\text { failures/leaks. } \\
\text { Complexity/serviceability of } \\
\text { hydraulic systems. }\end{array}$ & $\begin{array}{l}\text { Important to implement strict contamination control requirements. } \\
\text { (e.g., elevons, TVC, ET umbilical actuators). } \\
\text { - Institute preventative maintenance of critical components. } \\
\text { - Install hydraulic QDs interface at the vehicle mold line. }\end{array}$ \\
\hline
\end{tabular}




\section{Water Spray Boiler Lessons}

\section{WSB Subsystem Overview:}

- 3 independent thermal control system that provide passive and active cooling capabilities to cool down hydraulic oil as well as the Auxiliary Power Unit (APU) lubrication oil.

\section{Selected Problems and Lessons:}

- WSB regulator leaks.

Select soft-good materials with higher strength and elasticity.

- Impose a tighter and cleaner ATP requirement at the vendors.

- Reduce gas supply filter size (e.g., 10 microns).

Avoid designs that require relief valve actuation as part of nominal system operation, particularly during the dynamic ascent phase.

- Continuously trend hardware data to uncover early any degraded performance.

- Water Spray Boiler freeze-ups on more than 30 flights and $>33 \%$ of units.

Avoid open to space vacuum cooling system where the cooling fluid pressure drops below its triple point; causing freeze-ups and blocking critical flow passages and orifices. Utilize a low vapor pressure cooling fluid.

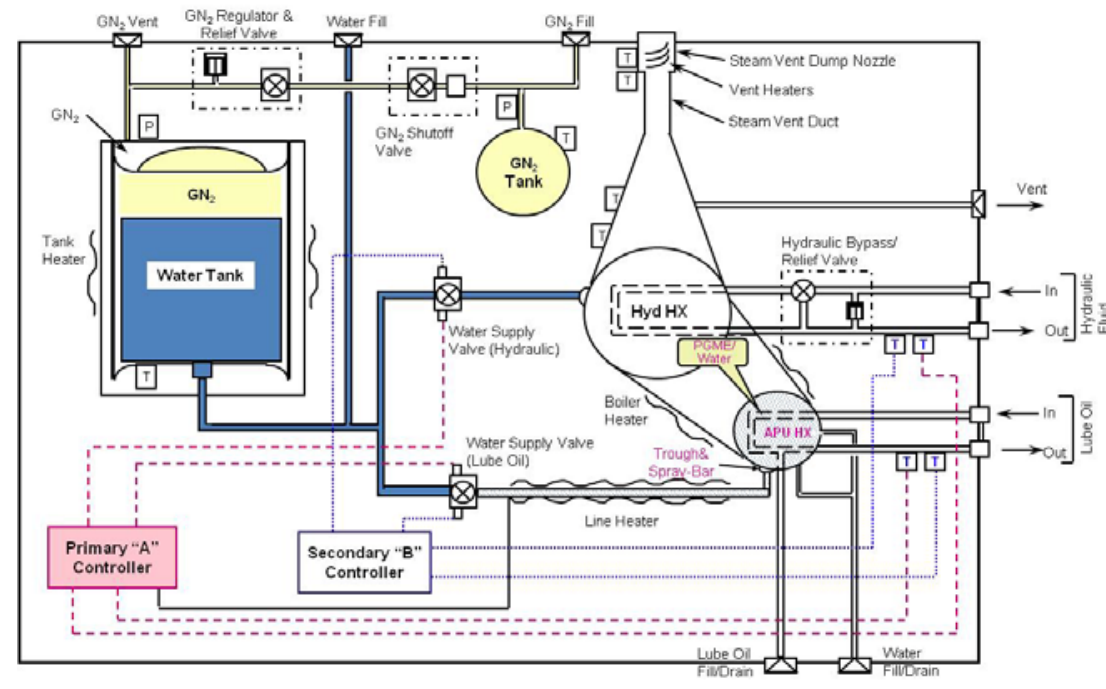

Water Spray Boiler

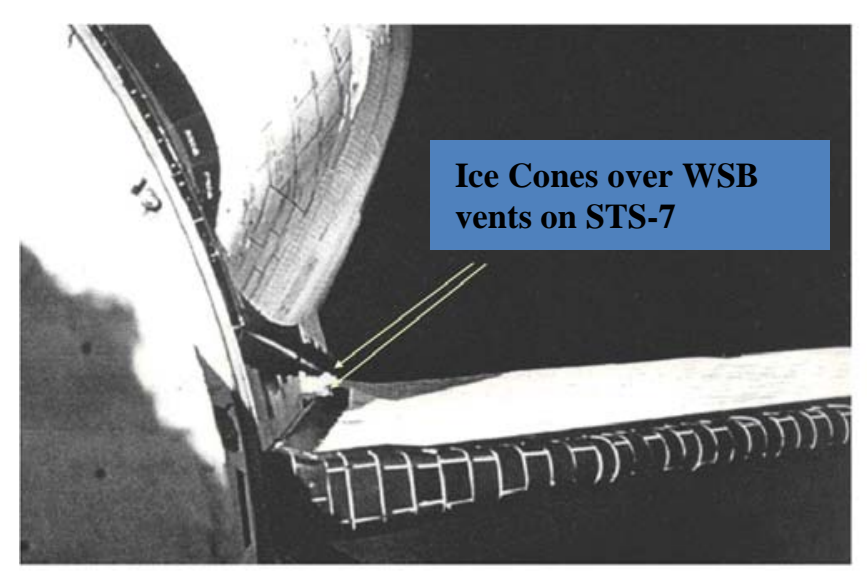




\section{Water Spray Boiler Lessons}

Simulated Ascent Test of WSB: 


\section{Water Spray Boiler Lessons}

\begin{tabular}{|c|c|}
\hline Problem Description & Lesson \\
\hline $\begin{array}{l}\text { Water valve leaks (e.g., E- } \\
\text { brite corrosion). }\end{array}$ & $\begin{array}{l}\text { Periodically inspect all critical welds. } \\
\text { - Perform double wrench torque test to verify bi-metallic joint integrity. }\end{array}$ \\
\hline $\begin{array}{l}\text { GN2 isolation valve failed } \\
\text { pressure decay due to } \\
\text { intergranular corrosion. }\end{array}$ & $\begin{array}{l}\text { - Utilize moisture-resistant filler materials on all welds. } \\
\text { moisture levels in GN2 systems. } \\
\text { - Reduce/control moisture levels in GN2 supply tanks. Periodically monitor/sample } \\
\text { Continuously trend hardware data to uncover early any degraded performance. }\end{array}$ \\
\hline $\begin{array}{l}\text { WSB heat exchanger } \\
\text { temperature sensor } \\
\text { limitations. }\end{array}$ & $\begin{array}{l}\text { Install independent dual-bead temperature sensors at each inlet/outlet of heat } \\
\text { exchangers. } \\
\text { - Use same location for the controller temperature sensors and downlisted sensors. } \\
\text { high quality copper content and grease. }\end{array}$ \\
\hline $\begin{array}{l}\text { Stycast cracks on component } \\
\text { seals. }\end{array}$ & $\begin{array}{l}\text { Replace the stycast with a less brittle glass base sealer, e.g., silicon-oxide, to } \\
\text { avoid paths/cracks for leaks and corrosion. }\end{array}$ \\
\hline $\begin{array}{l}\text { Water heat exchanger } \\
\text { container corrosion and } \\
\text { external leakage. }\end{array}$ & $\begin{array}{l}\text { Design water heat exchangers with galvanically compatible materials to mitigate } \\
\text { corrosion. } \\
\text { Be careful in addressing corrosion problems by use of coatings. }\end{array}$ \\
\hline
\end{tabular}

WSB Container Corrosion 


\section{Mechanical Flight Controls (MFC) Lessons}

\section{MFC Subsystem Overview:}

- Consists of the Rudder/Speedbrake and Body Flap actuation system:

- 4 Rudder/Speedbrake (RSB) actuators and drive shafts

- 4 Body Flap (BF) actuators and drive shafts

- 1 RSB Power Drive Unit (PDU)

- 1 Body Flap PDU, respectively

\section{Selected Problems and Lessons:}

- External corrosion, internal wear, and corrosion fretting of RSB and BF actuators.

Perform periodic external and internal maintenance inspections on all critical hardware for corrosion damage.

Establish a fleet leader inspection plan to assess the condition of the hardware over time and uncover any unexpected issues.

Apply corrosion-preventive primer (e.g., Super Koropon) to all external hardware surfaces.

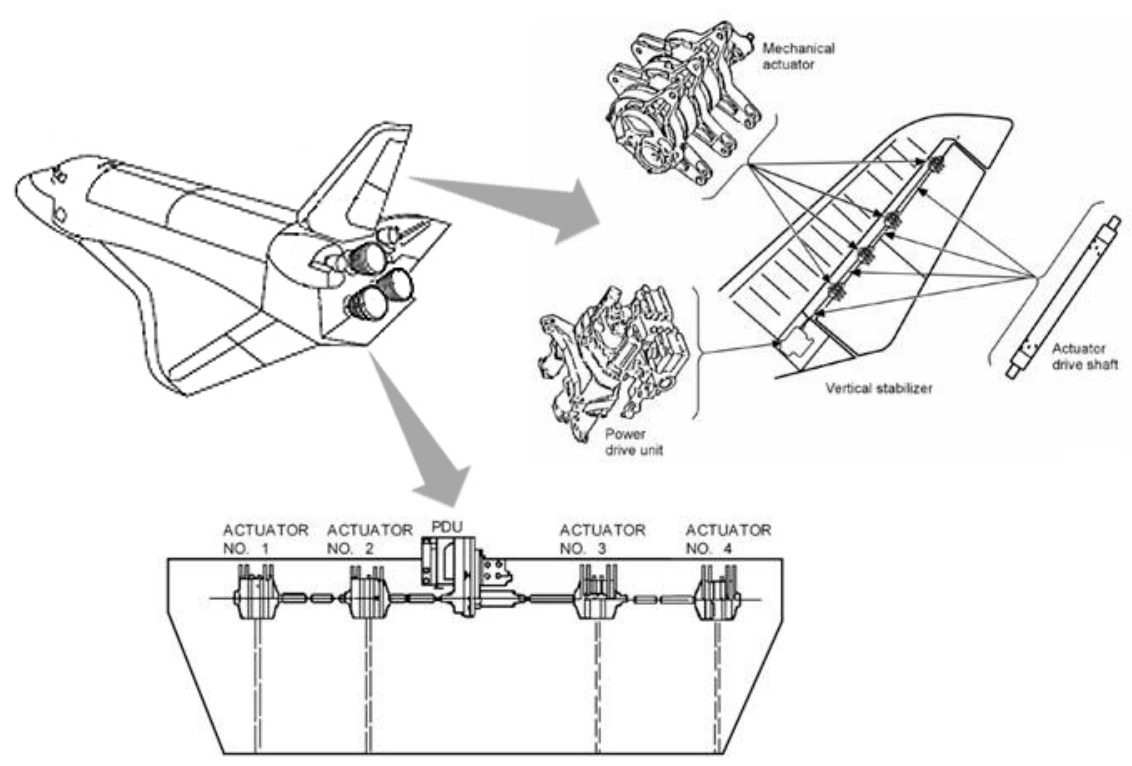

Rudder/Speedbrake and Body Flap actuation systems

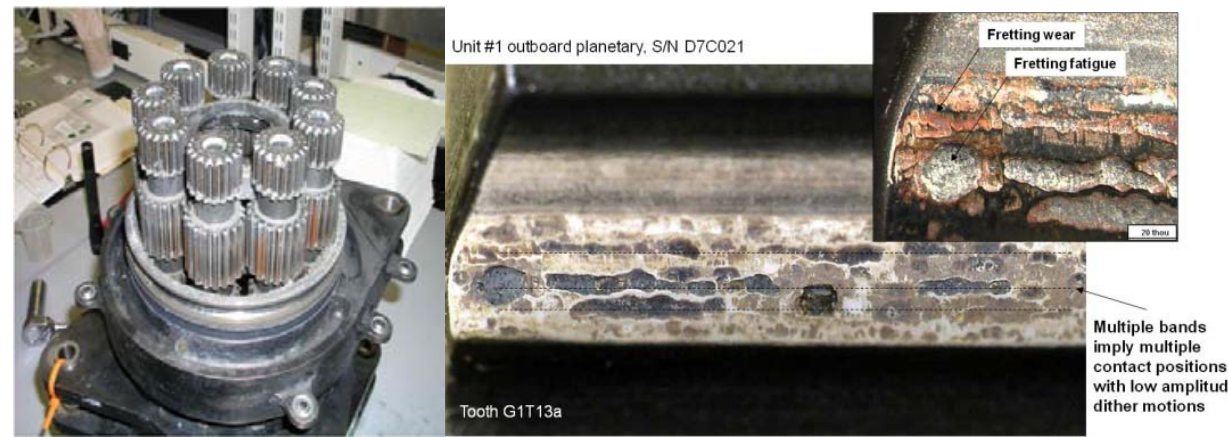

RSB actuator planetary gear corrosion damage. 


\section{Mechanical Flight Controls (MFC) Lessons}

\begin{tabular}{|c|c|}
\hline Problem Description & Lesson \\
\hline $\begin{array}{l}\text { RSB PDU gearbox discrepancies: gear } \\
\text { scuffing, dark/contaminated/low oil level. }\end{array}$ & $\begin{array}{l}\text { Perform periodic inspections on isolated fluid cavities that } \\
\text { normally are not checked/sampled and are not continually } \\
\text { filtered, e.g., gearboxes. }\end{array}$ \\
\hline $\begin{array}{l}\text { RSB and BF actuators internal grease } \\
\text { degradation (Braycote 601) }\end{array}$ & $\begin{array}{l}\text { Utilize grease with extreme pressure (EP) additives } \\
\text { necessary for efficient boundary lubrication, better out- } \\
\text { gassing qualities, more stable base oil, corrosion-inhibitors } \\
\text { and improved properties against physical separation and } \\
\text { chemical breakdown. }\end{array}$ \\
\hline $\begin{array}{l}\text { Body Flap PDU internal leakage. } \\
\text { GEARBOX }\end{array}$ & $\begin{array}{l}\text { Assure correct alignment of interfacing seals and close- } \\
\text { tolerance components to prevent leakage, e.g., transfer tubes. } \\
\text { Build special alignment tooling if necessary. } \\
\text { components with no available insight post- assembly. } \\
\text { Conduct post-assembly leakage tests, particularly of internal } \\
\text { such as gearboxes. }\end{array}$ \\
\hline
\end{tabular}




\section{Main Propulsion System (MPS) Lessons}

\section{MPS Subsystem Overview:}

- Consists of the ET, Orbiter MPS, and Space Shuttle Main Engines (SSMEs).

- Extensive GSE also exists to service, monitor, and maintain these elements.

- Tasked with storage, conditioning, distribution, and combustion of cryogenic LH2 and LO2 propellants to provide first and second stage thrust for achieving orbital velocity.

\section{Selected Problems and Lessons:}

\section{- LH2 feedline flowliner cracks.}

- Fully characterize the environment, especially across element interfaces where relatively little may be known.

- Unintended consequences of fluid/acoustic environment, untested during certification.

- Avoid use of stamped flowliner slots, favoring machining if required at all, especially where debris liberation is hazardous.

- Proved success of “inspect and fly" methodology.

\section{- Flow control valve poppet break.}

- Even structure with very high natural frequencies can be excited with acoustic inputs.

- Inspection methods need validation by complementary NDE, especially when cracks are very tight due to material properties and/or driving environment.

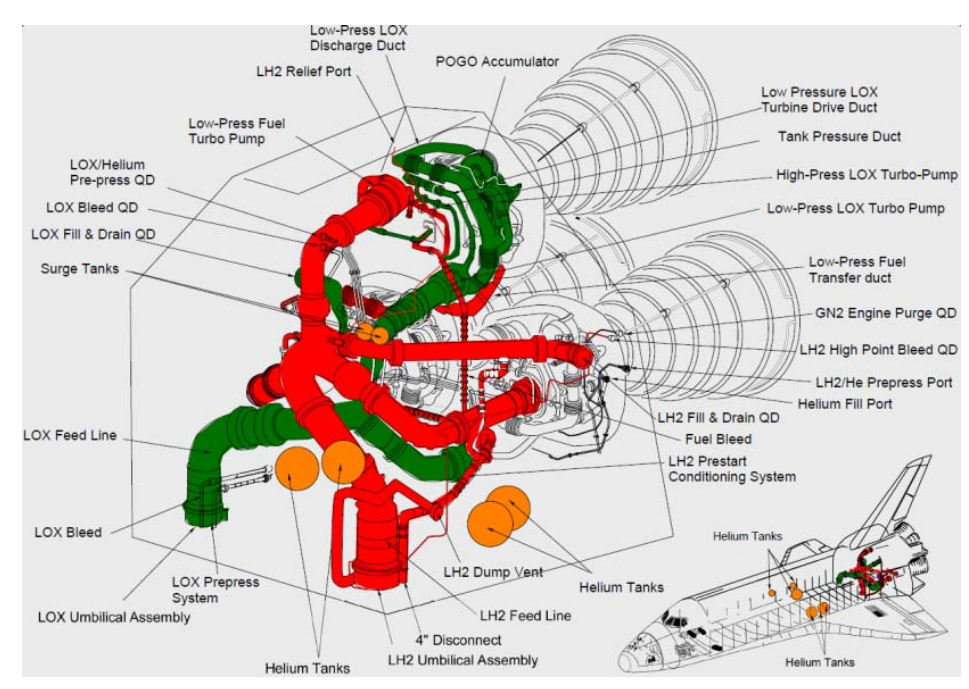

MPS Hardware in the Orbiter Aft Compartment

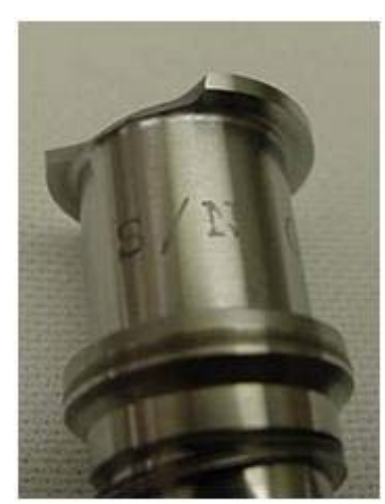

STS-126 broken FCV poppet 


\section{Main Propulsion System (MPS) Lessons}

\begin{tabular}{l|l} 
Problem Description & Lesson \\
\hline LO2 feedline BSTRA ball cracks. & $\begin{array}{r}\text { Casting process can cause voids/inclusions in the parent material, leading } \\
\text { to thermally-induced crack formation during subsequent steps in the } \\
\text { manufacturing process or while in service. The HIP manufacturing } \\
\text { technique can reduce or eliminate voids in the cast material as it cools. }\end{array}$ \\
\hline $\begin{array}{l}\text { Position indicator mounting location. } \\
\text { COPV limited life due to stress } \\
\text { rupture. }\end{array}$ & $\begin{array}{l}\text { An inadequate acceptance testing and inspection process failed to detect } \\
\text { possible. }\end{array}$ \\
\hline $\begin{array}{l}\text { Valve position indicators should be installed downstream of the propellant } \\
\text { valve element rather than upstream at the actuator or in the drive train. }\end{array}$ \\
\hline $\begin{array}{l}\text { Engine cutoff system investigation. } \\
\text { similarity to other hardware in a }\end{array}$
\end{tabular}




\section{Main Propulsion System (MPS) Lessons}

\begin{tabular}{|c|c|}
\hline Problem Description & Lesson \\
\hline Oxygen material compatibility. & $\begin{array}{l}\text { Use of Inconel and Monel was determined to be preferable to stainless } \\
\text { steel based on the reduced propensity to ignite upon particle impact. } \\
\text { Testing should always be performed in a representative GO2 environment } \\
\text { to ensure that design sensitivities are identified early. } \\
\text { pareful consideration on use aluminum or aluminum alloys for piece- } \\
\text { parts that experience relative motion in a GO2 or LO2 system. }\end{array}$ \\
\hline $\begin{array}{l}\text { Gaseous helium check valve } \\
\text { poppet jamming . }\end{array}$ & $\begin{array}{l}\text { Careful attention should be paid to the Length-to-Diameter (L/D) ratio, } \\
\text { radial clearances, and material selection when designing a sliding } \\
\text { interface between valve piece-parts. } \\
\text { Perform representative testing, including high flow demand. }\end{array}$ \\
\hline $\begin{array}{l}\text { Sharp edges and corners on } \\
\text { component piece-parts. }\end{array}$ & $\begin{array}{l}\text { Use generous radii at edges along sliding surfaces, at neck-downs, and on } \\
\text { internal corner to prevent binding/jamming and reduce stress } \\
\text { concentrations. }\end{array}$ \\
\hline $\begin{array}{l}\text { Pre-valve main seal cracking due to } \\
\text { slamming. }\end{array}$ & - Design control preferred over operational control. \\
\hline $\begin{array}{l}\text { Potential for inadequate initial } \\
\text { certification and of program } \\
\text { requirements "creep". }\end{array}$ & $\begin{array}{l}\text { Periodically perform a review of environments for impact on hardware } \\
\text { certification. } \\
\text { Use field and flight failure records as a guide. }\end{array}$ \\
\hline $\begin{array}{l}\text { Designed-in features or analytical } \\
\text { margin are frequently not certified } \\
\text { by test. }\end{array}$ & $\begin{array}{l}\text { Perform burst testing, verification of redundancy, or operation with off- } \\
\text { nominal inputs as required to verify design. }\end{array}$ \\
\hline
\end{tabular}




\section{OMS and RCS Lessons}

\section{OMS/RCS Subsystem Overview:}

- Pressure fed hypergolic propulsion system using monomethylhydrazine $(\mathrm{MMH})$ as the fuel and nitrogen tetroxide (NTO or N2O4) as the oxidizer.

- OMS provides orbit altitude adjustments for the space shuttle vehicle during the orbit phase, orbit insertion after ascent phase (OMS-2 burn), and the deorbit retrograde burn for the entry phase of flight.

- RCS is located in the two OMS pods and the forward module of the vehicle.

$\checkmark$ Provides the shuttle with orbit attitude control using multiple thrusters and entry control until aero surfaces can provide sufficient control authority for the shuttle.

\section{Selected Problems and Lessons:}

- PRCS Pilot Operated Valve fuel valve seal extrusion.

A properly maintained hypergolic system can mitigate or nearly eliminate nitrate related ground and in-flight failures.

- Need integrated hardware qualification testing with propellant, moisture and time exposure.

- Implement preventative maintenance schedule to minimize inflight failures by flushing all thruster valves periodically.

Implement thruster chamber moisture control during ground operations.

- Reduce low-level oxidizer leakage at the poppet/seat interface.

Improve the corrosion resistance of materials at the poppet/seat interface.

- Minimize contact area between mating parts/surfaces to decrease potential nitrate-related stiction.

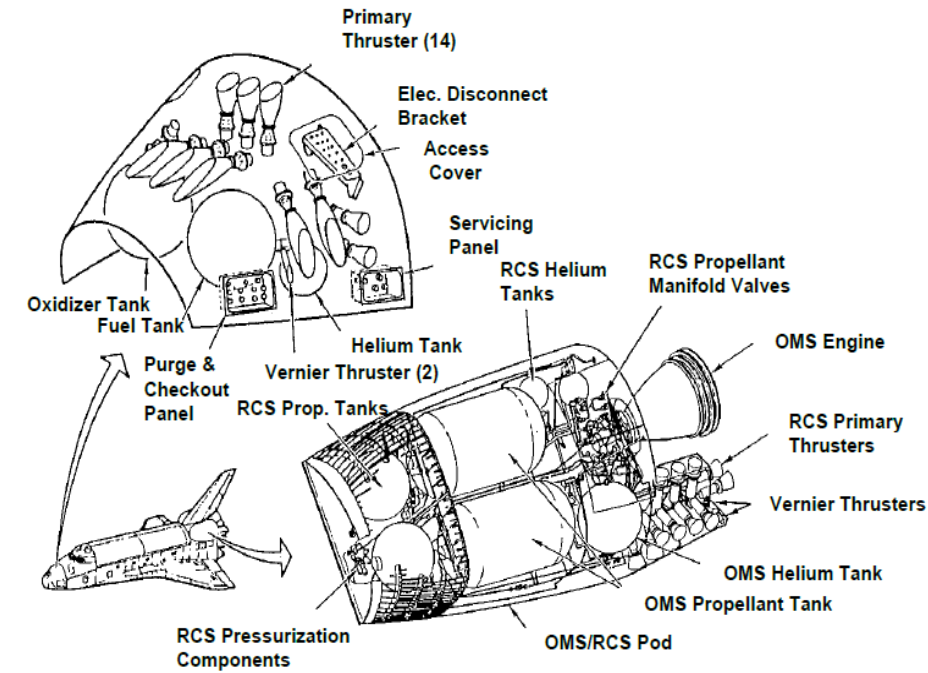

Forward RCS Module and OMS/RCS pods

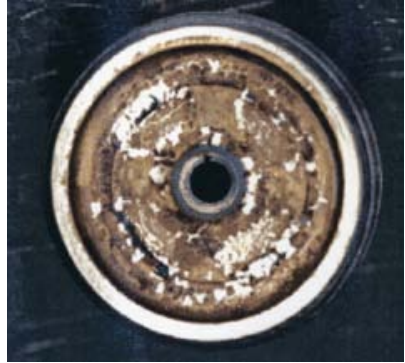

Iron nitrate on RCS POV pilot seat assembly 


\section{OMS and RCS Lessons}

\begin{tabular}{|c|c|}
\hline Problem Description & Lesson \\
\hline $\begin{array}{l}\text { PRCS Pilot Operated Valve fuel valve } \\
\text { seal extrusion. }\end{array}$ & $\begin{array}{l}\text { Thruster chamber moisture control hardware needs to provide sufficient } \\
\text { ventilation of oxidizer vapor through use of a purge system. } \\
\text { (UTPA), can bring unintended consequences. } \\
\text { Sometimes configuration changes, e.g., Universal Throat Plug Assembly } \\
\text { Thruster valve leak rate tolerances should be small. } \\
\text { trace as part of screening method. } \\
\text { Significant benefit of establishing a dedicated team (i.e., Tiger team) to find } \\
\text { root cause. }\end{array}$ \\
\hline $\begin{array}{l}\text { PRCS combustion instability. } \\
\text { STS-68 POV Extruded PTFE (Teflon) }\end{array}$ & $\begin{array}{l}\text { Although generally stable, instabilities were induced when helium bubbles } \\
\text { injected into the fuel stream (propellant saturated with ullage). } \\
\text { - Add stability screening test to thruster hot-fire ATP. } \\
\text { - Add wire wrap as protection for thruster instability. }\end{array}$ \\
\hline $\begin{array}{l}\text { FORP and Pc sense tube burn through } \\
\text { resulted in near catastrophic failure on } \\
\text { STS-51. }\end{array}$ & $\begin{array}{l}\text { - Improve Pc tube design, e.g., avoid “S” shape or increase tube thickness. } \\
\text { - Develop Pc tube flushing schedule to remove FORP. } \\
\text { understood and covered by qualification testing. Rather, inhibit and } \\
\text { reprioritize thruster unless needed as a last resort. } \\
\text { combustion and more FORP formation. }\end{array}$ \\
\hline
\end{tabular}




\section{OMS and RCS Lessons}

\begin{tabular}{l|l} 
Problem Description & Lesson \\
\hline $\begin{array}{l}\text { Vernier thruster reboost results in } \\
\text { valve overtemperature. }\end{array}$ & $\begin{array}{l}\text { Restrict vernier usage to specific reboost duty cycles. Develop go-no-go } \\
\text { duty cycle criteria for long duration reboost requirements. }\end{array}$ \\
\hline $\begin{array}{l}\text { Primary RCS thruster L1L injector } \\
\text { failure in ground test. }\end{array}$ & $\begin{array}{l}\text { Avoid the unique set of ground test conditions that can lead to intra- } \\
\text { manifold explosions such as: leaking thruster valves, leak duration, } \\
\text { horizontal configuration, ambient pressure and thermal conditions. }\end{array}$ \\
\hline $\begin{array}{l}\text { Thrust chamber chips (R-512 } \\
\text { discilicide coating mechanically } \\
\text { induced spalling). }\end{array}$ & $\begin{array}{l}\text { Perform periodic inspections and track growth of known chips. } \\
\text { Characterize chips and develop acceptance rationale such that thruster } \\
\text { nozzles do not need to be R\&R for every chip. Columbium nozzles with } \\
\text { disilicide coating is more robust than initially understood. }\end{array}$ \\
\hline $\begin{array}{l}\text { OMS quantity gauging fuel probes } \\
\text { problems. }\end{array}$ & $\begin{array}{l}\text { Have alternate/redundant quantity gauging methods, e.g., ground loading } \\
\text { gauging, in-flight engine firing time integration, PVT calculation. } \\
\text { Manufacturer's expertise was with capacitor gauging sensors and not } \\
\text { with complex electronic systems (totalizer). Recognize manufacturers } \\
\text { expertise and limitations. Need right expertise for right technology. }\end{array}$ \\
\hline $\begin{array}{l}\text { More thorough acceptance test to screen out deficiencies. } \\
\text { High ground processing timeline, } \\
\text { cost, hazards (hot R\&R, fire), } \\
\text { supportability and obsolescence. }\end{array}$ & $\begin{array}{l}\text { Closely track removal rates, repair times, spares counts, limited life } \\
\text { hardware, and status of repair agencies. }\end{array}$ \\
$\begin{array}{l}\text { Implement Integrated vehicle Health Monitoring system (IVHM). } \\
\text { Relocate system components to the pod outer mold line and/or add quick } \\
\text { component access doors to avoid the need to remove the whole pod for } \\
\text { troubleshooting. }\end{array}$ & Few area heaters are far easier for ground checkout.
\end{tabular}




\section{Fuel Cell and PRSD Lessons}

\section{Fuel Cell/PRSD Subsystem Overview:}

- 3fuel cell powerplants on each Orbiter capable of providing 2$10 \mathrm{~kW}$ nominal power (16 kW max) with voltage regulation between 27.5 - 32.5 VDC.

- Low temperature alkaline fuel cell (AFC) power plant consists of a 96-cell stack and an accessory section.

- Reactants (oxygen and hydrogen) are stored in four or five Power Reactant Storage Distribution (PRSD) tanks, also located in the mid body of the Orbiter.

\section{Selected Problems and Lessons:}

- STS-2 FC1 shutdown following H2 pump/water separator failure and FC flooding.

- Bus-tying the suspicious fuel cell with a healthy fuel cell is the method for monitoring performance of the suspect fuel cell when one fuel cell picks up the load from another.

For vital systems, redundancy in monitoring the system's health is as important as it is in the system itself.

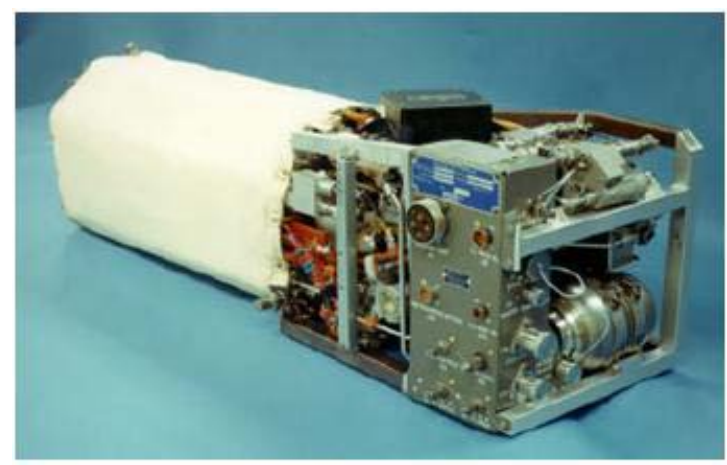

Orbiter Alkaline Fuel Cell Powerplant

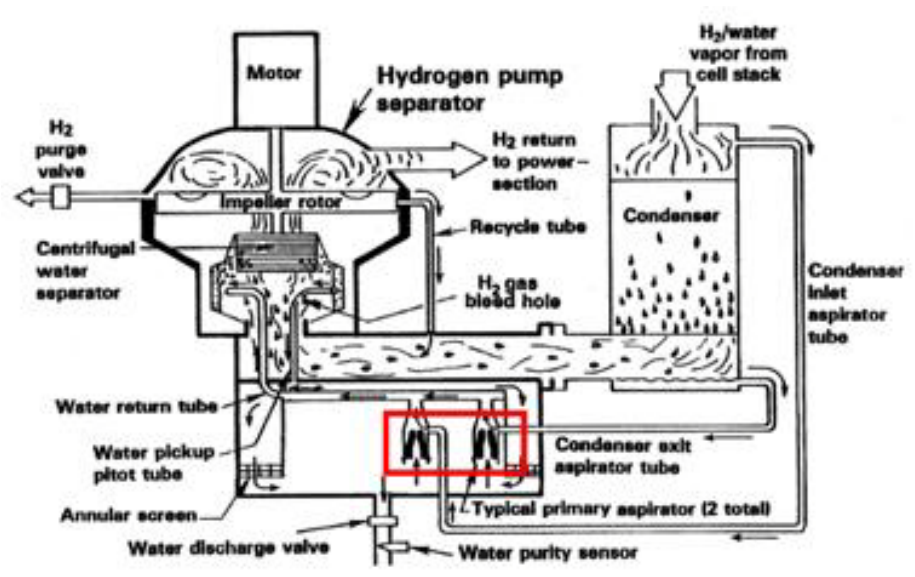

Fuel Cell Hydrogen Pump Separator; aspirator tubes highlighted in red 


\section{Fuel Cell and PRSD Lessons}

\begin{tabular}{|c|c|}
\hline Problem Description & Lesson \\
\hline $\begin{array}{l}\text { STS-4 condenser exit temperature } \\
\text { downward shift. }\end{array}$ & $\begin{array}{l}\text { Validate all instrumentation at maximum loads by running the fuel cells at } \\
\text { high power for approximately 30min shortly after fuel cell activation. }\end{array}$ \\
\hline $\begin{array}{l}\text { STS-43 post-landing: fuel cells left } \\
\text { on bus without water removal } \\
\text { capabilities. }\end{array}$ & $\begin{array}{l}\text { Operation timelines and procedures must be developed, executed and } \\
\text { verified to avoid potential permanent damages to systems. } \\
\text { Cells can provide power even when Fuel Cell is off. }\end{array}$ \\
\hline $\begin{array}{l}\text { Fuel Cell shutdown/restart in mid- } \\
\text { flight. }\end{array}$ & $\begin{array}{l}\text { Redundant power systems need to be designed and proven in a space } \\
\text { environment, i.e., shutdown/restart capability. }\end{array}$ \\
\hline $\begin{array}{l}\text { STS-83 FC shutdown due to } \\
\text { perceived crossover. }\end{array}$ & $\begin{array}{l}\text { When vital instrumentation has a history of being erratic, a redundant } \\
\text { measurement (such as FCMS data) must be available to rule out failures. } \\
\text { perform safing procedures and eliminate the risk of an unplanned failure. }\end{array}$ \\
\hline $\begin{array}{l}\text { Port plugging (inability to clear inerts } \\
\text { due to cell corrosion buildup). }\end{array}$ & $\begin{array}{l}\text { All materials within the system need to be indentified for potential particles } \\
\text { release and must include Failure Mode and Effects Analysis. } \\
\text { carbonate formation inside O2/H2 inlet/outlet ports can arise from } \\
\text { carbonation of fiberglass/epoxy FC frame. } \\
\text { Importance of maintaining system cleanliness. } \\
\text { and purges are performed when necessary. }\end{array}$ \\
\hline $\begin{array}{l}\text { STS-115 loss of phase in coolant } \\
\text { pump and H2 pump. }\end{array}$ & $\begin{array}{l}\text { Three-phase electrical motors need to be evaluated and tested for being } \\
\text { able to operate in two-phase. } \\
22\end{array}$ \\
\hline
\end{tabular}




\section{Fuel Cell and PRSD Lessons}

\begin{tabular}{|c|c|}
\hline Problem Description & Lesson \\
\hline ze possibility. & $\begin{array}{l}\text { Operating environments need to be identified, implemented in design, } \\
\text { performed and evaluated. } \\
\text { problems may also arise which might require re-evaluation of risks. }\end{array}$ \\
\hline ivity. & $\begin{array}{l}\text { Unusual sensor activity can indicate a trend toward failure of the H2 } \\
\text { pump motor, and thus a subsequent loss of the fuel cell. } \\
\text { make sure that all causes for output variations are understood and } \\
\text { procedures are in place for filtering out actual failure indications. }\end{array}$ \\
\hline staining heater & $\begin{array}{l}\text { Effects of thermal environments must be included in design and } \\
\text { demonstrated by testing. } \\
\text { sometimes require heating to return to operating temperature. } \\
\text { When the fuel cells are performing on the low end of their certification } \\
\text { (2kW), sustaining heater cycles become a necessary component for } \\
\text { operation: if they fail ON, the fuel cell needs to be safed immediately if } \\
\text { the coolant system malfunctions in any way; if they fail OFF, the fuel } \\
\text { cell load needs to be increased to maintain temperature, resulting in a } \\
\text { cryogenic margin impact. }\end{array}$ \\
\hline $\begin{array}{l}\text { Multiple O2/H2 flowmeter erratic } \\
\text { readings and failures (shifts in } \\
\text { calibration, zero output, full-scale } \\
\text { output, constant output). }\end{array}$ & $\begin{array}{l}\text { Flow path must be external to the electronic \& instrumentation housing. } \\
\text { component outweighs the benefit. } \\
\text { So long as a flowmeter still accurately indicates a purge, it will also } \\
\text { accurately indicate a significant leak. }\end{array}$ \\
\hline
\end{tabular}




\section{EPD\&C, Wiring and Insulation Lessons}

\section{Subsystem Overview:}

- Electrical Power Distribution and Control (EPD\&C) subsystem consists of a 3-bus system that distributes electrical power ( $24 \mathrm{~V}$ to $32 \mathrm{~V}$ ) from the fuels cells to the forward, mid, and aft sections of the Orbiter.

- EPD\&C system also includes three $120 \mathrm{~V}, 400 \mathrm{~Hz}, 3-$ phase, alternating current (AC) power busses, generated by sets of 750volt-ampere (VA) inverters from the main busses.

- Electrical Wiring and Insulation (EW\&I) is made up of all electrical wiring and connectors external to subsystem boxes.

- Approximately 600 harnesses, 7,000 connectors, 120,000 wire segments and 228 miles of wire.

\section{Selected Problems and Lessons:}

- STS-93 wire short description:

- Short circuit in the AC system during ascent caused the loss of 2 main engine controllers.

- Post flight investigation found the cause to be a damaged wire with an exposed conductor that contacted a nearby burred screw head.

- As a result of the inspections, many other incidents were found of damaged wires and improperly protected wire harness.
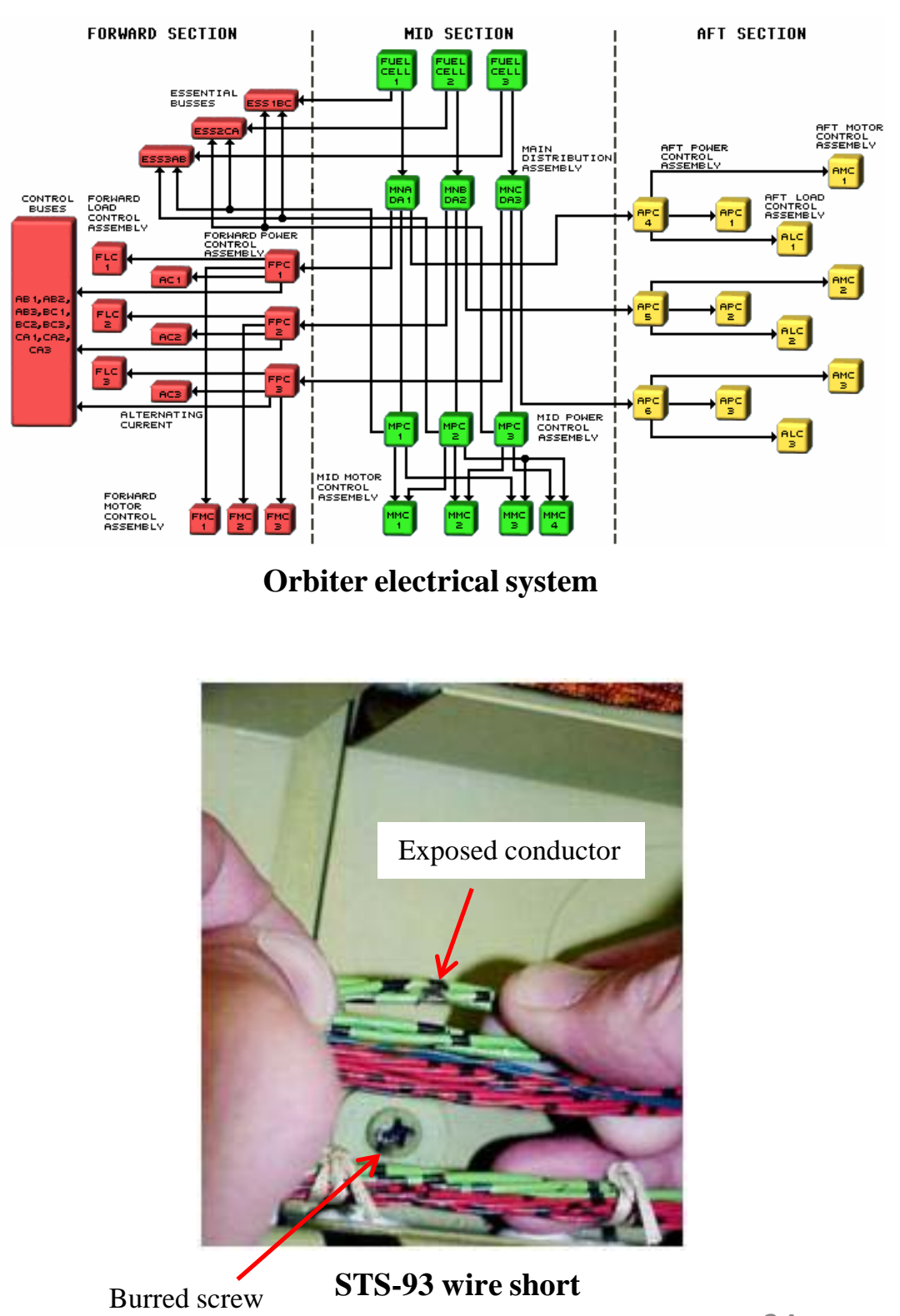


\section{EPDC, Wiring and Insulation Lessons}

\section{Selected Problems and Lessons: (Continued)}

- STS-93 wire short (Lessons):

- Ground maintenance and vehicle modifications can cause damage like burrs on screw heads that lead to later wire damage.

Closeout inspections did not focus on inspecting the wiring.

- Use auxiliary lighting and mirrors to inspect all accessible wiring.

- Formalized and more clearly defined wire inspection criteria and processes. Perform periodic wiring inspections; particularly inspect for previously undetected wiring discrepancies.

Any primary wire insulation damage is unacceptable regardless of whether conductor is exposed or not.

Separate critical redundant wire runs and/or install barrier materials to protect against the effects of arc tracking.

- Widespread use of chafe protection greatly reduced wire damage.

Enhanced workforce awareness and training is paramount in ensuring the health of electrical wiring.

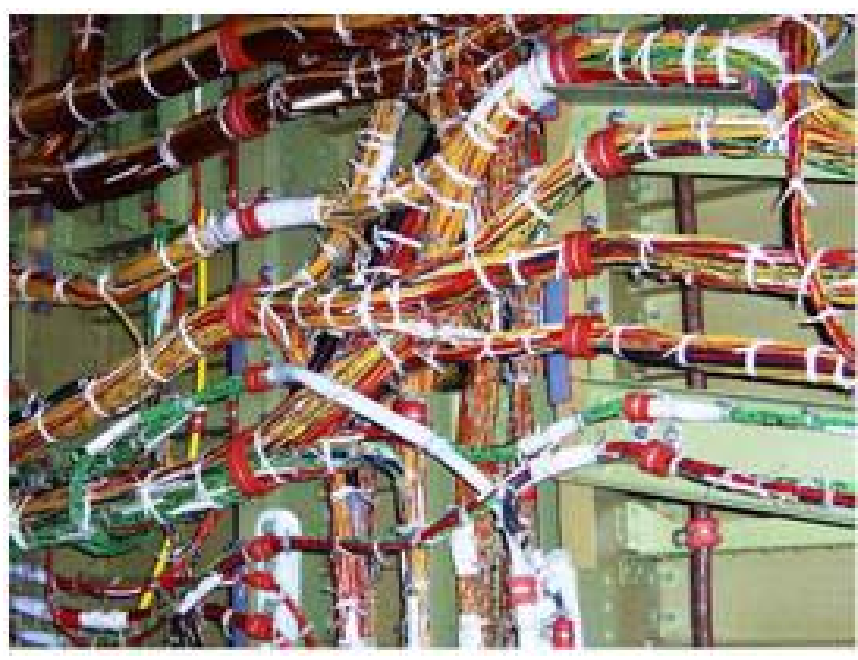

Orbiter wiring

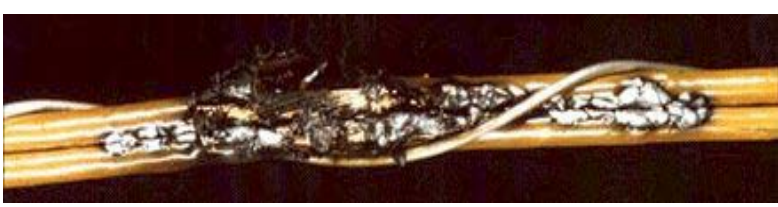

Example of arc tracking 


\section{EPDC Wiring and Insulation Lessons}

\begin{tabular}{|c|c|}
\hline Problem Description & Lesson \\
\hline $\begin{array}{l}\text { Vehicle wire damage due to } \\
\text { ground maintenance activity } \\
\text { (mechanically induced damage). }\end{array}$ & $\begin{array}{l}\text { Important to perform specific detailed closeout inspection after work on cables or } \\
\text { connectors. } \\
\text { - Wiring is easily damaged by nearby work activity. } \\
\text { - Training of personnel is critical both to prevent damage and to detect damage. } \\
\text { - Wire chafe protection is important. }\end{array}$ \\
\hline STS-4 Heater fuse failure. & $\begin{array}{l}\text { Repetitive thermal cycles on a fuse can cause it to mechanically open } \\
\text { Space and usage environments must be considered for fuse de-rating. }\end{array}$ \\
\hline Circuit breaker problems. & $\begin{array}{l}\text { Cycling circuit breakers recovers function. } \\
\text { - Debris is created from internal wear on circuit breakers. } \\
\text { Avoid use of CBs as power switches and redundant controls. }\end{array}$ \\
\hline Personnel switch bumps. & $\begin{array}{l}\text { Redundancy of controls and inhibits important for critical functions. } \\
\text { Utilize switch guards. }\end{array}$ \\
\hline Lightning monitoring system. & $\begin{array}{l}\text { Low frequency bus voltage monitoring systems are inadequate for detecting } \\
\text { lightning transients on vehicle power busses. } \\
\text { should be higher than lowest resonant frequency of vehicle power bus. } \\
\text { In order to detect lightning transients, monitoring system frequency response } \\
\text { Low level signals easily couple onto bus from distant strikes, several miles away. } \\
\text { - Use pulse energy (vs. voltage magnitude) to assess damage (Wunsch-Bell). }\end{array}$ \\
\hline
\end{tabular}




\section{Pyrotechnics Lessons}

\section{Subsystem Overview:}

- Explosive devices that contain energetic mixtures of fuel and oxidizer compounds that when activated by electrical or mechanical initiation converts chemical energy to mechanical energy.

- 50 Government Furnished Equipment (GFE) pyrotechnics devices have been certified for human spaceflight by JSC

- These include the NASA Standard Initiator (NSI), NASA Standard Detonator (NSD), several types of power pressure cartridges, mild detonating fuse and detonating cords, shear bolts, explosive bolts and frangible nuts, guillotines, reefing line cutters and other devices.

- About 140 NSIs flown on each Shuttle flight.

- Over 13,750 NSI fired during flight on the shuttle vehicles without a failure, with a reliability of 0.9999 at a confidence level of $95 \%$.

\section{Selected Problems and Lessons:}

- STS-8 ejected Nose Landing Gear Extension Thruster.

- Verify that hardware design and qualification testing account for all potential flight conditions.

- Never assume contained air pressure is available as an assist to pyrotechnic performance.

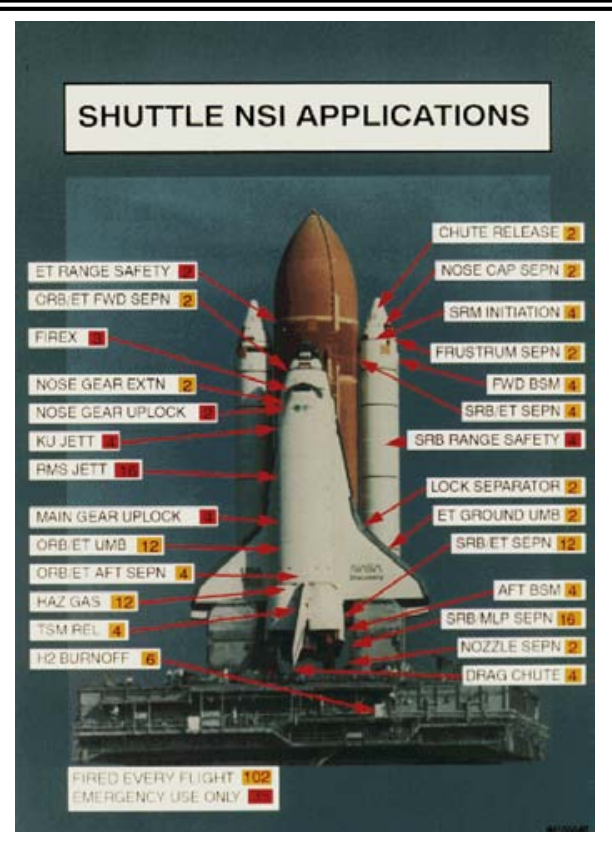

Space Shuttle Pyrotechnic Devices

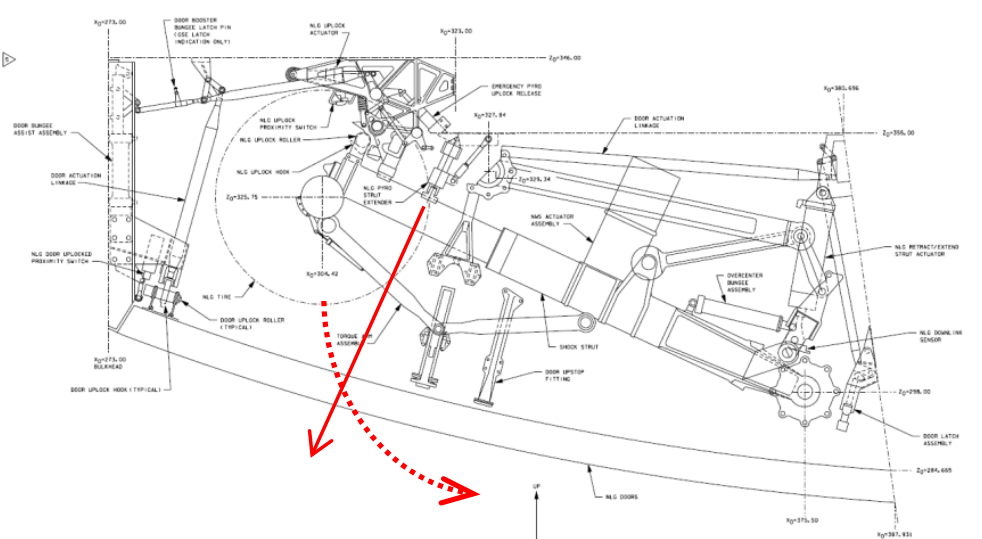

NLG extension thruster and likely trajectory of piston and wheel on STS-8 landing 


\section{Pyrotechnics Lessons}

\begin{tabular}{|c|c|}
\hline Problem Description & Lesson \\
\hline $31 \frac{1}{2}$ inch frangible nut skew firing. & $\begin{array}{l}\text { Be sensitive to the firing skew present in all redundant pyrotechnic } \\
\text { systems. }\end{array}$ \\
\hline Propellant powder deterioration. & $\begin{array}{l}\text { Changes in the manufacturing processes had occurred that were not } \\
\text { evident during the commercial certification of the material. }\end{array}$ \\
\hline $\begin{array}{l}\text { Inconel alloy } 718 \text { became stronger } \\
\text { and harder to break. }\end{array}$ & $\begin{array}{l}\text { Be aware of raw material processing "refinements" over time which } \\
\text { occur to satisfy other primary material users. Need for control of material } \\
\text { grain sizes (e.g., roll milling). } \\
\text { particularly in applications that are sensitive like separation systems. }\end{array}$ \\
\hline Pyro- & $\begin{array}{l}\text { Debris in bore and/or manufacturing dimensional variations can cause } \\
\text { pyrovalve to not properly seal after firing/actuation. } \\
\text { The NSI is an initiator and should not be used as a pressure cartridge, } \\
\text { i.e., use NSI plus booster pressure cartridge. }\end{array}$ \\
\hline
\end{tabular}




\section{Summary/Conclusions}

A selected few "key" lessons in Orbiter Power and Propulsion subsystems were presented.

- Subsystems included: APU, Hydraulics, WSB, Mechanical Flight Controls, MPS, OMS/RCS, Fuel Cells/PRSC, EPD\&C, Electrical Wiring and Insulation and Pyrotechnics.

- These lessons cover the nearly 40 year history of the Space Shuttle Program.

There are several common lessons across subsystems. These include:

- Design solutions are preferred over continuous maintenance. However, verification of the validity of operational limitations is preferred over re-design, if proven acceptable.

- Importance of a full understanding of the operational environment.

- Importance of a thorough and integrated mission-representative qualification test program.

System improvements, corrective actions for other problems, process changes, and/or mission requirement changes can bring unintended consequences or unexpected sensitivities.

- Implement a robust program-wide contamination control plan.

Importance of a robust and thorough Corrective Action process that avoids extensive latitude for accepting repeated failures without preventive corrective actions.

- Important to design critical systems to be fail-safe and that redundant elements are independent.

Establish periodic and preventative maintenance.

Establishing a fleet leader test program.

Trending of hardware operational flight and ground test data to uncover any out-of-family or degraded performance, well before they become critical.

Always verify the system integrity after any intrusive work is performed on the vehicle.

- Design systems for ease of leak checking and operational verification.

It is the hope of the authors that these lessons are useful to future space programs. 
Backup 